\title{
AVALIAÇÃO DO PAPEL DOS HORMÔNIOS SEXUAIS FEMININOS EM MODELO MURINO DE ASMA EXPERIMENTAL
}

Tese apresentada ao Programa de PósGraduação em Farmacologia do Instituto de Ciências Biomédicas da Universidade de São Paulo, para obtenção do Título de Doutor em Ciências 


\section{AVALIAÇÃO DO PAPEL DOS HORMÔNIOS SEXUAIS FEMININOS EM MODELO MURINO DE ASMA EXPERIMENTAL}

Tese apresentada ao Programa de PósGraduação em Farmacologia do Instituto de Ciências Biomédicas da Universidade de São Paulo, para obtenção do Título de Doutor em Ciências

Área de concentração: Farmacologia

Orientador: Prof. Dr. Wothan Tavares de Lima

Versão corrigida. A versão original eletrônica encontra-se disponível tanto na Biblioteca do ICB quanto na Biblioteca Digital de Teses e Dissertações da USP (BDTD) 
DADOS DE CATALOGAÇÃO NA PUBLICAÇÃO (CIP)

Serviço de Biblioteca e Informação Biomédica do

Instituto de Ciências Biomédicas da Universidade de São Paulo

(c) reprodução total

Accetturi, Beatriz Golegã.

Avaliação do papel dos hormônios sexuais femininos em modelo murino de asma experimental / Beatriz Golegã Accetturi. -- São Paulo, 2014.

Orientador: Prof. Dr. Wothan Tavares de Lima.

Tese (Doutorado) - Universidade de São Paulo. Instituto de Ciências Biomédicas. Departamento de Farmacologia. Área de concentração: Farmacologia. Linha de pesquisa: Fisiopatologia da inflamação experimental.

Versão do título para o inglês: Evaluation of the role of female sex hormones in a murine model of experimental asthma.

1. Hormônios sexuais femininos 2. Asma 3. Reatividade das vias aéreas 4. Mecânica pulmonar 5. Camundongos I. Lima, Prof. Dr. Wothan Tavares de II. Universidade de São Paulo. Instituto de Ciências Biomédicas. Programa de Pós-Graduação em Farmacologia III. Título. 


\title{
UNIVERSIDADE DE SÃO PAULO \\ INSTITUTO DE CIÊNCIAS BIOMÉDICAS
}

\begin{abstract}
Candidato(a): $\quad$ Beatriz Golegã Accetturi.
Título da Tese:

Avaliação do papel dos hormônios sexuais femininos em modelo murino de asma experimental.
\end{abstract}

Orientador(a):

Prof. Dr. Wothan Tavares de Lima.

A Comissão Julgadora dos trabalhos de Defesa da Tese de Doutorado, em sessão

pública realizada a

( ) Aprovado(a) I.

1.

( ) Reprovado(a)

$\begin{array}{ll}\text { Examinador(a): } & \begin{array}{l}\text { Assinatura: } \\ \text { Nome: } \\ \text { Instituição: }\end{array} \\ \text { Examinador(a): } & \begin{array}{l}\text { Assinatura: } \\ \text { Nome: } \\ \text { Instituição: }\end{array} \\ \text { Examinador(a): } & \begin{array}{l}\text { Assinatura: } \\ \text { Nome: } \\ \text { Instituição: }\end{array} \\ \text { Assinatura: } \\ \text { Presidente: } \\ \begin{array}{l}\text { Instituição: } \\ \text { Assinatura: } \\ \text { Nome: } \\ \text { Instituição: }\end{array}\end{array}$ 


\section{Certificado}

Certificamos que o protocolo registrado sob $\mathrm{n}^{\circ} 118$ nas fls. 92 do livro 02 para uso de animais em experimentação, sob a responsabilidade do $\operatorname{Prof(a)} \operatorname{Dr}(\mathrm{a})$ Wothan Tavares de Lima, Coordenador(a) da Linha de pesquisa Estudo do envolvimento dos hormônios sexuais femininos no estudo funcional de células dendritricas, na liberação de medidadores inflamatórios e na funçăo pulmonar do qual participam o(s) alunos Beatriz Golegå Accetturi, Ana Paula Ligeiro de Oliveira, Jean Pierre Schatzman Perón, estả de acordo com os Princípios Éticos de Experimentação Animal adotado pela Sociedade Brasileira de Ciência de Animais de Laboratório (SBCAL) e foi aprovado pela COMISSÃO DE ÉTICA NO USO DE ANIMAIS (CEUA) em 23.11.2010, com validade de 3 anos.

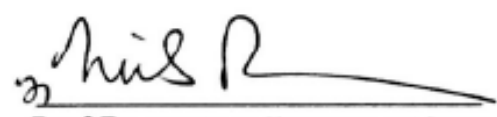

Prof.Dr.Wothan TAVARES DE LIMA Coordenador CEUA - ICB/USP
São Paulo, 25 de novembro de 2010.

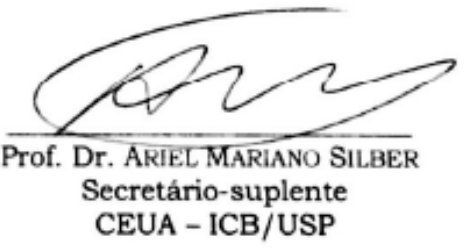




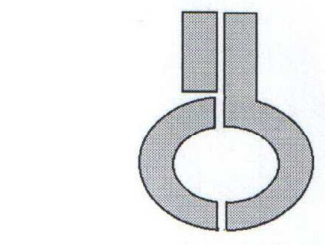

UNIVERSIDADE DE SÃo PAULO

INSTITUTO DE CIÊNCIAS BIOMÉDICAS

Cidade Universitária "Armando de Salles Oliveira"

Av. Prof. Lineu Prestes, 2415 - cep. 05508-000 São Paulo, SP - Brasil

Telefone :(55) (011) 3091.7733 e-mail: cep@icb.usp.br

Of.CEUA. 122.13

São Paulo, 05 de novembro de 2013.

REF.: Protocolo ${ }^{\circ}$ 118/2010.

" Avaliação do papel dos hormônios sexuais femininos em modelo murino de asma experimental"

Prezado Professor,

Informo que a sua licença para uso de animais em experimentação, constante no protocolo em epígrafe, foi prorrogada até 23.11.2016.

Reitero que havendo alteração de metodologia e inserção de novos alunos ao projeto de pesquisa vinculado à referida licença a CEUA/ICB deverá ser informada.

Cordialmente,

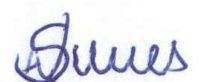

Prof. Dr. ANDERSON DE SÁ NunES

Vice- Coordenador - CEUA-ICB/ /USP

Ilmo.Sr.

Prof Dr. Wothan Tavares de Lima

Departamento de Farmacologia

Instituto de Ciências Biomédicas - USP 
Aos meus pais, Verônica e Silvério pelo amor e incentivo, pelo exemplo de coragem e sabedoria, minha eterna gratidão

Aos meus irmãos Fernanda, Rafael e Maria Alice, pela amizade, amor e companheirismo sempre
À Marly e Vitor, mãe e pai "postiços" que me acolheram em sua família

Ao Denis, anjo que Deus colocou na minha vida, parceiro e grande incentivador das minhas conquistas 


\section{AGRADECIMENTOS}

A Deus, pela minha existência e por permitir que eu seja merecedora desta vitória

Ao meu orientador, professor Dr. Wothan Tavares de Lima, pela oportunidade oferecida, pela confiança e por ter me guiado desde os primeiros passos nesta jornada

Ao professor Ricardo pelos ensinamentos, amizade e auxílio

À Ana Paula e Adriana por terem sido sempre meu referencial como pesquisadoras, seres humanos e amigas

Ao Johny e Luana, amigos e parceiros para toda vida. Obrigada pela amizade, pela paciência, pela presteza e auxílio até mesmo nos finais de semana. Vocês foram fundamentais na elaboração deste trabalho

Aos grandes amigos Helô, Jean e Clariana, pela amizade sólida e verdadeira.

Às professoras Iolanda Tibério e Carolina Munhoz pelas valiosas sugestões na banca de qualificação

Ao pessoal do laboratório pela convivência e ajuda.

À Mônica e Camila pelo atendimento prestativo, e à Sandra, pelos cuidados com nossos animais.

Às minhas amigas de trabalho Larissa, Thais, Ritinha, Vanessa França, Vanessa Faria, Lú, Marcinha e Lili pela amizade, paciência e apoio sempre

Aos meus líderes Mônica, Vera, José Dínio, Sílvia e Silvany, pela amizade e compreensão sempre que precisei me ausentar do emprego para finalizar este trabalho

À FAPESP e ao CNPq pelo auxílio financeiro. 
O presente trabalho foi realizado no Laboratório de Fisiopatologia da Inflamação Experimental do Departamento de Farmacologia do Instituto de Ciências Biomédicas da Universidade de São Paulo (ICB/USP), na vigência de auxílios concedidos pela Fundação de Amparo à Pesquisa do Estado de São Paulo (FAPESP), Processo 2010/51997-7 e Conselho Nacional de Desenvolvimento Científico e Tecnológico (CNPq). 


\section{RESUMO}

ACCETTURI, B. G. Avaliação do papel dos hormônios sexuais femininos em modelo murino de asma experimental. 2014. $111 \mathrm{f}$. Tese (Doutorado em Farmacologia) - Instituto de Ciências Biomédicas, Universidade de São Paulo, São Paulo, 2014.

A asma é uma doença inflamatória pulmonar crônica cujo envolvimento do sistema imune e citocinas derivadas dos linfócitos Th2 é bem estabelecido. Os hormônios sexuais femininos (HSF) alteram o curso da asma e parecem interferir com a apresentação de antígenos, com o recrutamento de células inflamatórias para o pulmão, com a produção de mediadores e com a função pulmonar. Levando em consideração que mulheres asmáticas na pós-menopausa podem apresentar piora dos sintomas da asma, neste trabalho investigamos o papel dos HSF na modulação da inflamação pulmonar alérgica experimental previamente instalada. Avaliamos o recrutamento e a mobilização celular para os pulmões, as alterações histológicas dos pulmões, a reatividade das vias aéreas in vitro, a mecânica respiratória e quantificamos citocinas em amostras de explante pulmonar. Numa série paralela de estudos, os animais alérgicos OVx foram submetidos ao tratamento com estrógeno, com progesterona ou ambos e todos os parâmetros também foram avaliados. Os dados obtidos mostraram que a reexposição ao antígeno causou exacerbação da inflamação alérgica pulmonar nos animais alérgicos OVx. Entretanto, estes animais apresentaram valores de reatividade traqueal semelhante ao observado nos animais alérgicos Sham/OVx. O tratamento dos animais alérgicos OVx com estrógeno seguido do re-desafio causou exacerbação adicional da inflamação pulmonar, mas, por outro lado, atenuou a reatividade traqueal e também a mecânica pulmonar. $O$ tratamento com progesterona não alterou o número de células do lavado broncoalveolar e também atenuou a reatividade traqueal e a mecânica pulmonar, apesar destes animais estarem com a produção de muco e colágeno acentuada. $\mathrm{O}$ tratamento com estrógeno em associação com a progesterona atenuou a inflamação pulmonar aos valores encontrados nos animais alérgicos Sham/OVx. Os dados obtidos até o momento permitem sugerir que a carência dos HSF contribui para a exacerbação da inflamação pulmonar alérgica, da reatividade das vias aéreas e da liberação de mediadores inflamatórios. De modo geral, o tratamento com estrógeno ou progesterona modula positivamente a inflamação alérgica pulmonar e negativamente a reatividade das vias aéreas, e o tratamento com ambos os hormônios modula negativamente a inflamação pulmonar. Diante do exposto, nossos estudos apontam para uma resposta inflamatória mediada por diferentes mecanismos inflamatórios, além da possível dissociação entre os efeitos moduladores dos hormônios sexuais femininos sobre a resposta inflamatória, notadamente no recrutamento celular e as alterações de mecânica respiratória.

Palavras-chave: Hormônios sexuais femininos. Asma. Reatividade das vias aéreas. Mecânica pulmonar. Camundongos. 


\begin{abstract}
ACCETTURI, B. G. Evaluation of the role of female sex hormones in a murine model of experimental asthma. 2014. 111 p. Ph. D. Thesis (Pharmacology) - Instituto de Ciências Biomédicas, Universidade de São Paulo, São Paulo, 2014.

Asthma is a chronic inflammatory lung disease, and the involvement of the immune system and Th2 cytokines derived from lymphocytes is well established. Female sex hormones (HSF) alter the course of asthma and appear to interfere with antigen presentation, with the recruitment of inflammatory cells to the lung, with the production of mediators and pulmonary function. Since asthmatic women in pre-menstrual period or post-menopausal may experience worsening of asthma symptoms, we investigated the role of HSF in the modulation of experimental allergic lung inflammation previously installed. We evaluated the recruitment and cell mobilization into the lungs, the histological changes in the lungs, reactivity of the airways and quantify cytokines in samples of lung explants. In a parallel series of studies, allergic OVx animals were subjected to treatment with estrogen, progesterone, or both, and all parameters were also evaluated. The data showed that re-exposure to antigen caused exacerbation of allergic lung inflammation in allergic animals OVx. However, these animals showed values of pulmonary reactivity similar to that observed in allergic animals Sham/OVx. Treatment of allergic OVx animals with estrogen followed by re-challenge caused exacerbated pulmonary inflammation, but on the other hand, attenuated tracheal reactivity and lung mechanics. The progesterone treatment did not alter the number of cells in the bronchoalveolar fluid and also attenuated tracheal reactivity and lung mechanics, though the production of mucus and collagen was increased. Treatment with estrogen in combination with progesterone attenuated lung inflammation to the values found in allergic Sham/OVx. The data suggests that the lack of HSF contributes to exacerbation of allergic lung inflammation, airway reactivity and release of inflammatory mediators. In The treatment with estrogen or progesterone positively modulates the allergic lung inflammation and negative modulates the airways reactivity, and treatment with both hormones negatively modulates airway inflammation. Our studies point to an inflammatory response mediated by different inflammatory mechanisms, beyond the possible dissociation between the modulatory effects of female sex hormones on the inflammatory response, especially cell recruitment and alterations in respiratory mechanics.
\end{abstract}

Keywords: Female sex hormones. Asthma. Airways reactivity. Lung mechanics. Mice. 


\section{LISTA DE FIGURAS}

Figura 1- Envolvimento dos hormônios sexuais femininos na atividade do sistema imune....29

Figura 2- Fotografias do aparelho utilizado para a avaliação da reatividade traqueal .............39

Figura 3- Fotografias do aparelho utilizado para a avaliação da mecânica pulmonar. ............41

Figura 4- Determinação da massa uterina após a remoção dos ovários. ..................................45

Figura 5 - Fotomicrografias das fases do ciclo estral de camundongos fêmeas e de um animal 10 dias após a remoção dos ovários.

Figura 6 - Determinação dos níveis plasmáticos de estradiol e progesterona.

Figura 7 - Efeito da ovariectomia (OVx) sobre o número total de células do LBA 24 h após a última broncoprovocação.

Figura 8 - Efeito da ovariectomia sobre o número de neutrófilos (A), eosinófilos (B) e células mononucleares $(\mathrm{C})$ presentes no LBA 24 h após a última broncoprovocação.

Figura 9 - Infiltrado celular das vias aéreas obtido pela coleta do LBA em aumento de 40x...51

Figura 10 - Efeito da ovariectomia (OVx) sobre o número total de leucócitos circulantes 24 h após a última broncoprovocação.

Figura 11 - Efeito da ovariectomia sobre o número de células mononucleares (a) e polimorfonucleares (b) presentes no sangue e recuperadas 24 hs após a última broncoprovocação.

Figura 12 - Efeito da ovariectomia $(\mathrm{OVx})$ sobre o número total de células da medula óssea 24 h após a última broncoprovocação.

Figura 13 - Fotomicrografias de cortes histológicos de pulmão corados com PAS em aumento de $40 x$

Figura 14 - Infiltrado celular das vias aéreas em aumento de 40x.

Figura 15 - Fotomicrografias de cortes histológicos de pulmão corados com picrossirius.

Figura 16 - Efeito da ovariectomia (OVx) sobre a concentração de corticosterona plasmática.

Figura 17 - Efeito da ovariectomia sobre a reatividade traqueal in vitro 24 h após a última broncoprovocação.

Figura 18 - Efeito da ovariectomia sobre a (A) resistência pulmonar e (B) elastância pulmonar in vivo $24 \mathrm{~h}$ após a última broncoprovocação. 


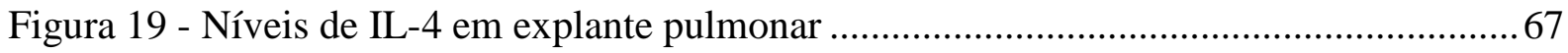

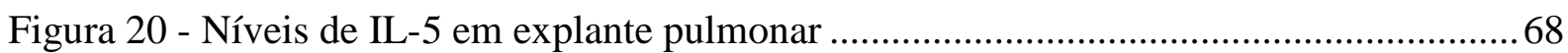

Figura 21 - Níveis de IL-1 $\beta$ em explante pulmonar. ........................................................69

Figura 22 - Níveis de IL-13 em explante pulmonar. ........................................................ 70

Figura 23 - Níveis de TNF- $\alpha$ em explante pulmonar. ........................................................ 71

Figura 24 - Níveis de IL-10 em explante pulmonar. ............................................................. 72

Figura 25 - Níveis de $\mathrm{NO}_{2}$ em explante pulmonar. ............................................................... 73 


\section{LISTA DE ABREVIATURAS E SIGLAS}

ACh - acetilcolina

APCs - células apresentadoras de antígeno

$\mathrm{Ca}^{2+}$ - cálcio

$\mathrm{CO}_{2}$ - gás carbônico

DMEM - Dulbecco's Modified Eagle's Medium

DC - células dendrítica

E - estrógeno

$\mathrm{E}+\mathrm{P}$ - estrógeno associado à progesterona

e-NANC - não-adrenérgico não-colinérgico excitatório

e-NOS - óxido nítrico-sintase endotelial

ERS - elastância pulmonar

$\mathrm{ER} \alpha$ - receptor de estrógeno alfa

ER $\beta$ - receptor de estrógeno beta

HSF - Hormônios sexuais femininos

IgE - Imunoglobulina E

IL-10 - interleucina 10

IL-13 - interleucina 13

IL-1 $\beta$ - interleucina-1beta

IL-4 - Interleucina 4

IL-5 - Interleucina 5

LTh2 - Linfócito T helper 2

i-NANC - não-adrenérgico não-colinérgico inibitório

i-NOS - óxido nítrico-sintase induzida

LBA

NANC - sistema não adrenérgico não colinérgico

$\mathrm{NF}-\kappa \mathrm{B}$ - fator nuclear kappa B

NK - células natural killer

NO - óxido nítrico

$\mathrm{O}_{2}$ - oxigênio

OVx - Remoção dos ovários (ovariectomia)

$\mathrm{P}$ - progesterona

PBS - phosphate buffered saline

PEEP - pressão positiva no final da expiração

PR-A receptor A de progesterona 
PR-B - receptor B de progesterona

$\mathrm{RN}$ - resistência das vias aéreas

s.c. - via subcutânea

Sham - falsa operação (não OVx)

TNF- $\alpha$ fator de necrose tumoral alfa 


\section{SUMÁRIO}

1 INTRODUÇÃO

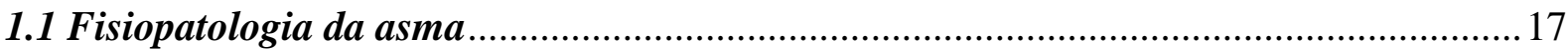

1.2 Hormônios sexuais femininos e inflamação pulmonar ...............................................2

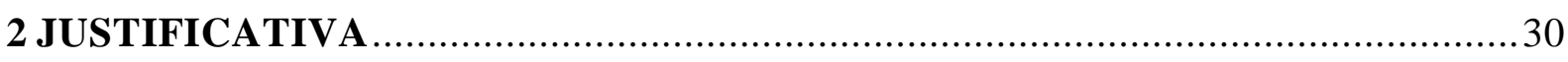

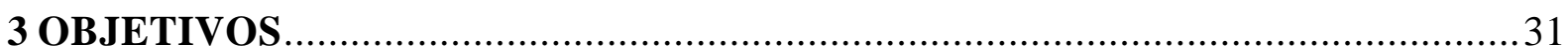

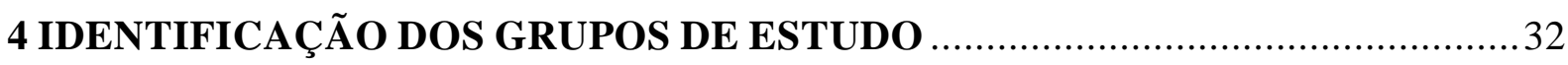

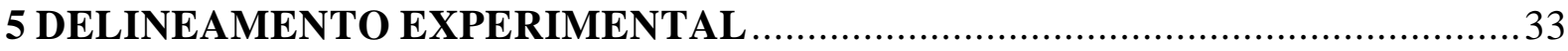

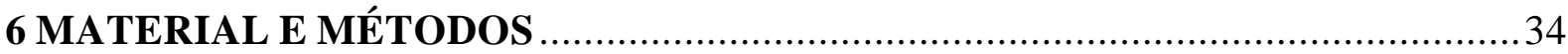

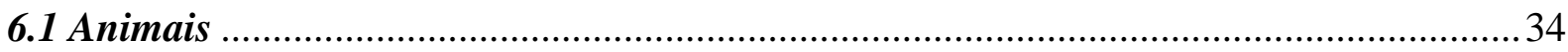

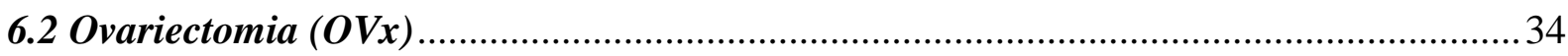

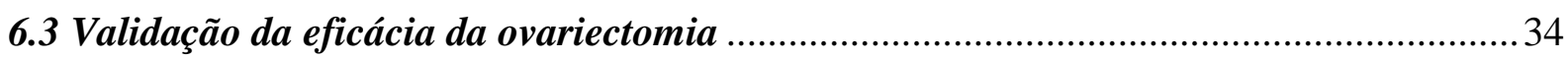

6.4 Análise do padrão morfológico das células presentes no lavado vaginal (LV).............. 34

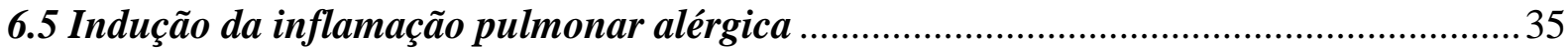

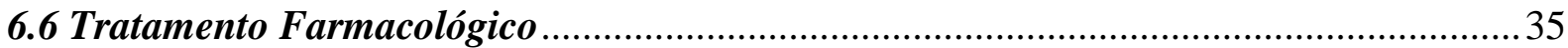

6.7 Quantificação de células presentes no Lavado Broncoalveolar (LBA) ..........................35

6.8 Determinação do número total de células na medula óssea ..............................................36

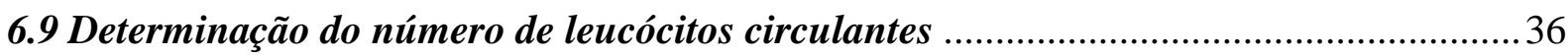

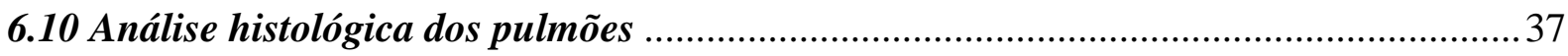

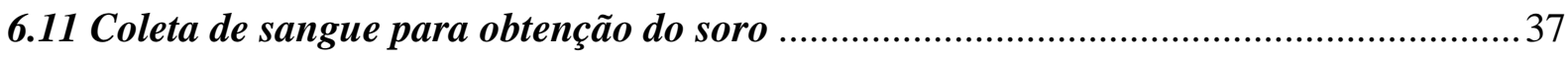

6.12 Determinação da concentração de estradiol e progesterona no soro ............................ 37

6.13 Quantificação da concentração de corticosterona no soro ........................................... 37

6.14 Avaliação da reatividade de segmentos isolados de traquéia in vitro ............................38

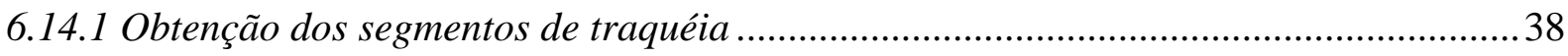

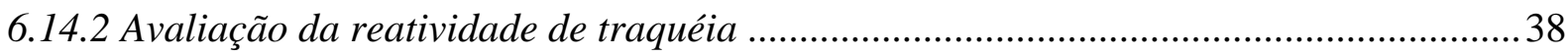

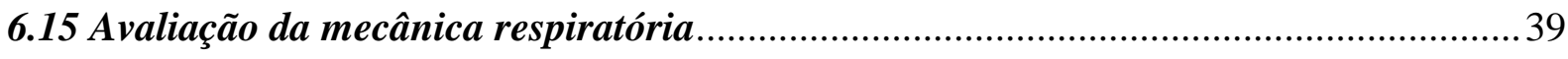

6.16 Cultura de fragmentos de pulmão isolado (explante) ................................................42

6.17 Quantificação de mediadores inflamatórios ...............................................................42

6.18 Quantificação de nitritos $\left(\mathrm{NO}_{2}\right)$ em amostras de explante pulmonar ..........................42

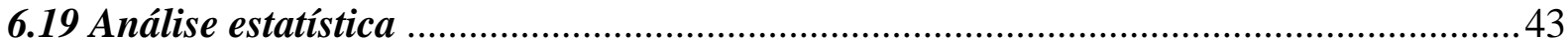

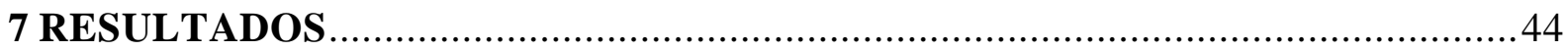

7.1 Efeito da remoção dos ovários sobre a massa uterina e ciclo estral..............................44 
7.2 Efeito da remoção dos ovários sobre a concentração circulante de estradiol e progesterona

7.3 Efeito do re-desafio com antígeno sobre o número de células presentes no lavado broncoalveolar (LBA) de animais alérgicos.

7.4 Efeito do re-desafio com antígeno em animais alérgicos sobre o número de leucócitos circulantes após broncoprovocação com ovoalbumina (OVA).

7.5 Efeito do re-desafio com antígeno em animais alérgicos sobre o número de células presentes no lavado de medula óssea (LM)

7.6 Efeito do re-desafio com antígeno em animais alérgicos sobre a produção de muco, colágeno e a migração celular - Análise histológica dos pulmões

7.7 Efeito do re-desafio com antígeno em animais alérgicos sobre a concentração plasmática de corticosterona

7.8 Efeito do re-desafio com antígeno em animais alérgicos sobre a reatividade traqueal in vitro.

7.9 Efeito do re-desafio com antígeno em animais alérgicos sobre a mecânica respiratória

7.10 Efeito do re-desafio com antígeno em animais alérgicos sobre a geração de mediadores inflamatórios em explante pulmonar.

7.11 Efeito do re-desafio com antígeno em animais alérgicos sobre a geração de $\mathrm{NO}_{2}$ em cultura de células explante pulmonar.

8 DISCUSSÃO 74

9 CONCLUSÕES. 


\section{INTRODUÇÃO}

\subsection{Fisiopatologia da asma}

A asma é uma doença inflamatória pulmonar crônica, caracterizada por episódios reversíveis de broncoconstrição, recrutamento de células inflamatórias para o pulmão, tais como macrófagos, neutrófilos e eosinófilos e pelo desenvolvimento de hiperreatividade das vias aéreas (GINA, 2014; HOLGATE, 2009; VAN DEN BERGE et al., 2009).

Recentes dados acerca da sua distribuição indicam que a asma é um problema de saúde pública com aproximadamente 300 milhões de indivíduos afetados em todo o mundo. De fato, a asma acomete pessoas de todas as idades, e quando não controlada pode deteriorar a qualidade de vida do paciente (ENFUMOSA, 2012; GINA, 2014; WORLD HEALTH ORGANIZATION, 2007).

No Brasil, a incidência da asma é bastante significativa (cerca de 18 milhões de pessoas), e é responsável por elevada parcela de absenteísmo ao trabalho (BIRNBAUN et al., 2002). Conforme os últimos dados do DATASUS, de janeiro a novembro de 2013, a asma foi a $2^{\text {a }}$ causa de internação hospitalar no "ranking" das internações relacionadas ao trato respiratório e $4^{\mathrm{a}}$ causa de internação hospitalar geral pelo SUS, levando a aproximadamente 122 mil internações e gerando um custo anual estimado em R $\$ 120$ milhões à rede pública de saúde (DATASUS, 2014).

Dentre os fatores que concorrem para o desencadeamento ou agravamento da asma destacam-se os fatores predisponentes (p.e. síntese exacerbada de IgE), causais (p. e. exposição ao pólen, ácaros, fungos, poluentes) e de contribuição, tais como a exposição à fumaça de cigarro, infecções virais e a oscilação dos níveis de hormônios sexuais femininos durante o ciclo sexual (GINA, 2014; PEREIRA-VEGA et al., 2012; WU; CHU, 2009).

Avaliando as características fisiopatológicas da asma é possível distinguir duas fases, que são designadas imediata e tardia. A fase imediata ocorre quando indivíduos sensibilizados são expostos ao alérgeno e desenvolvem desconforto respiratório que se inicia no período de 5 a 10 minutos (KUNG et al., 1990; SCHLEIMER et al., 1986). Neste período, observa-se desgranulação de mastócitos e ampla liberação de mediadores inflamatórios, cujos efeitos estão envolvidos com a broncoconstrição, o aumento da permeabilidade vascular e a secreção de muco (GINA, 2012). Como consequência dos mediadores inflamatórios liberados, advém, após algumas horas, a fase tardia, onde observamos aumento do recrutamento de linfócitos, neutrófilos e eosinófilos para o pulmão. Estes eventos pulmonares, quando recorrentes, 
contribuem para o desenvolvimento do quadro inflamatório pulmonar crônico, onde se verifica lesão epitelial brônquica com exposição das fibras sensoriais, hiperplasia das células de Goblet, aumento da secreção de muco e hiperreatividade das vias aéreas (CARRILLO DIAZ et al., 2006; MEHROTRA et al., 2009, SHUM et al., 2008). Em condições mais graves observam-se distúrbios dos mecanismos fisiológicos de reparo das vias aéreas que resultam no remodelamento, o qual pode se caracterizar pela deposição de colágeno, hipertrofia e hiperplasia das células musculares lisas de bronquíolos e brônquios e pelo aprisionamento de células inflamatórias (MURPHY; O'BRINE, 2010). Observam-se também alterações estruturais do citoesqueleto e das paredes bronquiolares (MEHROTRA et al., 2009). Em conjunto estas alterações podem comprometer a qualidade e a capacidade de contração e relaxamento das vias aéreas e consequentemente, sua atividade funcional (MURPHY; O'BYRNE, 2010; YING, 2006).

A agressão repetida ou intensa ao epitélio das vias aéreas causada pela contínua exposição ao antígeno associada à inflamação parece ser evento chave para o distúrbio dos mecanismos de reparo tecidual na asma. Nesse sentido, do ponto de vista de indução da asma, a sensibilização das vias aéreas como aquela observada na reação de hipersensibilidade imediata (tipo I) é passo inicial para o desenvolvimento da resposta imune associada à asma (BOCHER; BUSSE, 2005; GEISSMAN et al., 2010; KOBAYASHI et al., 2009).

O processo de sensibilização de um indivíduo tem início a partir do reconhecimento do antígeno pelas células apresentadoras de antígeno (APCs) tais como as células dendríticas (DCs) e macrófagos (VILLADANGOS; YOUNG, 2008). A dinâmica do processo de apresentação do antígeno inicialmente envolve sua fagocitose pela APC. Para tanto, as APCs migram para o linfonodo drenante, processam a estrutura do antígeno para peptídeos e o expõem para as células T (CHIEPPA et al., 2006; VILLADANGOS; YOUNG, 2008). Portanto, no contexto da indução da resposta imune adquirida, as células dendríticas ocupam lugar de destaque (AKIRA; TAKEDA, 2008; GEISSMANN, 2010; PALGAN et al., 2009; STEINMANN; COHN, 2007).

Os progenitores das DCs têm origem na medula óssea e seus precursores circulantes são denominados células dendríticas imaturas (BANCHEREAU et al., 2000). Estas células, quando estão localizadas em órgãos não linfóides (por exemplo, no pulmão), capturam e processam antígenos, todavia sem capacidade para apresentá-los às células $\mathrm{T}$ naive. Após a captação do antígeno as DCs imaturas sofrem alterações no seu padrão morfológico e funcional que resultam num estado de transição de uma célula captadora para uma célula apresentadora de antígeno (KELLER, 2001). É interessante notar que as DCs imaturas são 
potentes em fagocitar, mas apresentam baixos níveis de expressão de MHC de classe II e de moléculas co-estimuladoras (CD-40, CD-80, CD-86). Por outro lado, quando atingem seu estado maduro, as DCs alteram seu estado conformacional, aumentam a expressão de receptores para quimiocinas, superexpressam moléculas como o MHC de classe II, CD 40, CD 80 e CD 86 e tornam-se aptas a estimular células T naive (FRICK et al., 2010; REIS E SOUZA, 2006; WILSON et al., 2004).

A interação das células dendríticas com os linfócitos T naive é evento essencial na montagem da resposta imunológica. Antígenos uma vez processados podem implicar na liberação de citocinas pelas células dendríticas, as quais medeiam a diferenciação da célula $T$ naive para, no caso da asma, um perfil Th2 (AKIRA; UEMATSU; TAKEUCHI, 2006; RADHAKRISHNAN et al., 2007; WILLART; HAMMAD, 2010).

O direcionamento das respostas Th1/Th2 é um importante fator durante processo alérgico observado em pacientes asmáticos. Nesse contexto, linfócitos Th1 são capazes de gerar citocinas (como o IFN $\gamma$ ) contra patógenos intracelulares, que podem suprimir a função das células Th2. Contrariamente, citocinas derivadas de linfócitos Th2 como a IL-4 e a IL-13 são capazes de suprimir a resposta Th1 (KIM et al., 2013).

As citocinas são glicoproteínas que regulam processos como crescimento e a diferenciação celular, o processo inflamatório, a resposta imunológica e o reparo tecidual (NICOD, 1993; SCHUIJS et al., 2013). Na inflmação de origem alérgica, as citocinas IL-1 $\beta$, IL-4, IL-5, IL-10 e IL-13 ocupam lugar de destaque (SCHUIJS et al., 2013)

A IL-1 $\beta$ é uma citocina inflamatória implicada na ativação das células $\mathrm{T}$ e $\mathrm{B}$, na indução de outras citocinas regulatórias e induz a formação de moléculas de adesão endotelial, mecanismo essencial para migração celular nos tecidos inflamados (DINARELLO, 2011; QAMAR; RADER, 2012).

O TNF- $\alpha$ é liberado rapidamente após o estímulo inflamatório e tem importante papel na adesão de leucócitos a células endoteliais, no recrutamento celular e na indução de hiperreatividade das vias aéreas. É produzido principalmente por fagócitos mononucleares, células NK e células T (DINARELLO, 2011).

A liberação de mediadores como a IL-1 $\beta$ e o TNF- $\alpha$ durante o processo inflamatório provoca estímulos que são transmitidos ao sistema nervoso central e causam a liberação de Ach, a qual se liga a receptores nicotínicos presentes nas células inflamatórias e inibem a síntese de citocinas pró-inflamatórias. É a chamada via colinérgica anti-inflamatória (JONHSTON; WEBSTER, 2009; WANG et al., 2009). 
A IL-5 está relacionada à inflamação mediada por eosinófilos. Sabe-e que a IL-5 atua na diferenciação, recrutamento, ativação e sobrevida destas células (KOTSIMBOS, 1997; SCHUIJS et al., 2013).

A IL-13 também é sintetizada por diversos tipos celulares como células T, mastócitos entre outras, e está associada a produção de $\operatorname{IgE}$ e hiperreatividade das vias aéreas (HOLGATE, 2009).

Por fim, a IL-10 é produzida por monócitos, macrófagos, células NK, células dendríticas, eosinófilos, células $\mathrm{B}$, células $\mathrm{T}$ e apresenta potente função anti-inflamatória ao inibir a síntese de diversas citocinas e quimiocinas pró-inflamatórias (HEDRICH; BREAM, 2010).

Em condições alérgicas, quando citocinas inflamatórias como a IL-4, IL-5 e IL-13 são liberadas pelos linfócitos Th2, interagem com linfócitos B, promovem o "switching" e desencadeiam a síntese/liberação de imunoglobulina do tipo E (IgE) (O'BYRNE, 2013; para revisão ver GEHA, 2003). A IgE é reconhecidamente um anticorpo anafilático que se acopla a receptores FcERI presentes na membrana de mastócitos, tornando-os sensibilizados (BLANK et al., 2003; para revisão ver GEHA, 2003).

Uma vez sensibilizados, um segundo contato do organismo com o antígeno resulta na ativação dos mastócitos e consequente liberação de amplo espectro de mediadores inflamatórios tais como aminas vasoativas, mediadores lipídicos, citocinas, proteases, quimases, oxido nítrico, entre outros, cujos efeitos se associam ao aumento de permeabilidade vascular, broncoconstrição, secreção de muco, aumento da expressão de moléculas de adesão e recrutamento celular para o pulmão e hiperreatividade das vias aéreas. Tais eventos, em maior ou menor magnitude, são observados na fase inicial da resposta asmática e podem participar dos mecanismos envolvidos com o fenótipo da resposta inflamatória pulmonar crônica (LINDSTEST; KOVANEN, 2006; NIJKAMP; FOLKERTS, 1995; TAVARES DE LIMA et al., 1989).

No contexto da hiperreatividade das vias aéreas, vale lembrar que os eventos que contribuem para exacerbação da contração do músculo liso das vias aéreas são muitas vezes assistidos pela liberação de mediadores pró-inflamatórios (tais como histamina, leucotrienos, endotelina-1) ou neurotransmissores (como neuropeptídeos e, principalmente, ACh), (MEURS et al., 2008). O processo inflamatório pode induzir alterações importantes na micro estrutura do parênquima pulmonar, e modificar a mecânica ventilatória e o funcionamento do sistema respiratório como um todo (MEURS et al., 2008). 
O sistema nervoso autônomo parassimpático é um importante regulador da contratilidade das vias aéreas. No pulmão a inervação parassimpática se dá principalmente pelo nervo vago, e seu principal neurotransmissor é a acetilcolina (Ach). A acetilcolina se acopla a receptores muscarínicos, notadamente nos receptores do tipo M3 promovendo broncoconstrção, por isso, antagonistas muscarínicos são amplamente utilizados como broncodilatadores (GOSENS et al., 2008).

Em suma, o tônus colinérgico pode ser alterado pelo aumento da estimulação aferente por meio de mediadores inflamatórios, pelo aumento da liberação de acetilcolina pelas terminações nervosas colinérgicas e pela expressão alterada dos receptores muscarínicos e/ou redução dos neurotransmissores inibitórios (KANAZAWA, 2006).

Além do parassimpático, a contração do músculo liso das vias aéreas também pode ser modulada pelo sistema NANC (sistema não adrenérgico não colinérgico). As ações excitatórias (eNANC) são efetuadas por meio de neurotransmissores como a substância p (SP) e a Neurocinina A (NKA), e ações inibitórias (iNANC) são mediadas por neurotransmissores como óxido nítrico e o peptídeo intestinal vasoativo (VIP) (ALMEIDA et al., 2004; PRADO et al., 2005).

No que diz respeito à contração muscular das vias aéreas mediada pelo sistema nãoadrenérgico não-colinérgico (NANC), o papel do óxido nítrico (NO) como neurotransmissor endógeno e potente mediador da resposta inflamatória ocupa lugar de destaque (FISCHER et al., 2002; JOOS et al., 2000; RICHARDSON et al., 1976).

Nas vias aéreas, o óxido nítrico está relacionado a eventos ligados à manutenção do tônus vascular, do tônus brônquico, e exsudação plasmática, dentre outras funções fisiológicas, como neurotransmissão, regulação da pressão sanguínea, prevenção da agregação plaquetária, inibição da adesão de leucócitos ao endotélio, efeito antioxidante e defesa do organismo (BARNES, 1995; BISHOP; ANDERSON, 2005).

O óxido nítrico é um gás altamente difusível, sintetizado a partir do aminoácido LArginina, substrato também utilizado na via da arginase. As vias da arginase e do óxido nítrico podem, portanto, interferir uma com a outra em competição pelo substrato. Durante a asma, o aumento de citocinas inflamatórias resulta na amplificação da via arginasedependente e em conseqüência, a supressão de óxido nítrico endógeno. Isso conduz a hiperreatividade brônquica, aumento da secreção de muco e, conforme o aumento da freqüência de exposição ao antígeno, piora da função pulmonar (BARNES, 1995; NIJCAMP; FOLKERTS, 1995; STARLING et al., 2009). 
Alguns modelos matemáticos relacionam valores de fluxo e pressão e oferecem parâmetros para o estudo da função pulmonar; para tanto, diversos ventiladores mecânicos foram criados e, em conjunto, fornecem os dados que nos permitem estudar a função pulmonar.

O flexiVent (SCIREQ®, Montreal, Quebec, Canadá) é um ventilador mecânico utilizado na prática experimental para medir parâmetros de resistência das vias aéreas e elastância pulmonar in vivo, em pequenos animais. De modo simplificado, o flexiVent injeta no pulmão do animal, por meio de uma cânula endotraqueal, um volume de gás (ar atmosférico) conhecido, onde o fluxo desse gás é obtido, matematicamente, pela derivada do volume. A pressão gerada por esse volume é adquirida na entrada das vias aéreas do animal. Logo, com estes três parâmetros conhecidos, os valores de resistência e elastância do sistema respiratório podem ser calculados pelo equipamento.

O estudo dos mecanismos que regulam a inflamação pulmonar, notadamente das ações do óxido nítrico, da reatividade in vitro e da mecânica pulmonar permitem uma compreensão adicional da engrenagem envolvida na regulação da inflamação alérgica pulmonar e pode contribuir para novas descobertas de intervenções terapêuticas que possam melhorar a qualidade de vida de asmáticos.

\subsection{Hormônios sexuais femininos e inflamação pulmonar}

Dentre os fatores que concorrem para o agravamento dos sintomas da asma, a oscilação dos hormônios sexuais femininos durante o ciclo sexual ocupa lugar de destaque (PEREIRA-VEGA et al., 2012; VAN DEN BERGE et al., 2009). Existem estudos evidenciando que, em crianças, os episódios de crise asmática são mais prevalentes em meninos quando comparados ao observado em meninas. Por outro lado, este quadro se inverte após a puberdade, quando se observa piora da asma em mulheres quando comparada a homens (ANTUNES et al., 2010; CHEN, 2008; HODYL et al., 2010).

Estudo realizado por Chandler et al. (1997), estimou que 33 a 52\% das mulheres asmáticas desencadeiam piora dos seus sintomas no período pré-menstrual. Ainda, $22 \%$ das mulheres asmáticas apresentam piora dos sintomas durante a menstruação (CHANDLER et al., 1997, MURPHY; GIBSON 2008). Mais recentemente, Pereira-Vega et al (2010), mostraram que mulheres adultas e de qualquer raça apresentam maior morbidade e mortalidade por asma quando comparadas a homens, e respondem por $75 \%$ das internações hospitalares e $65 \%$ das visitas a serviços de emergência. 
Embora a relação entre a concentração dos hormônios sexuais femininos e piora da asma no período pré-menstrual seja amplamente discutida na literatura, há poucos trabalhos que fazem relatam a incidência ou piora dos sintomas da asma em mulheres após a menopausa.

Uma pesquisa realizada por Real et al. (2008), analisou a função pulmonar de aproximadamente mil mulheres, que também responderam a um questionário sobre a saúde respiratória. Os cientistas mediram ainda a concentração dos hormônios sexuais nas mulheres que tinham entre 45 e 56 anos. Os resultados apontaram que as mulheres na pós-menopausa apresentaram piora da função pulmonar e outros sintomas de problemas respiratórios.

Nesse mesmo sentido, Jensen-Jarolim e Untersmayr (2008), sugeriram que mulheres na pós-menopausa teriam aumento na incidência de episódios de asma e que estes episódios poderiam ser amplificados na vigência de terapia de reposição hormonal.

A terapia de reposição hormonal vem sendo utilizada por milhões de mulheres em todo o mundo com o intuito de melhorar os sintomas da menopausa e realmente têm-se provado benefícios com relação à função sexual, à saúde do trato urinário, osteoporose, dentre outros (SCHIMIDT, 2012); mas relativamente pouca atenção tem sido dada ao impacto da terapia de reposição hormonal sobre doenças respiratórias, com exceção do câncer de pulmão (OH et al., 2010; TICCONI et al., 2013).

A percepção do envolvimento dos hormônios sexuais femininos na asma também é referida pelos pesquisadores do Instituto Nacional de Saúde Pública do México e do Instituto Gustave Roussy, da França, em um estudo realizado com 58 mil mulheres durante 12 anos. Neste estudo observou-se que mulheres na pós-menopausa, sob terapia de reposição hormonal, apresentaram maior risco para o desenvolvimento de asma, sendo o risco ainda maior (54\%) entre as mulheres sob terapia com apenas estrógeno (oglobo.globo.com, 2010).

Historicamente, os primeiros relatos acerca do papel dos hormônios sexuais femininos na asma foram apresentados por Frank, em 1931. Este autor introduziu o conceito de asma pré-menstrual ao reconhecer que a piora dos sintomas da asma poderia decorrer da variação dos níveis dos hormônios circulantes observada durante o ciclo sexual feminino. Frank observou também maior incidência de dores de cabeça, irritabilidade, agressividade e aumento na variabilidade do pico de fluxo expiratório (PFE) no período de 2 a 3 dias que antecedem a menstruação e identificou que a piora dos sintomas se correlacionou com a redução dos níveis circulantes de hormônios sexuais e na urina durante o período prémenstrual. 
A partir dos achados de Frank em 1931, estudos adicionais documentaram o agravamento dos sintomas da asma e da função pulmonar durante os períodos pré e intramenstrual em mulheres asmáticas (MURPHY; GIBSON, 2008; ROSSOLINI; CHIEFFI, 1964; STANFORD et al., 2006; TAKEDA et al., 2013; TURNER et al., 1981; UKENA et al., 1990). A despeito do mencionado, os mecanismos envolvidos com a piora da asma em decorrência das variações dos hormônios sexuais femininos durante as fases do ciclo sexual não estão totalmente elucidados (HODYL, et al., 2010; OKUYAMA et al., 2008; TAKEDA et al., 2013; VAN DEN BERGE, 2009).

Resumidamente, o ciclo sexual humano dura cerca de vinte e oito dias e é dividido em 2 fases: a fase folicular, caracterizada pelo aumento crescente da concentração de estradiol e a fase lútea, caracterizada pelo declínio da concentração de estradiol e aumento da síntese e liberação de progesterona. No período tardio da fase lútea, em que os níveis de progesterona também começam a diminuir, ocorre a menstruação, fechando o ciclo (HANLEY, 1981).

Em camundongos, o ciclo reprodutivo tem duração 4 a 5 dias e é bem descrito na literatura (GOLDMAN et al., 2007). Caracteriza-se por 4 fases bem típicas: proestro, estro, metaestro (diestro I) e diestro (diestro II) (FREEMAN, 1988; LONG; EVANS, 1992), sendo que a ovulação inicia-se no proestro e termina no estro (GOLDMAN et al., 2007; LONG; EVANS, 1992; SCHWARTZ, 1964; YOUNG et al., 1941).

Nosso laboratório investiga a participação dos hormônios sexuais femininos na modulação da inflamação pulmonar de origem alérgica (ACCETTURI, 2009; GIMENESJÚNIOR, 2013; LIGEIRO DE OLIVEIRA et al., 2004; LINO-DOS-SANTOS-FRANCO et al., 2013; MARTINS, 2013; RIFFO-VASQUEZ et al., 2007) e não alérgica (BREITHAUPTFALOPPA; FANTOZZI.; VITORETTI, 2014). No que tange a inflamação alérgica, os estudos começaram a ser conduzidos em ratas a partir de 2000, e mais recentemente em camundongos (ACCETTURI, 2009; DE OLIVEIRA et al., 2010; LIGEIRO DE OLIVEIRA et al., 2004; LIGEIRO DE OLIVEIRA, 2000; OLIVEIRA et al., 2013; RIFFO-VASQUEZ et al., 2007; ROCHA DA LAPA et al., 2013; RODRIGUES-SOARES, 2010). Para tanto, usamos o modelo de imunização dos animais com o antígeno (ovoalbumina) em distintos períodos após a remoção cirúrgica dos ovários. Nossos dados mostram que existe relação entre a concentração circulante dos hormônios sexuais femininos e o momento em que ocorre a sensibilização dos animais ao antígeno. Assim, a sensibilização de animais 1 dia após a remoção dos ovários, onde a concentração dos hormônios sexuais femininos circulante está dentro dos padrões normais, acarreta no aumento da inflamação alérgica pulmonar (LIGEIRO DE OLIVEIRA et al., 2007). Por outro lado, quando a sensibilização ao antígeno ocorre 7 
dias após a remoção dos ovários, condição onde a concentração circulante de hormônios sexuais femininos está abaixo de valores normais, não há desenvolvimento da inflamação pulmonar alérgica (DE OLIVEIRA et al., 2007; LIGEIRO DE OLIVEIRA et al., 2004). Além disso, nossos estudos também mostraram que camundongos fêmeas quando imunizados na presença de reduzidos níveis circulantes de hormônios sexuais femininos (causados pela ovariectomia), tiveram redução da resistência pulmonar (RIFFO-VASQUEZ et al., 2007). As observações acerca do envolvimento dos hormônios sexuais femininos no momento da sensibilização dos animais poderiam sugerir importante influência sobre as células dendríticas e moléculas co-estimuladoras durante o processo de sensibilização ao antígeno. Nesse sentido, estudos do nosso grupo (ACCETTURI, 2009) indicaram aumento de CD80, CD86, CD40 e MHC de classe II nas células dendríticas de animais não alérgicos com 7 dias de ovariectomia. Ainda, tais parâmetros não alteraram quando os animais ovariectomizados foram sensibilizados e desafiados com o antígeno. Vale lembrar que nestas condições os animais OVx alérgicos não desenvolveram inflamação alérgica pulmonar (ACCETTURI, 2009). Por outro lado, animais falsamente operados, portanto com os ovários intactos, não apresentaram alteração na expressão de moléculas co-estimuladoras após 7 dias da falsa manipulação cirúrgica, todavia desenvolveram significativo aumento da expressão de moléculas co-estimuladoras após o desafio antigênico, fato que foi acompanhado pelo desenvolvimento de inflamação alérgica pulmonar. Visto a participação das moléculas coestimuladoras para o processamento de antígenos e desencadeamento da resposta imune, então é possível que outros parâmetros da resposta alérgica pulmonar possam ser mediados pelas mesmas, e que estejam sob influência dos hormônios sexuais femininos.

A análise geral dos dados obtidos em relação à interação dos hormônios sexuais femininos com as moléculas co-estimuladors presentes na superfície das células dendríticas permitiu sugerir que a população e o processo de maturação de células dendríticas podem ser mediados pelos hormônios sexuais femininos. Ainda, os mecanismos envolvendo o aumento da expressão de moléculas co-estimuladoras no baço (CD80, CD86, CD40 e MHC de classe II), linfonodo (CD80, CD86, CD40 e MHC de classe II) e no lavado broncoalveolar (CD80, CD86, CD40 e MHC de classe II) após o desafio antigênico dos animais aparentemente não medeiam o recrutamento de células para o pulmão durante o processo inflamatório. Vale lembrar que estes estudos foram conduzidos em animais ovariectomizados que posteriormente foram imunizados e desafiados. Portanto, o aumento da expressão de moléculas coestimuladoras causado pela $\mathrm{OVx}$ anterior ao estímulo sensibilizante não deve se associar ao 
desenvolvimento da IAP. Neste contexto, é possível que os hormônios sexuais femininos medeiem o curso da doença inflamatória já instalada.

É importante salientar que em cultura de células dendríticas provenientes de camundongos fêmeas naive, a progesterona exerce efeito anti-inflamatório, enquanto o estrógeno revela ter efeito pró-inflamatório, sugerindo um controle hormonal da atividade funcional dessas células (JENSEN-JAROLIM; UNTERSMAYR, 2008). De fato, estudos realizados em nosso laboratório mostraram que a progesterona atenua, enquanto o estradiol exacerba a desgranualação de mastócitos obtidos de ratas alérgicas ovariectomizadas (DE OLIVEIRA et al., 2007).

Em modelo onde os animais foram primeiramente ovariectomizados (ou falsamente ovariectomizados) e sensibilizados após 7 dias do ato cirúrgico, nossos dados revelaram aumento de citocinas anti-inflamatórias (IL-10) no explante pulmonar dos animais ovariectomizados e aumento da geração de citocinas pró-inflamatórias (IL-1, IL-4, IL-13 e TNF- $\alpha$ ) no explante pulmonar de camundongos fêmeas com os ovários intactos, (ACCETTURI, 2009).

Sabe-se que estas citocinas estão implicadas com o desenvolvimento da inflamação alérgica pulmonar, remodelamento das vias aéreas, e nas alterações funcionais observadas no pulmão de asmáticos. Ainda, estas citocinas favorecem a produção de anticorpos, particularmente a IgE, contribuem para a proliferação de eosinófilos e para a ativação e migração de mastócitos (MOSMANN et al., 1996; VENKAYYA et al., 2002; WANG et al., 2010; WALTER et al., 2001).

É bem estabelecido que o estrógeno e a progesterona exercem seus papeis regulatórios ligando-se a receptores específicos, conhecidos como receptores de estrógeno alfa e beta (ER$\alpha$ e ER- $\beta$ ) e receptores de progesterona (PR-A e PR-B) (ELLMAN, 2009; HEWITT et al., 2005).

Além do trato reprodutivo, os receptores de estrógeno e de progesterona são encontrados expressos em outros tecidos como mamas, ossos, coração, cérebro, pulmão (COUSE et al., 1997; KEOHLER et al., 2005). Esta observação torna-se relevante em virtude do mecanismo de ação de alguns moduladores seletivos de receptores de estrógeno como o tamoxifeno, os quais podem atuar como antagonistas nos pulmões e agonistas em outros tecidos, como por exemplo, nos ossos (BROSENS, 2004; SMITH, 1993).

Sabe-se que os dois subtipos de receptores de estrógeno (ER- $\alpha$ e ER- $\beta$ ) são expressos nos pulmões, embora a expressão e o papel específico de cada um deles pareça ser diferente. O receptor de estrógeno $\alpha$ parece regular a formação dos alvéolos em número e tamanho 
(MASSARO; MASSARO, 2006), enquanto o receptor $\beta$, que é encontrado em maior densidade nos brônquios, controla a composição da matriz extracelular que, por sua vez, é responsável pela elasticidade alveolar (IVANOVA et al., 2009).

A literatura ainda é carente quando se trata dos receptores de progesterona. Sabe-se que tanto o PR-A quanto PR-B possuem as mesmas afinidades pela progesterona, embora o PR-A tenha revelado efeito inibidor e o PR-B efeito ativador junto ao DNA (BROSENS, 2004; NISWENDER et al., 2002).

No que diz respeito aos receptores de estrógeno, até pouco tempo apenas receptores nucleares haviam sido descritos, entretanto, receptores de estrógeno acoplados a proteína $G$ também foram identificados (JALA et al., 2012; LEVIN, 2011). Acredita-se que da ligação do estrógeno a estes receptores de membrana advém a resposta celular não genômica, modulando um dos mecanismos mais importantes para contração do músculo liso, que é o influxo de $\mathrm{Ca}^{2+}$ (LEVIN, 2011).

Resumidamente, em condições asmáticas, a acetilcolina liberada pelas terminações nervosas colinérgicas liga-se ao receptor de membrana da célula muscular lisa, criando um potencial pós-sináptico excitatório na fibra muscular. A geração de potenciais de ação tem como evento final a liberação de $\mathrm{Ca}^{+}$no meio intracelular. $\mathrm{O} \mathrm{Ca} 2^{+}$se liga com a troponina e desencadeia uma alteração na conformação do complexo troponina/tropomiosina, levando à ativação do ATP e ao acoplamento físico-química entre actina e miosina. Ocorre então o deslizamento dos filamentos finos (actina) sobre os filamentos grossos (miosina) culminando na contração da célula muscular lisa (MURRAY et al., 2013). Durante processo de relaxamento, entretanto, há o aumento de AMP cíclico (cAMP) que estimula a PKA ("quinase da proteína A”), estimula a PKG (“quinase da proteína G”) e diminui o $\mathrm{Ca}^{+}$intracelular, levando ao relaxamento (KANAZAWA, 2006).

De acordo com Towsend et al. 2012, ao se ligar em seu receptor de membrana, o estrógeno pode interferir com a via do AMPc, reduzir de forma não genômica o influxo de $\mathrm{Ca}^{+}$e promover broncodilatação.

Em suma, a literatura aponta que o estrógeno pode alterar, por meio de receptores nucleares e/ou via receptores de membrana, diversas etapas do curso da inflamação alérgica pulmonar como, a migração celular, a geração de mediadores e também a reatividade das vias aéreas (CARDOSO et al., 2010).

Estudos da década de 1980 e 1990 revelaram que o estradiol inibe a apresentação de antígenos por células epiteliais e macrófagos, enquanto a progesterona exerce efeito contrário. Ainda, observou-se que o estradiol também exerce efeito pró-inflamatório em condições 
alérgicas (DE OLIVEIRA et al., 2007; KAGNOFF, 1996; MATSUBARA et al., 2008; WIRA et al., 2000). Wira et al. (2000), mostraram em cultura celular que o estradiol diminui a apresentação de antígenos pelas células dendríticas, enquanto a progesterona induz maturação e diferenciação dessas células. Nalbadian et al. (2005), indicaram que o tratamento de camundongos fêmeas com moduladores seletivos de receptores de estrógeno (raloxifeno e tamoxifeno) implica na maturação e ativação de células dendríticas. Em contraste, Bengtsson et al (2004), revelaram que o estradiol estimula as células dendríticas de maneira a causar liberação de citocinas pró-inflamatórias como IL-1 e IL-4. Rettew et al. (2009), demonstraram que o bloqueio da ligação do estrógeno a seu receptor diminui a produção das citocinas próinflamatórias. Além disso, Douin-Echinard et al. (2008), mostraram que animais deficientes de receptores de estrógeno do tipo $\alpha$ apresentam reduzida expressão de MHC de classe II e da molécula co-estimuladora CD86. Estes dados reforçam o potencial papel destes esteróides na modulação da função das células dendríticas e na produção de mediadores. Neste sentido, fortalece-se o conceito de que os hormônios sexuais femininos influenciam a resposta funcional da célula $\mathrm{T}$ e consequentemente a resposta inflamatória (HAMMAD; LAMBRECHT, 2008; VÉLEZ-ORTEGA et al., 2013).

É interessante notar que realmente, o envolvimento dos hormônios sexuais femininos na atividade do sistema imune é fortalecido pelos achados de Fish (2008). Esta autora mostra que a variação dos níveis de estrógeno e progesterona durante as diferentes fases do ciclo menstrual interfere com o padrão das populações de linfócitos T. Segundo a autora, durante a fase folicular do ciclo sexual, quando o nível circulante de estrógeno está elevado, observa-se aumento do número de células T reguladoras e predomínio de resposta Th2. Em contrapartida, durante a fase lútea, quando os níveis de estrógeno estão baixos, verifica-se predomínio da resposta Th1 (figura 1). 


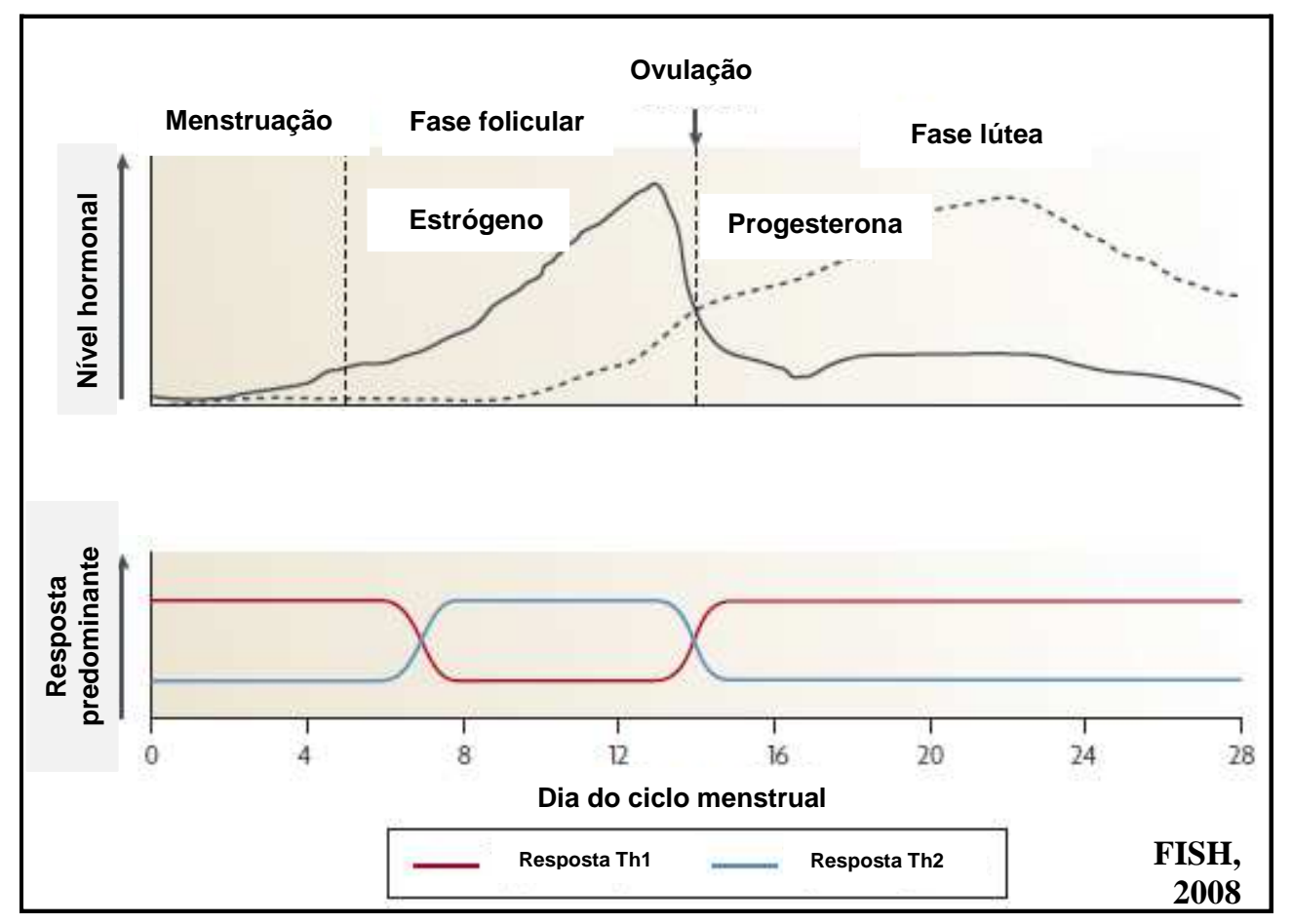

Figura 1- Envolvimento dos hormônios sexuais femininos na atividade do sistema imune

Embora os dados apresentados na literatura sobre a modulação dos hormônios sexuais femininos no desenvolvimento da inflamação pulmonar ainda sejam conflitantes, ora mostrando indução e ora mostrando atenuação da inflamação, é perceptível a participação modulatória do estrógeno e da progesterona no desenvolvimento da resposta inflamatória pulmonar. À luz destas evidências e considerando que a piora da função pulmonar é consequência da asma, no presente estudo investigamos as repercussões da re-exposição ao antígeno após a remoção dos ovários de animais com a asma experimental já desencadeada. $\mathrm{O}$ estudo poderá fornecer subsídios para a compreensão dos mecanismos que medeiam a piora da inflamação alérgica pulmonar em mulheres na fase pré-menstrual ou na pós-menopausa, bem como permitirão, no futuro, propor alternativas terapêuticas para esta importante doença. 


\section{JUSTIFICATIVA}

Mulheres asmáticas relatam piora dos sintomas durante o período pré-menstrual e na pós-menopausa. Similarmente, a piora da asma também é observada em mulheres na pósmenopausa que estão sob terapia de reposição hormonal. Neste cenário, existe a percepção de que a variação dos níveis circulantes dos hormônios sexuais femininos durante o ciclo menstrual e sua redução no período da pós-menopausa exerce importante papel modulador na asma. Os mecanismos pelos quais os hormônios sexuais femininos interferem no desencadeamento da asma ainda são contraditórios, ora mostrando papel indutor e ora mostrando papel atenuador na inflamação pulmonar e ainda não totalmente elucidados. À luz dos nossos dados acerca da expressão de moléculas co-estimuladoras e a magnitude da inflamação pulmonar em animais alérgicos previamente submetidos à remoção dos ovários e considerando o potencial papel modulador dos hormônios sexuais femininos em mulheres asmáticas, o presente estudo apresenta um enfoque adicional à investigação, na medida em que avaliará o papel da oscilação dos níveis dos HSF não mais sobre a sensibilização dos animais, mas sim numa condição alérgica previamente instalada. A hipótese é que este modelo permitirá investigar o papel dos hormônios sexuais numa condição que potencialmente mimetize àquela encontrada em mulheres asmáticas durante o ciclo menstrual ou mesmo na pós-menopausa. 


\section{OBJETIVOS}

Avaliar o efeito da re-exposição ao antígeno após a remoção dos ovários de camundongos fêmeas previamente alérgicas e suas repercussões pulmonares e sistêmicas. Ainda, verificar o efeito da re-exposição ao antígeno após o tratamento com estrógeno e progesterona sob os mesmos parâmetros. 


\begin{tabular}{c|l}
\hline Basal & \multicolumn{1}{c}{ Animais não manipulados } \\
\hline Alérgico OVx & $\begin{array}{l}\text { Imunizados, desafiados, submetidos a remo- } \\
\text { ção dos ovários e re-desafiados. }\end{array}$ \\
\hline Alérgico Sham/OVx & $\begin{array}{l}\text { Imunizados, desafiados, falsamente-operados } \\
\text { e re-desafiados }\end{array}$ \\
\hline Alérgico OVx + estrógeno & $\begin{array}{l}\text { Imunizados, desafiados, submetidos a remo- } \\
\text { ção dos ovários, tratados com estrógeno e re- } \\
\text { desafiados }\end{array}$ \\
\hline Alérgico OVx + progesterona & $\begin{array}{l}\text { Imunizados, desafiados, submetidos a remo- } \\
\text { ção dos ovários, tratados com progesterona e } \\
\text { re-desafiados }\end{array}$ \\
\hline Alérgico OVx + progesterona + estrógeno & $\begin{array}{l}\text { Imunizados, desafiados, submetidos a remo- } \\
\text { ção dos ovários, tratados com progesterona e } \\
\text { com estrógeno e re-desafiados }\end{array}$ \\
\hline
\end{tabular}




\section{Grupos}

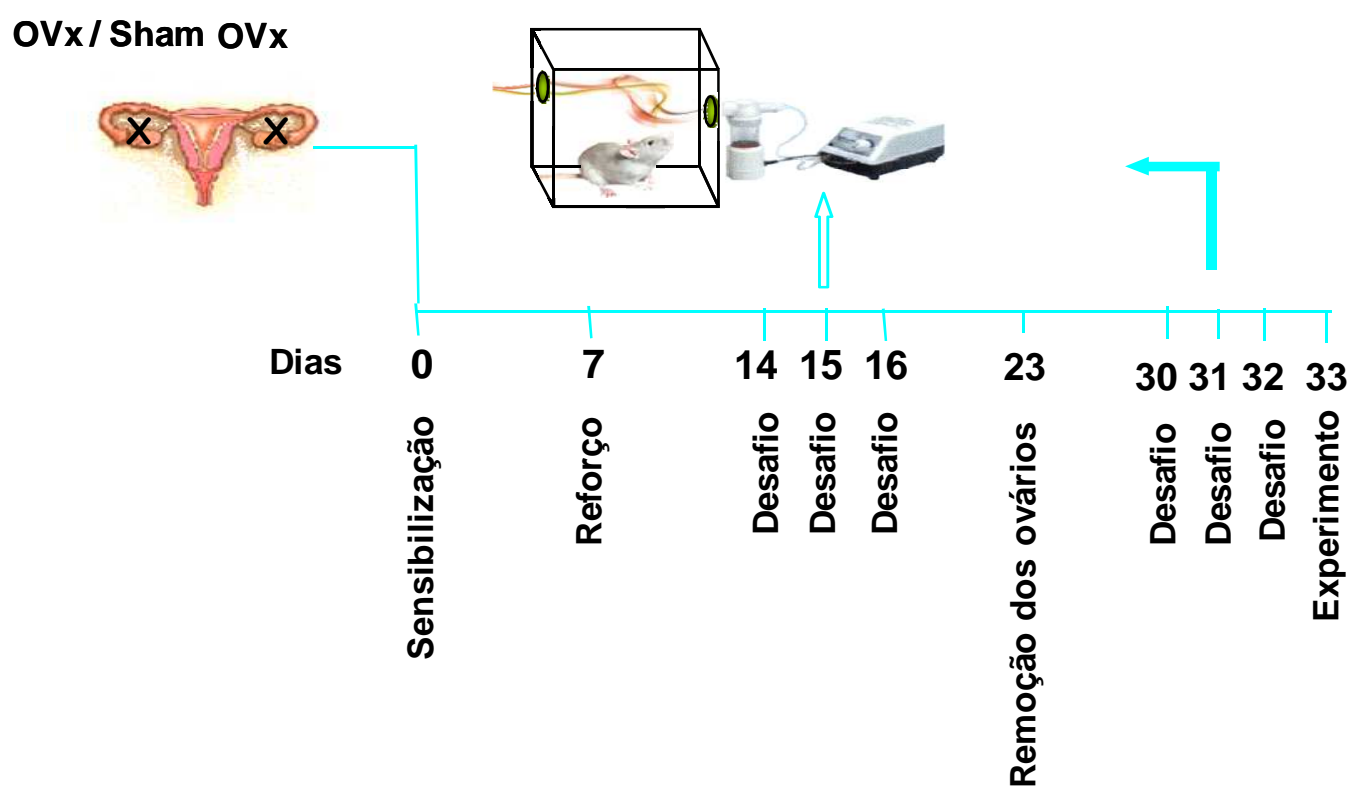

Grupos OVx tratados com estrógeno ou progesterona

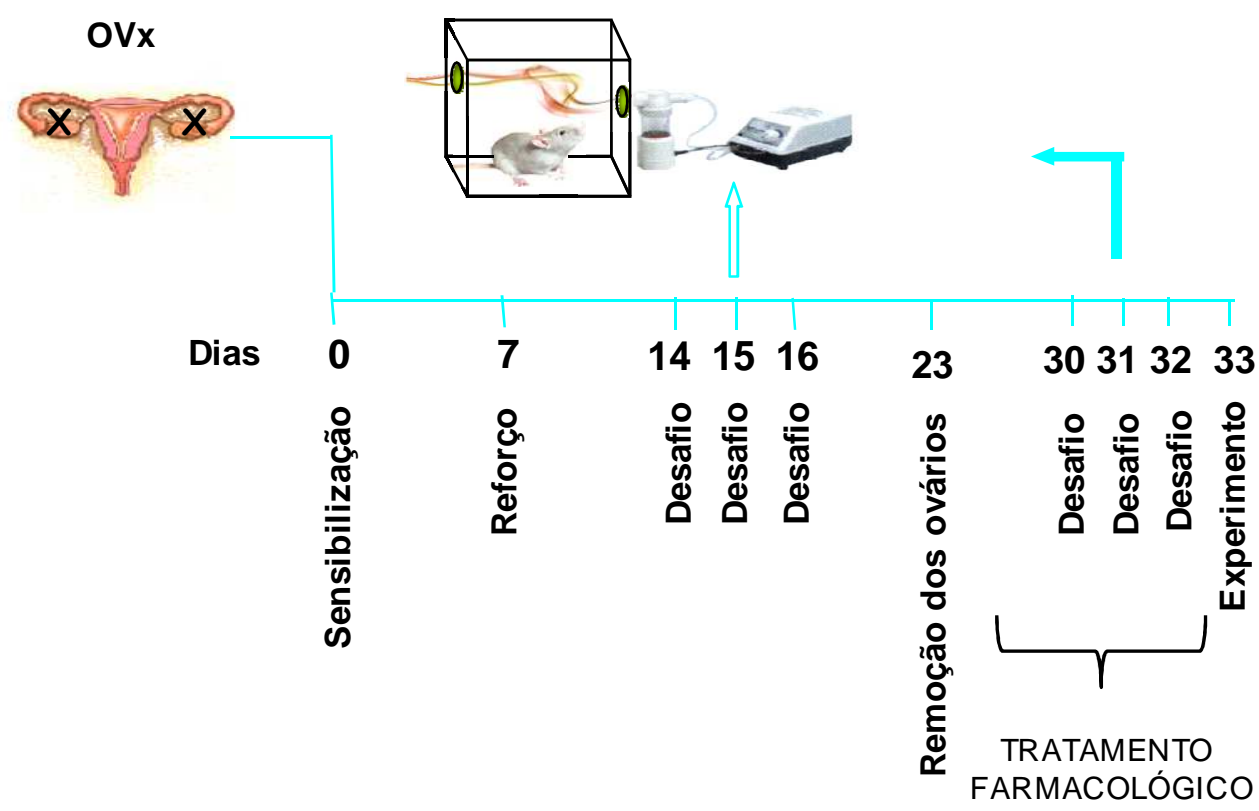

Delineamento experimental proposto para o estudo. Os grupos consistiram de animais não manipulados (basal), animais sensibilizados, desafiados com OVA posteriormente ovariectomizados e novamente desafiados com OVA (alérgico OVx), animais sensibilizados, desafiados com OVA posteriormente ovariectomizados, tratados com estrógeno ou progesterona e novamente desafiados com OVA (grupos estrógeno e progesterona) e como controle foram utilizadas camundongos fêmeas sensibilizadas e desafiadas com OVA e posteriormente submetidos à falsa cirurgia de remoção dos ovários e novamente desafiadas com OVA (alérgico Sham-OVx). 


\subsection{Animais}

Foram utilizados camundongos fêmeas da linhagem Balb/c, adultos, com idade entre 45-60 dias e peso entre 18-22 g, provenientes do Biotério do Departamento de Farmacologia do Instituto de Ciências Biomédicas da Universidade de São Paulo (ICB-USP). Os animais foram mantidos em condições de temperatura e umidade controladas e ciclo claro-escuro de 12 horas, com livre acesso a água e ração. Os experimentos foram realizados com a aprovação da Comissão de Ética no Uso de Animais do ICB-USP.

\subsection{Ovariectomia $(\mathrm{OVx})$}

Os animais foram anestesiados por via inalatória com isoflurano a $1,5 \%$ por litro de $\mathrm{O}_{2}$. A seguir, após tricotomia e assepsia da parede abdominal com álcool iodado a $3 \%$ foi realizada laparotomia mediana. Após a identificação dos ovários foi feita a ligadura de seus pedúnculos e em seguida a ressecção dos tecidos ovarianos. A parede abdominal foi fechada em dois planos utilizando sutura contínua de fio de nylon 4.0. Como controle, fêmeas igualmente manipuladas foram utilizadas, sem, entretanto, haver a ressecção do tecido ovariano (grupo alérgico Sham/OVx). Após a cirurgia foi administrado tramadol $(5 \mathrm{mg} / \mathrm{kg}$, i.m.) para a analgesia e pentabiótico $(540 \mathrm{mg} / \mathrm{kg}$, i.m.).

\subsection{Validação da eficácia da ovariectomia}

Após 24 horas do último re-desafio, os animais foram submetidos à eutanásia com dose excessiva de anestésicos (xilazina e cetamina > $20 \mathrm{mg} / \mathrm{Kg}$ e $100 \mathrm{mg} / \mathrm{kg}$ respectivamente) para remoção do útero e determinação do seu peso. $O$ sucesso da ovariectomia foi avaliado pela detecção da redução no peso do útero, pela redução dos níveis circulantes de estrógeno e progesterona e pela análise do padrão morfológico das células presentes no lavado vaginal (LV).

\subsection{Análise do padrão morfológico das células presentes no lavado vaginal (LV).}

Com o auxílio de um conta-gotas, uma alíquota de solução salina tamponada com fosfato (PBS) foi introduzida na vagina e o LV retirado. Amostras do LV foram colocadas 
sobre lâmina de vidro e a seguir diluídas em $5 \mu$ l de corante cristal violeta (5\%), e então observadas por microscopia de luz. Somente fêmeas ovariectomizadas em diestro e com redução da massa uterina foram incluídas no estudo. Como controle foram utilizados animais com ovários intactos independente da fase do ciclo estral.

\subsection{Indução da inflamação pulmonar alérgica}

Os animais foram sensibilizados pela injeção (via subcutânea) de ovoalbumina (OVA Grau V, sigma, $10 \mu \mathrm{g}, 0,2 \mathrm{ml}$ ) adsorvida em hidróxido de alumínio. Após 7 dias da sensibilização os animais receberam reforço com a mesma solução, também por via subcutânea. Sete dias após o reforço, os animais foram expostos 1 vez ao dia, durante 3 dias consecutivos à inalação de OVA por 15 minutos. Para tanto, cinco animais foram colocados, por sessão, em caixa plástica $(18,5 \mathrm{~cm}$ X 18,5 $\mathrm{cm}$ X 13,5 cm) acoplada a um nebulizador ultrassônico (ICEL, São Paulo, São Paulo, Brasil) com capacidade de produzir névoa com partículas entre 0,5 a $1,0 \mu \mathrm{m}^{3}$. Sete dias após o último desafio os animais foram ovariectomizados ou não. Decorridos mais sete dias do ato cirúrgico, os animais foram novamente expostos 1 vez ao dia, durante 3 dias consecutivos à inalação de OVA por 15 minutos (re-desafiados).

\subsection{Tratamento Farmacológico}

Os animais alérgicos OVx foram tratados com $17 \beta$-estradiol solúvel em água $(13 \mu \mathrm{g} / \mathrm{kg}$, s.c.) ou progesterona (14 $\mu \mathrm{g} / \mathrm{kg}$, s.c.). O estradiol e a progesterona foram administrados $4 \mathrm{~h}$ antes de cada re-desafio.

\subsection{Quantificação de células presentes no Lavado Broncoalveolar (LBA)}

O LBA foi realizado baseado na metodologia utilizada por De Lima et al (1992). Nesta etapa de experimentos, os animais foram anestesiados com dose excessiva de cetamina e xilazina ( $<100$ e $20 \mathrm{mg} / \mathrm{kg}$, i.p.), a cavidade peritoneal exposta e foi realizada a eutanásia por dessangramento pela secção da artéria aorta abdominal. Pra tanto, foi realizada uma incisão longitudinal na região cérvico-ventral e a traquéia exposta e canulada com o auxílio de uma cânula metálica $(20 \mathrm{G})$, fixada com fio de algodão ao redor da traquéia. A cânula foi acoplada a uma seringa contendo $0,8 \mathrm{ml}$ de PBS que foi injetado no espaço alveolar e 
coletado em seguida em tubos plásticos. Após este procedimento, mais $0,7 \mathrm{ml}$ de PBS foi injetado e coletado, totalizando o volume de $1,5 \mathrm{ml}$ de LBA. O LBA obtido foi centrifugado por $3 \mathrm{~min}$ a $1500 \mathrm{rpm}$, o sobrenadante desprezado e o botão celular ressuspenso em $1 \mathrm{ml}$ de PBS. Alíquotas da amostra $(90 \mu \mathrm{l})$ foram acrescidas de $10 \mu \mathrm{l}$ de cristal violeta 0,2\% dissolvido em ácido acético (30\%) para a contagem do número total de células, que foi realizada em câmara de Neubauer, contando os 4 quadrantes. Para a contagem diferencial das células, alíquotas da amostra $(200 \mu 1)$ foram colocadas em citocentrífuga Citospin® (Fanem, Guarulhos, São Paulo, Brasil) e centrifugadas a 1.000 rpm por 5 minutos. As lâminas obtidas foram coradas utilizando-se o kit de corantes Instant Prov (Newprov®, Pinhais, Paraná, Brasil) (solução de ciclohexadienos a $0,1 \%$, solução de azobenzenosulfônicos a $0,1 \%$ e solução de fenotiazinas a $0,1 \%$ ). A contagem diferencial foi feita por microscopia de luz e contadas no mínimo 100 células, diferenciando-as segundo o tipo celular (células mononucleares, neutrófilos e eosinófilos).

\subsection{Determinação do número total de células na medula óssea}

Após obtenção do LBA, os mesmos animais tiveram o fêmur esquerdo cirurgicamente removido, ambas as extremidades abertas e o canal medular perfundido a partir da extremidade distal, pela introdução de uma agulha acoplada a uma seringa contendo $1 \mathrm{ml}$ de PBS. A suspensão medular foi homogeneizada como o auxilio de uma pipeta e a seguir as células totais foram contadas em câmara de Neubauer por microscopia de luz. Para tanto, 90 $\mu 1$ da amostra foram acrescidos de $10 \mu \mathrm{l}$ de cristal violeta, seguido de uma segunda diluição de 1:10 em PBS, para que as células pudessem ser expressas $\times 10^{6} / \mathrm{ml}$.

\subsection{Determinação do número de leucócitos circulantes}

Amostras de sangue também foram coletadas da aorta abdominal dos animais que tiveram o fêmur removido. Foi utilizada pipeta automática $(10 \mu \mathrm{l})$ para coletar a amostra, acrescida de $190 \mu \mathrm{l}$ de líquido de Türk (3\%). A quantificação do número total de células foi realizada em câmara de Neubauer por microscopia de luz. A contagem diferencial dos leucócitos circulantes foi realizada por esfregaço de sangue em lâmina de vidro, as quais foram coradas utilizando-se o "kit" de corantes Instant Prov (Neuprov®). A determinação do número diferencial de células foi realizada a partir da contagem de 100 células. As amostras 
de sangue coletadas que não foram utilizadas foram centifugadas por 3 minutos, o soro foi coletado e guardado em freezer para posterior análise.

\subsection{Análise histológica dos pulmões}

A análise histológica pulmonar foi baseada nos estudos de Kim (2010) e Faller (2012). Após a eutanásia e toracotomia, foi realizada a retirada dos pulmões dos animais. Os pulmões foram mantidos em solução fixadora de Bouin por 18 horas. Após a parafinização e emblocamento, o material foi cortado a $5 \mu \mathrm{m}$ de espessura e corado com hematoxilina e eosina para determinação da morfologia geral. Paralelamente o material foi também processado para análise das células de Goblet produtoras de muco e para a visualização de depósito de colágeno. Para tanto, o material foi corado com ácido periódico de Schiff (PAS) e picrossirius respectivamente, utilizando a metodologia descrita em Reinhard et al (2005).

\subsection{Coleta de sangue para obtenção do soro}

Após anestesia profunda, o sangue dos animais foi coletado da aorta abdominal, com o auxílio de seringa de $1 \mathrm{ml}$ e posteriormente centrifugado (1500 rpm/5 minutos em temperatura ambiente) para obtenção do soro. Este foi armazenado em eppendorfs de polietileno em freezer a $-80^{\circ} \mathrm{C}$ até o momento da realização das dosagens hormonais.

\subsection{Determinação da concentração de estradiol e progesterona no soro}

Amostras de soro dos animais foram retiradas do freezer e mantidas à temperatura ambiente para o descongelamento. As dosagens para a quantificação de estradiol e progesterona foram realizadas por radioimunoensaio em fase sólida utilizando-se o kit comercial Coat-a-Count (DPC, Los Angeles, CA, USA) específico. Os resultados dessas dosagens foram expressos em $\mathrm{pg} / \mathrm{ml}$ para o estrógeno e em $\mathrm{ng} / \mathrm{ml}$ para a progesterona.

\subsection{Quantificação da concentração de corticosterona no soro}

As amostras de soro dos animais foram retiradas do freezer e mantidas à temperatura ambiente para o descongelamento. As dosagens para a quantificação de corticosterona foram realizadas por ELISA utilizando-se o kit comercial Multi-espécie Enzo Life Sciences ELISA 
Assay (DPC, Los Angeles, CA, USA), com limite de detecção: 32 - 20,000 pg/mL e sensibilidade: $27.0 \mathrm{pg} / \mathrm{mL}$.

\subsection{Avaliação da reatividade de segmentos isolados de traquéia in vitro}

\subsubsection{Obtenção dos segmentos de traquéia}

Os animais receberam dose excessiva de cetamina e xilazina como descrito anteriormente, 24 horas após o último re-desafio. A cavidade peritoneal foi exposta e os animais submetidos à eutanásia por dessangramento pela secção da aorta abdominal. A seguir o tórax foi aberto e a traquéia cuidadosamente removida, dissecada (removidos os tecidos adjacentes) e um segmento de cerca de $2 \mathrm{~mm}$ de traquéia foi obtido.

\subsubsection{Avaliação da reatividade de traquéia}

Os segmentos de traquéia foram montados em anéis para registro isométrico das contrações. Com o auxílio de dois ganchos de aço que serviram de apoio, os anéis de traquéia, foram colocados em cuba de vidro para órgão isolado contendo $15 \mathrm{ml}$ solução de KrebsHenseleit (KHS) composta de (mM): $\mathrm{NaCl}, 115.0 ; \mathrm{KCl}, 4.6 ; \mathrm{CaCl}_{2} 2 \mathrm{H}_{2} \mathrm{O}, 2.5 ; \mathrm{KH}_{2} \mathrm{PO}_{4}, 1.2$; $\mathrm{MgSO}_{4} \cdot 7 \mathrm{H}_{2} \mathrm{O}, 2.5 ; \mathrm{NaHCO}_{3}, 25.0$; e glicose, 11.0. A solução KHS foi continuadamente gaseificada com $95 \%$ de $\mathrm{O}_{2}$ e $5 \%$ de $\mathrm{CO}_{2}$ e mantida aquecida a $37^{\circ} \mathrm{C}$. Os anéis de traquéia foram expostos a uma carga inicial de $500 \mathrm{mg}$ de tensão. Os anéis permaneceram em repouso nesta tensão por um período de 40 minutos para a estabilização. Durante este período de tempo a solução de KHS foi trocada a cada 15 minutos. Terminado o tempo da estabilização, a tensão foi reajustada para $500 \mathrm{mg}$ e a capacidade contrátil dos anéis de traquéia (viabilidade) foi avaliada substituindo o tampão KHS por tampão $\mathrm{KCl}$ despolarizante $(60 \mathrm{mM})$. Após a avaliação da viabilidade das preparações, o $\mathrm{KCl}$ foi novamente substituído pelo tampão KHS. Decorridos 20 minutos de equilíbrio foram administradas nas cubas doses crescentes e logarítmicas de metacolina ( $\mathrm{MCh}, 10^{-9}$ a $10^{-3} \mathrm{M}$ ) para construção das curvas concentraçãoefeito cumulativas. Os dados foram capturados por transdutores isométricos (F-60, Mulrany) acoplados ao sistema PowerLab 4sp e posteriormente analisados utilizando o programa LabChart 7.3.1 (AD Instruments ${ }^{\circledR}$, Austrália). 
Figura 2- Fotografias do aparelho utilizado para a avaliação da reatividade traqueal
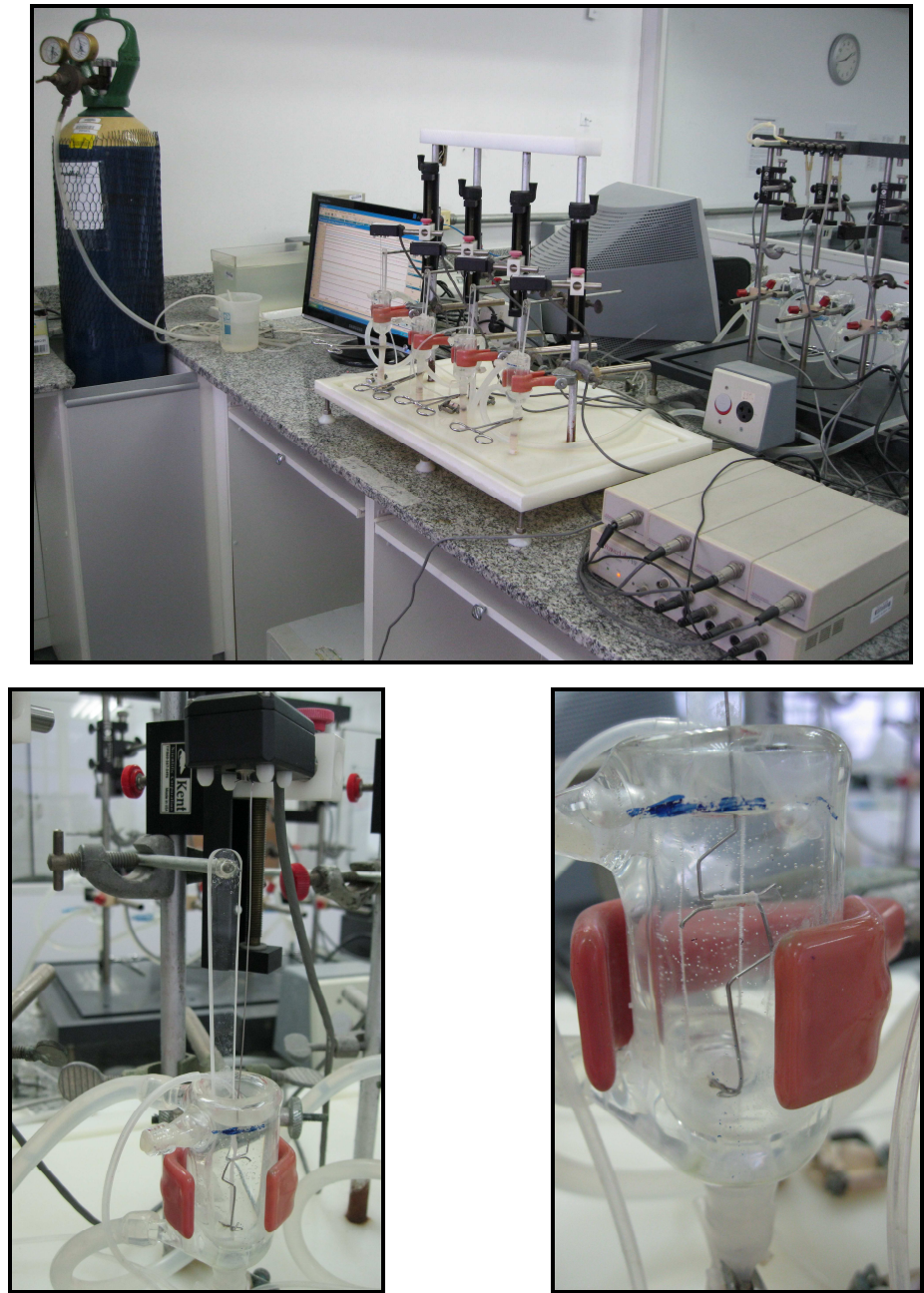

Podemos observar na primeira imagem todos os componentes do equipamento. Na seguinte, observamos o transdutor isométrico e a montagem do tecido traqueal e na terceira fotografia observamos a preparação do tecido dentro da cuba. Fonte: arquivo próprio.

\subsection{Avaliação da mecânica respiratória}

A metodologia foi baseada como descrita em Collins (2003). Os animais foram anestesiados como descrito previamente. Para a traqueostomia, foi realizada uma incisão longitudinal na região cérvico-ventral, a traquéia foi exposta e uma cânula metálica $(18 \mathrm{G})$ foi introduzida no orifício da traqueostomia, fixada ao redor da traquéia com fio de algodão. Posteriormente, os animais foram conectados por meio da cânula ao aparelho de ventilação mecânica para pequenos animais (flexiVent, SCIREQ ${ }^{\circledR}$, Montreal, Quebec, Canadá) e submetidos à ventilação pulmonar com volume corrente a $10 \mathrm{ml} / \mathrm{kg}$ e freqüência respiratória (FR) de 450 ciclos/minuto. A PEEP (pressão positiva no final da expiração) foi mantida em 3 $\mathrm{cmH}_{2} \mathrm{O}$, conectada à válvula expiratória do ventilador. Logo após o início da ventilação mecânica, os animais foram submetidos a manobras de recrutamento pulmonar, i.e, os 
pulmões foram insuflados a partir da capacidade residual funcional até uma pressão de 30 $\mathrm{cmH}_{2} \mathrm{O}$ e mantidos nessa pressão por 3 segundos, a fim de homogeneizar todo o histórico pulmonar e aerar possíveis regiões atelectasiadas. Foi avaliada a responsividade pulmonar do animal à concentração de $50 \mathrm{mg} / \mathrm{ml}$ de metacolina diluída em PBS - phosphate buffered saline) que foram oferecidas na forma de aerossol pela traquéia do animal durante 10 segundos, por um nebulizador por micro-bombeamento (Aeroneb ${ }^{\circledR}$, Aerogen). Como controle foi utilizada somente a solução fisiológica, antes da administração de MCh. A coleta dos dados de resistência e elastância foram realizadas 15 segundos após o término da nebulização de cada concentração de $\mathrm{MCh}$, e houve intervalo de 5 minutos entre a inalação de uma concentração e outra de MCh. Para a obtenção dos dados de resistência e elastância do sistema respiratório total foi utilizado o modelo unicompartimental (BATES, 1998) que considera o sistema respiratório como um único compartimento (pulmão e caixa torácica) e utiliza a equação do movimento, no tempo:

$$
P=R_{r g} \cdot V^{\prime}+E_{r g} \cdot V+P_{0}
$$

onde $P$ é a pressão na entrada das vias aéreas, $R_{r g}$ é a resistência do sistema respiratório, $V^{\prime}$ é o fluxo calculado pela derivada do volume, $E_{r g}$ é a elastância do tecido pulmonar, $V$ é o volume e $P_{0}$ é a constante de correção de erros da capacidade residual funcional. Os parâmetros que foram avaliados por este modelo foram $R_{r q}$ (resistência do sistema respiratório) e $E_{r g}$ (elastância do tecido pulmonar).

Findo o experimento, o animal foi submetido à eutanásia por meio da secção da aorta abdominal (dessangramento) e então desconectado do aparelho. Os dados foram capturados e analisados pelo software flexiVent, versão 5.2. 
Figura 3- Fotografias do aparelho utilizado para a avaliação da mecânica pulmonar.
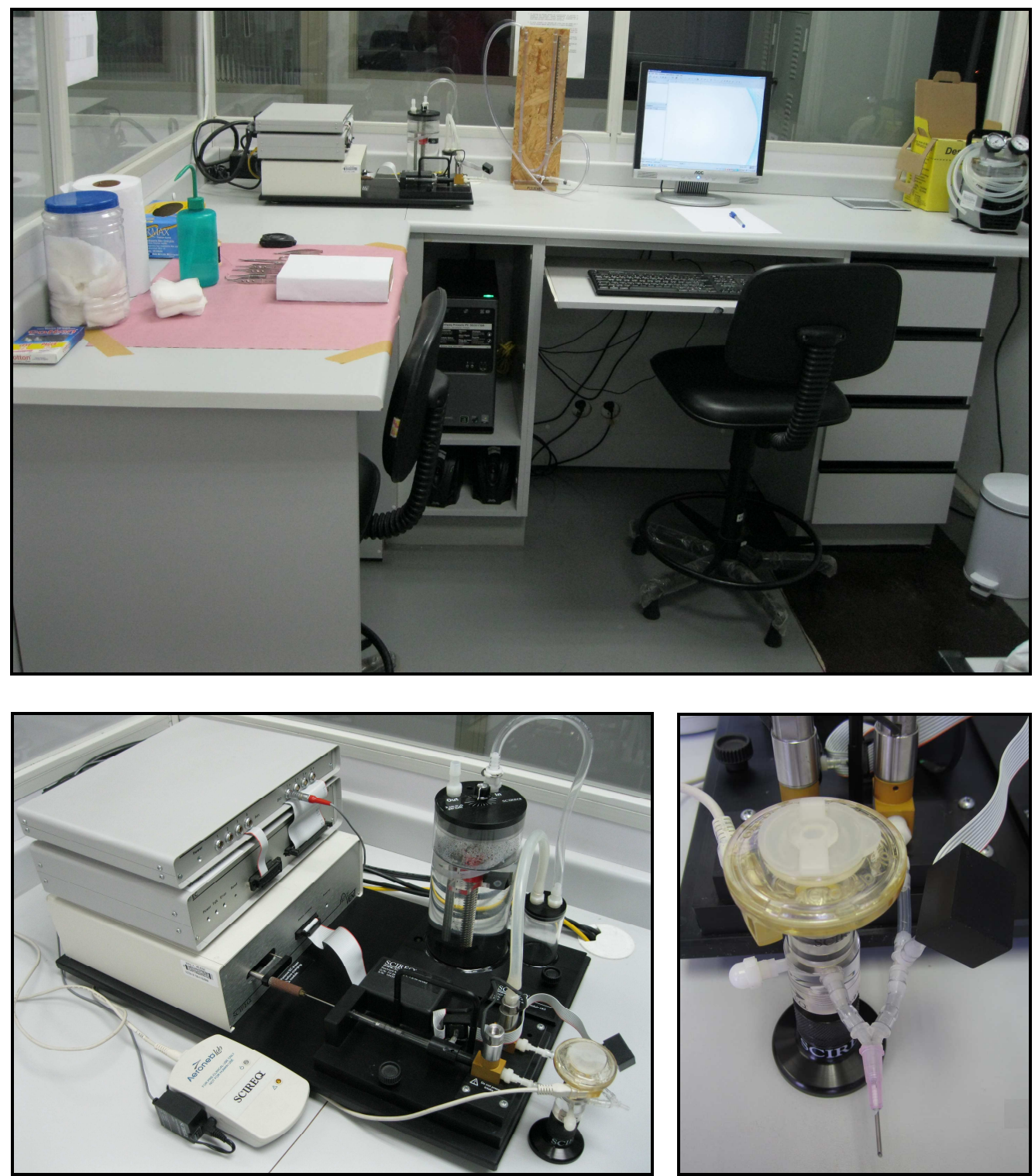

Podemos observar na primeira imagem a sala com todos os equipamentos utilizados no experimento. Na seguinte, observamos o ventilador mecânico para pequenos animais (flexiVent) e na terceira fotografia observamos a cânula que conecta o animal ao aparelho. Fonte: arquivo próprio. 


\subsection{Cultura de fragmentos de pulmão isolado (explante)}

O explante pulmonar foi realizado de acordo com o descrito por Proust et al. (2003). Em síntese, os fragmentos foram coletados após perfusão intravascular dos pulmões com $5 \mathrm{ml}$ de PBS para remoção do conteúdo intravascular (Tavares de Lima et al., 1998). A seguir, os fragmentos de igual peso do mesmo lobo pulmonar foram incubados em placas plásticas de 24 poços contendo DMEM (1 ml) suplementado com $1 \%$ de L-glutamina e gentamicina (10 $\mu \mathrm{g} / \mathrm{ml}$ ) a $37{ }^{\circ} \mathrm{C}$ em atmosfera úmida contendo $5 \%$ de $\mathrm{CO}_{2}$. Como controle foram utilizados fragmentos de pulmão de animais do grupo não manipulado (basais).

\subsection{Quantificação de mediadores inflamatórios}

As citocinas IL-4, IL-5 e IL-10 foram quantificadas em alíquotas de sobrenadante de explante pulmonar por MULTIPLEX, por meio de Kits Duo Set disponíveis comercialmente (R \& D System). Em síntese, o filtro da placa de 96 poços foi lavado com Bioplex Assay Buffer (Bio Rad, Hercules, CA). Em seguida, foram adicionados as "beads" conjugadas com anticorpos anti-citocinas, lavados com "Bioplax Wash Buffer", sendo posteriormente adicionadas as amostras do explante. Seguido de uma incubação de 2 horas, a placa foi novamente lavada com o "Bioplex Wash Buffer", sendo então adicionado a cada poço o anticorpo de detecção biotinilado para um epítopo diferente da citocina, formando então um sanduíche de anticorpos, incubados por 1hora. Após esse período, novas lavagens com o "Bioplex Wash Buffer" foram realizadas, sendo então adicionada estreptavidina conjugada com PE, que se liga ao anticorpo biotinilado, por 30 minutos. Novas lavagens foram realizadas e as "beads" foram ressuspensas com Bioplex Assay Buffer e analisadas no Bioplex 200 Suspension Array System/ Luminex (Bio Rad, Hercules, CA) por meio do Software Bio-Plex Manager, versão 4.1 (Bio Rad, Hercules, CA). Os dados apresentados são referentes no mínimo 100 beads por citocina.Os ensaios foram conduzidos seguindo as especificações do fabricante.

\subsection{Quantificação de nitritos $\left(\mathrm{NO}_{2}\right)$ em amostras de explante pulmonar}

A produção de nitritos foi determinada de acordo com o método de Griess. O ensaio foi realizado pela adição de $50 \mu \mathrm{l}$ de sobrenadante de cultura pulmonar (obtida por meio do explante pulmonar) em placas de 96 poços contendo o mesmo volume do reagente de Griess 
em temperatura ambiente por 10 minutos. Como grupo controle foram utilizados cultura de explante pulmonar de animais não manipulados (basais). A densidade óptica $(50 \mathrm{~nm})$ foi obtida utilizando o leitor de Elisa automático (Bio Tek instruments ${ }^{\circledR}$ ) e o nível de nitrito foi determinado utilizando a curva padrão previamente estabelecida de $\mathrm{NaNO}_{2}(5 \mu \mathrm{m}-60 \mu \mathrm{m})$.

\subsection{Análise estatística}

Os dados das amostras foram submetidos à análise de variância (ANOVA) seguido do teste Student Newman-keuls para amostras não pareadas. As análises estatísticas foram conduzidas utilizando GraphPad Prism Software v.4 (2005). Os resultados foram expressos como média \pm erro padrão da média $(\mathrm{EPM})$. Valores de $\mathrm{P}<0,05$ foram considerados significantes. 


\section{RESULTADOS}

\subsection{Efeito da remoção dos ovários sobre a massa uterina e ciclo estral}

A figura 4 mostra os valores obtidos da quantificação da massa uterina de animais alérgicos 10 dias após a remoção dos ovários (OVx), isto é, 24 horas após o último re-desafio. Como pode ser observado, a massa uterina dos animais do grupo alérgico OVx reduziu significantemente em relação à dos animais do grupo falsamente operado (alérgico Sham/OVx). O tratamento dos animais alérgicos ovariectomizados com estrógeno e também aqueles tratados com estrógeno e progesterona juntos restabeleceu a massa uterina aos valores encontrados no útero dos animais alérgicos Sham/OVx. Em contrapartida, o tratamento dos animais alérgicos OVx com progesterona não promoveu aumento da massa uterina.

Paralelamente, analisamos as células presentes no lavado vaginal desses animais. Nas fotomicrografias a seguir (Figura 5) observamos as características dessas células em cada fase do ciclo estral dos animais com ovários intactos e 10 dias após a remoção dos ovários. No proestro (Figura 5A) o lavado vaginal é composto por células epiteliais nucleadas, frequentemente de aparência granulosa. No estro (Figura 5B) observamos a presença de células anucleadas ou queratinizadas. O metaestro (Figura 5C), também chamado de diestro 1, caracteriza-se pela presença de células anucleadas, nucleadas e leucócitos. Na fase de diestro (Figura 5D) encontramos basicamente leucócitos.

A fotomicrografia 5E mostra o lavado vaginal de um animal após 10 dias da ovariectomia, que culminou com a indução e manutenção da fase de diestro, onde há reduzida concentração de hormônios sexuais circulantes e predomínio de leucócitos. Por fim, no lavado vaginal dos animais alérgicos $\mathrm{OVx}$ tratados com estrógeno observamos o predomínio de células nucleadas, caracterizando a fase denominada proestro; no lavado vaginal dos animais tratados com progesterona observamos a presença de células anucleadas, nucleadas, leucócitos e muco, determinando a fase de metaestro em transição para o diestro. O lavado vaginal dos animais tratados com ambos os hormônios (estrógeno + progesterona) apresentou-se composto de células anucleadas, nucleadas e leucócitos, caracterizando a fase de metaestro (figura $5 \mathrm{~F}, 5 \mathrm{G}$ e $5 \mathrm{E}$ ). 
Figura 4- Determinação da massa uterina após a remoção dos ovários.

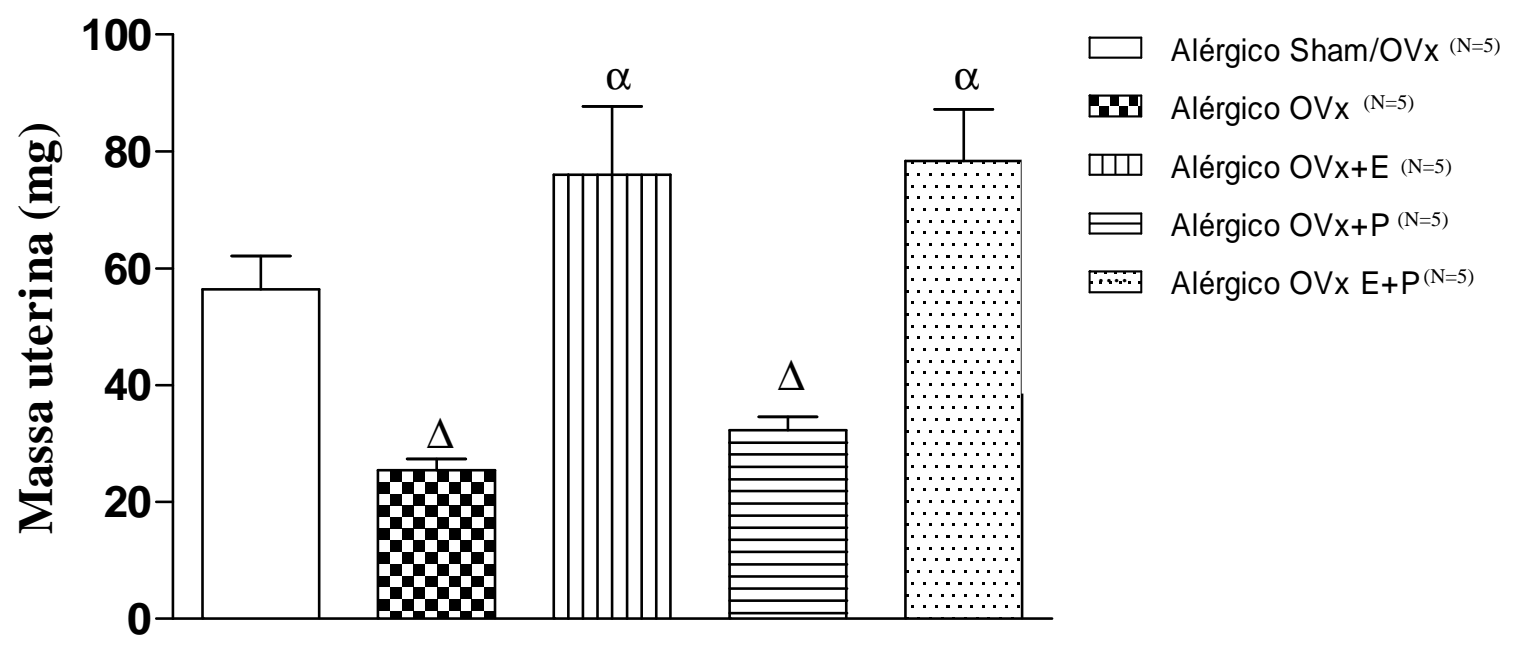

Os grupos consistiram de animais não manipulados (basal), animais sensibilizados, desafiados com OVA posteriormente ovariectomizados e novamente desafiados com OVA, animais sensibilizados, desafiados com OVA posteriormente ovariectomizados, tratados com estrógeno ou progesterona ou ambos e novamente desafiados com OVA e como controle foram utilizadas camundongos fêmeas sensibilizadas e desafiadas com OVA e posteriormente submetidos à falsa cirurgia de remoção dos ovários (Sham) e novamente desafiadas com OVA. Decorridos $24 \mathrm{~h}$ do último desafio os animais foram submetidos à eutanásia, o útero retirado e o seu peso determinado. Os dados representam a média \pm EPM de 5 animais. ${ }^{\Delta} \mathrm{p}<$ 0,05 em relação ao grupo alérgico Sham/OVx e ${ }^{\alpha} \mathrm{p}<0,05$ em relação ao grupo alérgico OVx. 
Figura 5 - Fotomicrografias das fases do ciclo estral de camundongos fêmeas e de um animal 10 dias após a remoção dos ovários.
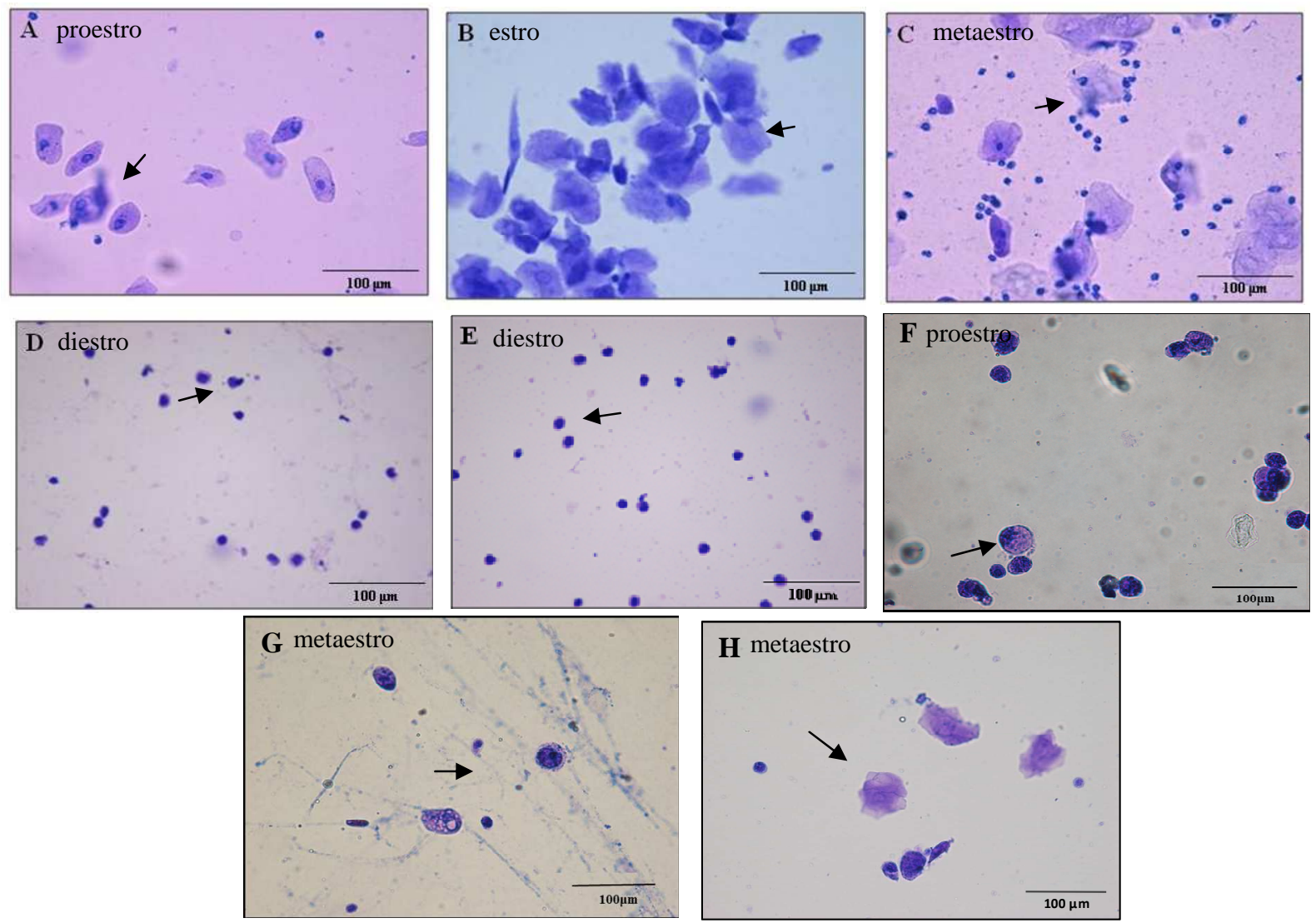

Em (A) proestro, caracterizado pelo predomínio de células nucleadas, em (B) estro, caracterizado pelo predomínio de células anucleadas, em (C) metaestro, caracterizado por diferentes tipos celulares e em (D) diestro, fase em que são encontrados apenas leucócitos. Em (E) está representada a fotomicrografia do lavado vaginal de um animal 10 dias após a remoção dos ovários, que culminou na indução e manutenção da fase de diestro, onde há predominância de leucócitos. Em F (proestro), em G (metaestro) e em H (metaestro) estão representados os animais ovariectomizados tratados com estrógeno, progesterona ou ambos, respectivamente. As células foram coradas com azul de metileno (5\%) e analisadas em microscópio óptico comum em aumento de 40x. 


\subsection{Efeito da remoção dos ovários sobre a concentração circulante de estradiol e progesterona}

Como pode ser observado na figura 6 (painel A), o grupo alérgico OVx apresentou redução dos níveis plasmáticos de estrógeno em relação ao grupo alérgico Sham/OVx. O tratamento com estrógeno e também com estradiol + progesterona restabeleceu os valores encontrados nos animais alérgicos Sham/OVx. O mesmo se observou com respeito à progesterona, pois podemos observar no painel B que o grupo alérgico OVx teve redução significante desse hormônio quando comparado ao grupo alérgico Sham/OVx. Os animais tratados com progesterona ou com estrógeno + progesterona tiveram a concentração destes hormônios restabelecida (painel B).

Figura 6 - Determinação dos níveis plasmáticos de estradiol e progesterona.
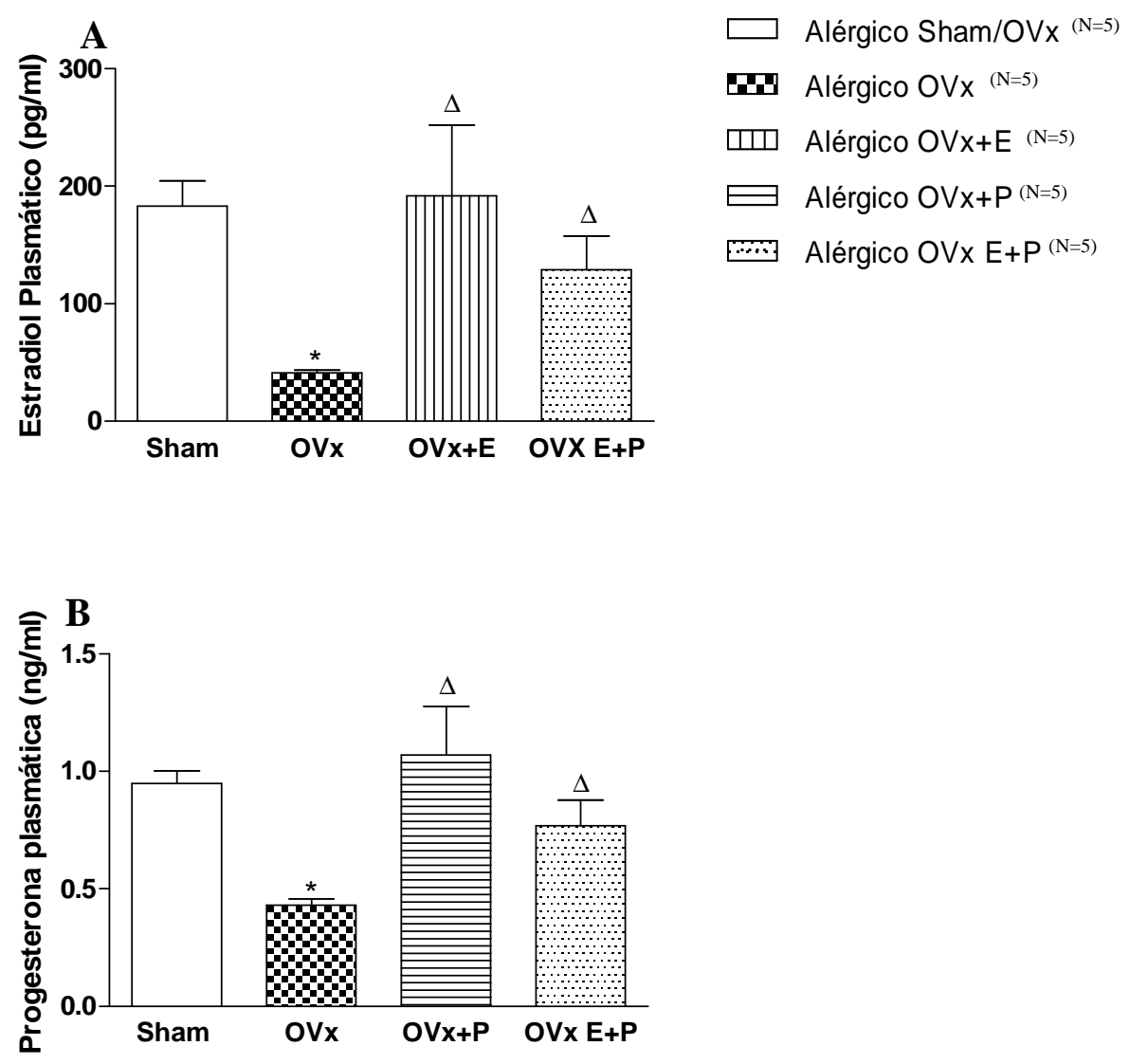

Os grupos consistiram de animais sensibilizados, desafiados com OVA posteriormente ovariectomizados e novamente desafiados com OVA; animais sensibilizados, desafiados com OVA posteriormente ovariectomizados, tratados com estrógeno e/ou progesterona e novamente desafiados com OVA e como controle foram utilizadas camundongos fêmeas sensibilizadas e desafiadas com OVA e posteriormente submetidos à falsa cirurgia de remoção dos ovários (sham) e novamente desafiadas com OVA. Decorridos $24 \mathrm{~h}$ do último desafio os animais foram eutanasiados e o lavado femural realizado. Os dados representam a média \pm EPM de 5 animais. ${ }^{*} \mathrm{p}<0,05$ em relação ao grupo alérgico Sham/OVx e ${ }^{\Delta} \mathrm{p}<$ 0,05 em relação ao grupo alérgico OVx. 


\subsection{Efeito do re-desafio com antígeno sobre o número de células presentes no lavado broncoalveolar $(\mathrm{LBA})$ de animais alérgicos}

De maneira a caracterizar a resposta alérgica pulmonar, determinamos o número de células presentes no LBA dos animais 24h após a última sessão de broncoprovocação e paralelamente, em um grupo adicional, no dia em que seria realizada a cirurgia de remoção dos ovários.

Observamos por meio da figura 7 (painel A), que a broncoprovocação com ovoalbumina por duas vezes, antes e após a falsa cirurgia de remoção dos ovários, aumentou as células presentes no LBA dos animais Sham/OVx em relação ao observado nos animais basais. É importante salientar que no dia da ovariectomia, os pulmões dos os animais já estavam inflamados devido ao aumento do número de células totais recuperadas no lavado broncoalveolar decorrente da primeira bateria de desafios com ovalbumina (painel B).

Observamos ainda que a remoção dos ovários associada ao re-desafio com OVA aumentou ainda mais o número de células presentes no LBA do grupo alérgico OVx em relação ao observado nos animais do grupo alérgico Sham/OVx. Todavia, o número de células totais no lavado broncoalveolar dos animais alérgicos OVx foi similar ao observado nos animais que passaram somente pela primeira bateria de desafios e foram e eutanasiados no dia da ovariectomia (figura 7, painel B).

$\mathrm{O}$ tratamento dos animais alérgicos $\mathrm{OVx}$ com estrógeno seguido do re-desafio foi acentuou ainda mais o aumento do número de células recuperadas no LBA destes animais em comparação ao observado nos animais alérgicos OVx. Vale lembrar que o tratamento dos animais alérgicos $\mathrm{OVx}$ com progesterona não alterou o número de células presentes no LBA destes animais, permanecendo com valores similares aos encontrados no LBA dos animais alérgicos OVx re-desafiados.

Por outro lado, o tratamento dos animais com estrógeno + progesterona reduziu o número de células recuperadas no LBA dos animais a valores semelhantes ao encontrados nos animais alérgicos Sham/OVx.

Com relação à análise diferencial (figura 8), observamos que apenas o tratamento dos animais com estrógeno aumentou significantemente o número de neutrófilos recuperados no LBA dos animais (figura 8A).

Os animais alérgicos que tiveram seus ovários removidos e posteriormente foram expostos ao re-desafio com OVA (grupo alérgico OVx) apresentaram aumento significante de eosinófilos no LBA, o qual se elevou ainda mais após o tratamento dos animais com 
estrógeno. O tratamento com progesterona ou com estrógeno+progesterona diminuiu o número de eosinófilos no lavado broncoalveolar em comparação aos animais alérgicos $\mathrm{OVx}$ (figura 8B).

Observamos ainda que o re-desafio dos animais alérgicos OVx não alterou o número de células mononucleares recuperadas do LBA em relação ao observado nos animais alérgicos Sham/OVx. Embora o tratamento com estrógeno ou com progesterona isoladamente elevou o número destas células no LBA, o tratamento com estrógeno + progesterona não causou diferença no número de mononucleares no LBA quando comparados aos animais alérgicos OVx não tratados.

Figura 7 - Efeito da ovariectomia (OVx) sobre o número total de células do LBA 24 h após a última broncoprovocação.

LBA

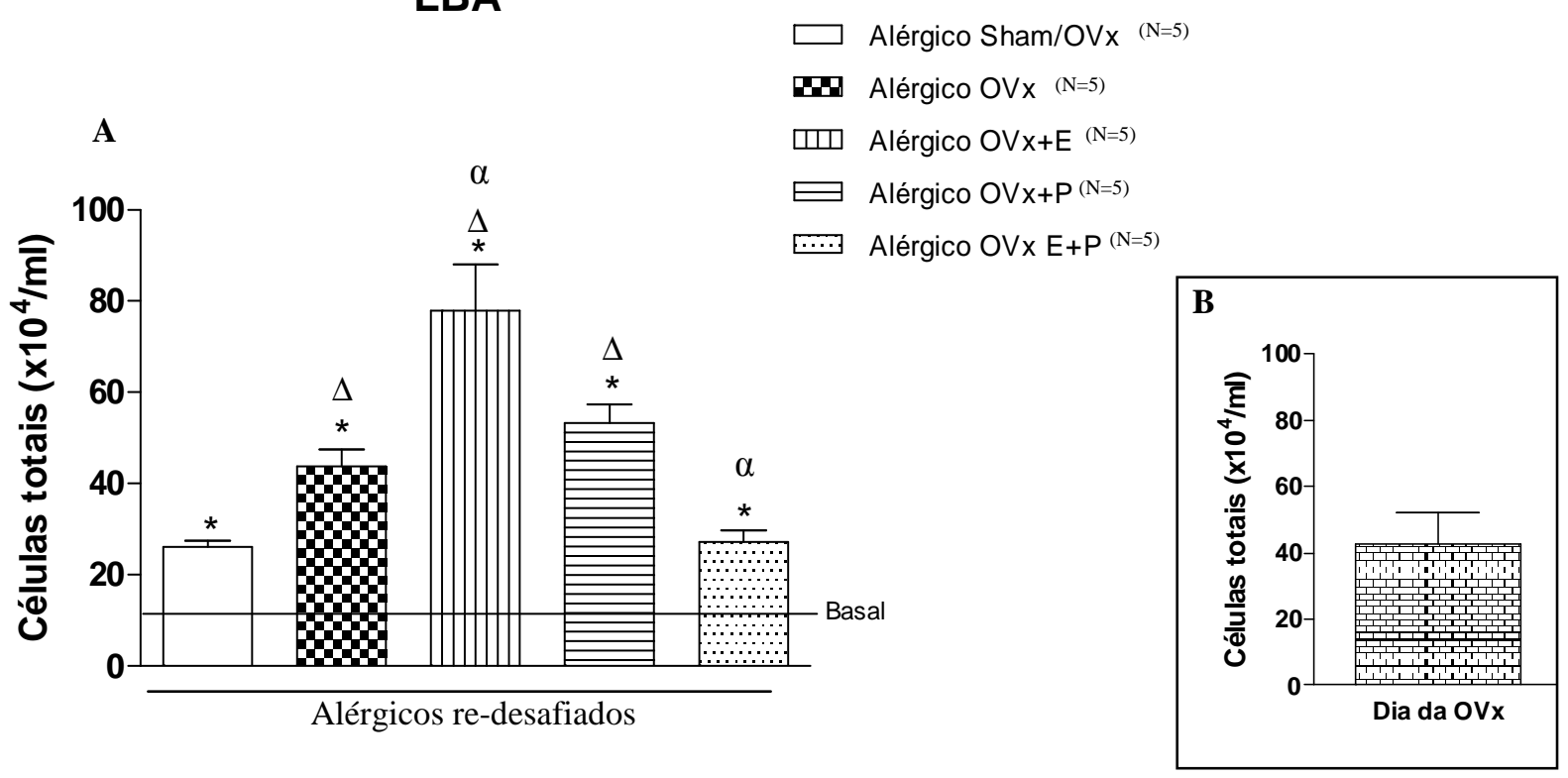

Os grupos consistiram de painel A - animais não manipulados (basal), animais sensibilizados, desafiados com OVA posteriormente ovariectomizados e novamente desafiados com OVA, animais sensibilizados, desafiados com OVA posteriormente ovariectomizados, tratados com estrógeno e/ou progesterona e novamente desafiados com OVA e como controle foram utilizadas camundongos fêmeas sensibilizadas e desafiadas com OVA e posteriormente submetidos à falsa remoção dos ovários (sham) e novamente desafiadas com OVA. Decorridos $24 \mathrm{~h}$ do último desafio os animais foram eutanasiados e o LBA realizado. Os dados representam a média \pm EPM de 5 animais. ${ }^{*} \mathrm{p}<0,05$ em relação ao grupo basal ${ }^{\Delta} \mathrm{p}$ $<0,05$ em relação ao grupo alérgico Sham/OVx; ${ }^{\alpha} \mathrm{p}<0,05$ em relação ao grupo alérgico OVx. Painel $\mathrm{B}-$ animais sensibilizados e desafiados com OVA. 
Figura 8 - Efeito da ovariectomia sobre o número de neutrófilos (A), eosinófilos (B) e células mononucleares $(\mathrm{C})$ presentes no LBA 24 h após a última broncoprovocação.

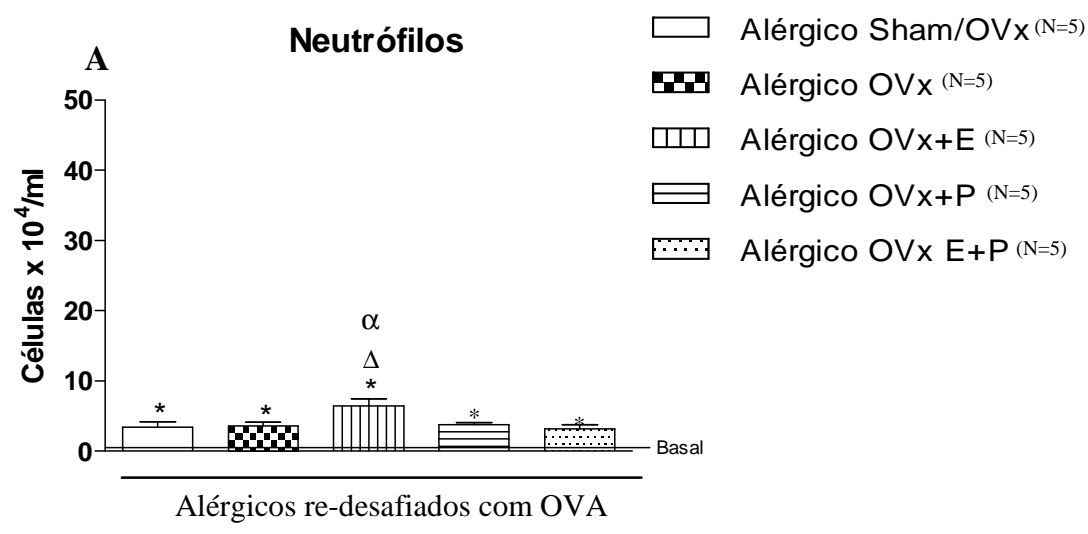

\section{Eosinófilos}
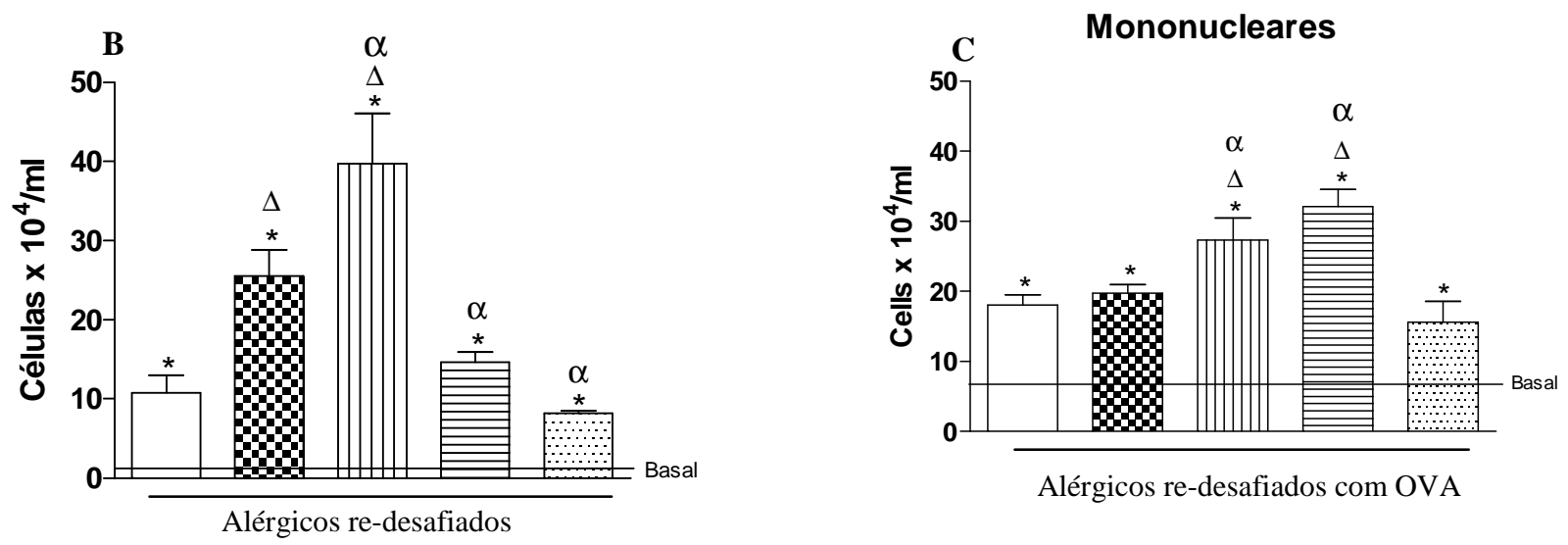

Os grupos consistiram de animais não manipulados (basal), animais sensibilizados, desafiados com OVA posteriormente ovariectomizados e novamente desafiados com OVA, animais sensibilizados, desafiados com OVA posteriormente ovariectomizados, tratados com estrógeno e/ou progesterona e novamente desafiados com OVA e como controle foram utilizadas camundongos fêmeas sensibilizadas e desafiadas com OVA e posteriormente submetidos à falsa remoção dos ovários (sham) e novamente desafiadas com OVA. Decorridas 24 h do último desafio os animais foram eutanasiadas e o LBA realizado. Os dados representam média \pm EPM de 5 animais. ${ }^{\Delta} \mathrm{p}<0,05$ em relação ao grupo alérgico Sham/OVx; ${ }^{\alpha} \mathrm{p}<0,05$ em relação ao grupo alérgico $\mathrm{OVx}$.

Adicionalmente, a figura 9 mostra as imagens obtidas das lâminas confeccionadas com amostras do LBA, representadas anteriormente no histograma.

É interessante mostrar mais uma vez, agora por meio das fotomicrografias, o aumento do infiltrado celular nos pulmões dos animais submetidos ao re-desafio alérgico, onde a imagem mostra o acúmulo de células. Já nas imagens que representam o LBA dos animais alérgicos OVx e daqueles tratados com estrógeno, podemos verificar além do aumento das células totais, que o infiltrado celular se compõe em sua grande maioria de eosinófilos. 
Figura 9 - Infiltrado celular das vias aéreas obtido pela coleta do LBA em aumento de 40x.
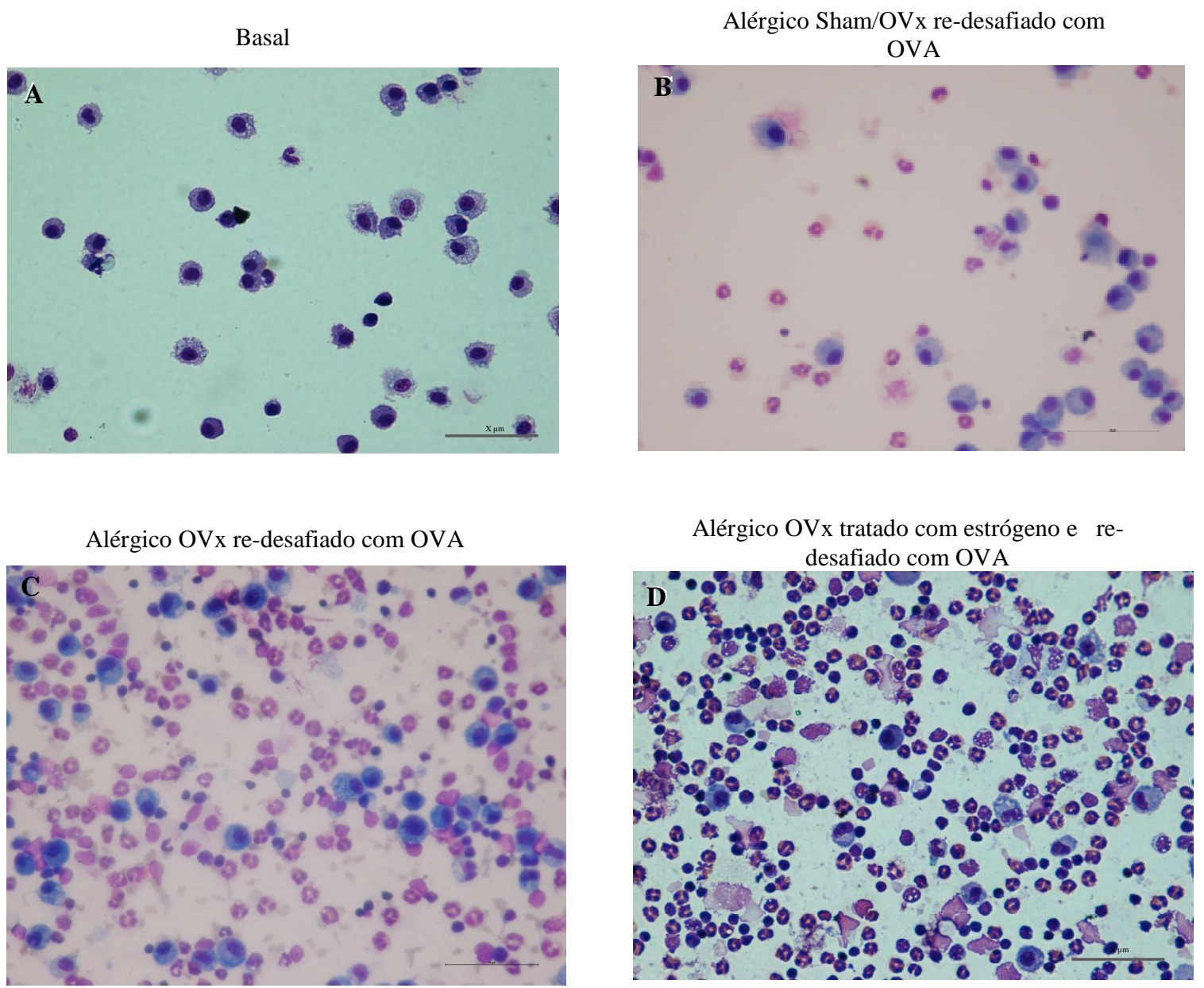

Alérgico OVx tratado com progesterona e redesafiado com OVA

Alérgico OVx tratado com estrógeno e progesterona e re-desafiado com OVA
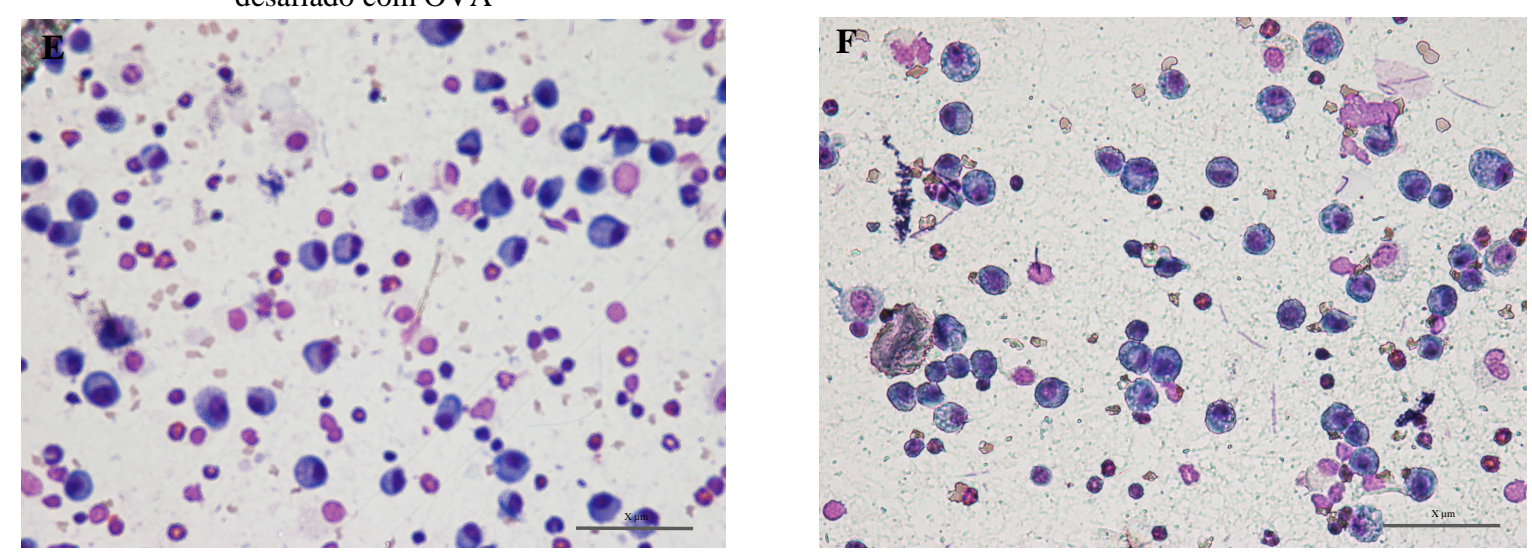

Os leucócitos recuperados do LBA foram corados com kit insant prov, como descrito anteriormente. Painel A: basal, painel $\mathrm{B}$ : alérgico Sham/OVx, painel C: alérgico $\mathrm{OVx}$, painel $\mathrm{D}$ : tratado com estrógeno, painel E: tratado com progesterona, painel F: tratado com estrógeno e progesterona. 


\subsection{Efeito do re-desafio com antígeno em animais alérgicos sobre o número de leucócitos circulantes após broncoprovocação com ovoalbumina (OVA)}

Os dados representados na figura 10 mostram que o re-desafio dos animais alérgicos OVx determinou redução significante do número total de células circulantes em relação ao grupo controle alérgico Sham/OVx. Por outro lado, observamos que o tratamento dos animais OVx com estrógeno ou com progesterona seguido do re-desafio causou aumento do número destas células. O tratamento com estrógeno + progesterona, por sua vez, determinou aumento dos leucócitos circulantes em relação aos alérgicos $\mathrm{OVx}$, mas este aumento foi menor que o observado nos animais tratados com estrógeno ou com progesterona, levando a valores similares ao observado nos animais alérgicos Sham/OVx. No que se refere à análise diferencial das células circulantes, observamos que a remoção dos ovários dos animais alérgicos e a re-exposição destes animais à OVA (grupo alérgico OVx) culminou na redução do número de células mononucleares (monócitos e linfócitos) quando comparados ao grupo dos animais alérgicos, mas com os ovários intactos (alérgico Sham/OVx). O tratamento dos animais OVx com estrógeno ou com estrógeno + progesterona aumentou o número de células mononucleares circulantes em relação aos animais sem ovários e sem tratamento (alérgicos OVx). Ainda assim, o tratamento com progesterona causou aumento maior das células mononucleares circulantes em relação ao observado nos animais alérgicos OVx (figura 11).

Com relação às polimorfonucleares (neutrófilos e eosinófilos), observamos que apenas os animais do grupo tratado com estrógeno apresentaram significante aumento do número dessas células. 
Figura 10 - Efeito da ovariectomia (OVx) sobre o número total de leucócitos circulantes 24 h após a última broncoprovocação.

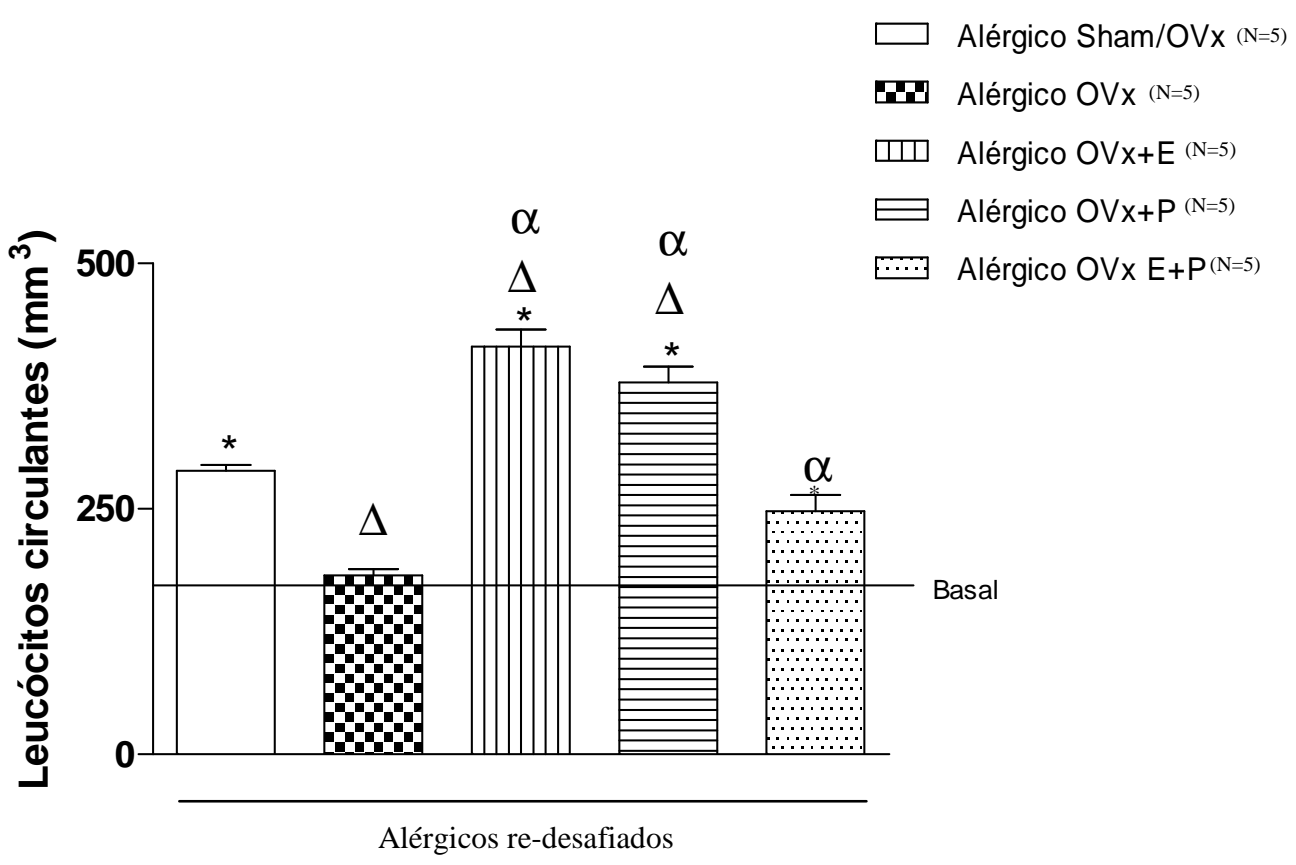

Os grupos consistiram de animais não manipulados (basal), animais sensibilizados, desafiados com OVA posteriormente ovariectomizados e novamente desafiados com OVA, animais sensibilizados, desafiados com OVA posteriormente ovariectomizados, tratados com estrógeno e/ou progesterona e novamente desafiados com OVA e como controle foram utilizadas camundongos fêmeas sensibilizadas e desafiadas com OVA e posteriormente submetidos à falsa cirurgia de remoção dos ovários (sham) e novamente desafiadas com OVA. Decorridos $24 \mathrm{~h}$ do último desafio os animais foram eutanasiados e o sangue coletado. Os dados representam a média \pm EPM de 5 animais. ${ }^{\Delta} \mathrm{p}<0,05$ em relação ao grupo alérgico sham/OVx; ${ }^{\alpha} \mathrm{p}<0,05$ em relação ao grupo alérgico $\mathrm{OVx}$. 
Figura 11 - Efeito da ovariectomia sobre o número de células mononucleares (a) e polimorfonucleares (b) presentes no sangue e recuperadas 24 hs após a última broncoprovocação
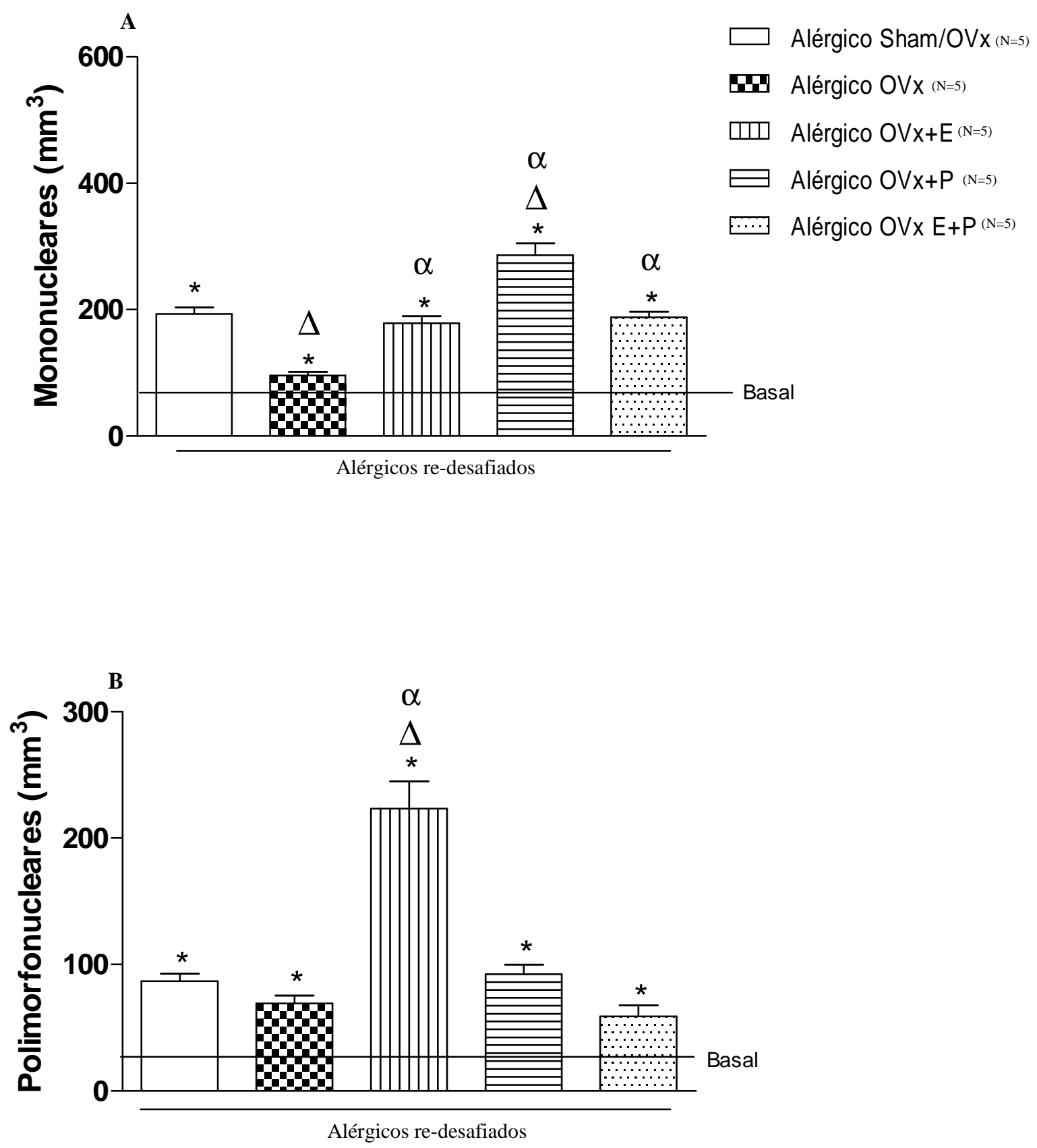

Os grupos consistiram de animais não manipulados (basal), animais sensibilizados, desafiados com OVA posteriormente ovariectomizados e novamente desafiados com OVA, animais sensibilizados, desafiados com OVA posteriormente ovariectomizados, tratados com estrógeno e/ou progesterona e novamente desafiados com OVA e como controle foram utilizadas camundongos fêmeas sensibilizadas e desafiadas com OVA e posteriormente submetidos à falsa cirurgia de remoção dos ovários (sham) e novamente desafiadas com OVA. Decorridos $24 \mathrm{~h}$ do último desafio os animais foram eutanasiados e o sangue coletado. Os dados representam a média \pm EPM de 5 animais. ${ }^{\Delta} \mathrm{p}<0,05$ em relação ao grupo alérgico Sham/OVx; ${ }^{\alpha} \mathrm{p}<0,05$ em relação ao grupo alérgico $\mathrm{OVx}$. 


\subsection{Efeito do re-desafio com antígeno em animais alérgicos sobre o número de células presentes no lavado de medula óssea (LM)}

Na figura 12 observamos redução do número de células presentes no lavado da medula óssea dos animais do grupo alérgico Sham/OVx em relação aos animais basais. O re-desafio dos animais alérgicos ovariectomizados aumentou o número de células obtidas da medula óssea em relação aos alérgicos Sham/OVx. O tratamento dos animais com estrógeno ou progesterona seguido do re-desafio reduziu o número de células da medula óssea destes animais quando comparado ao dos animais alérgicos OVx. O tratamento dos animais alérgicos OVx com ambos os hormônios reduziu ainda mais o número dessas células.

Figura 12 - Efeito da ovariectomia (OVx) sobre o número total de células da medula óssea 24h após a última broncoprovocação.

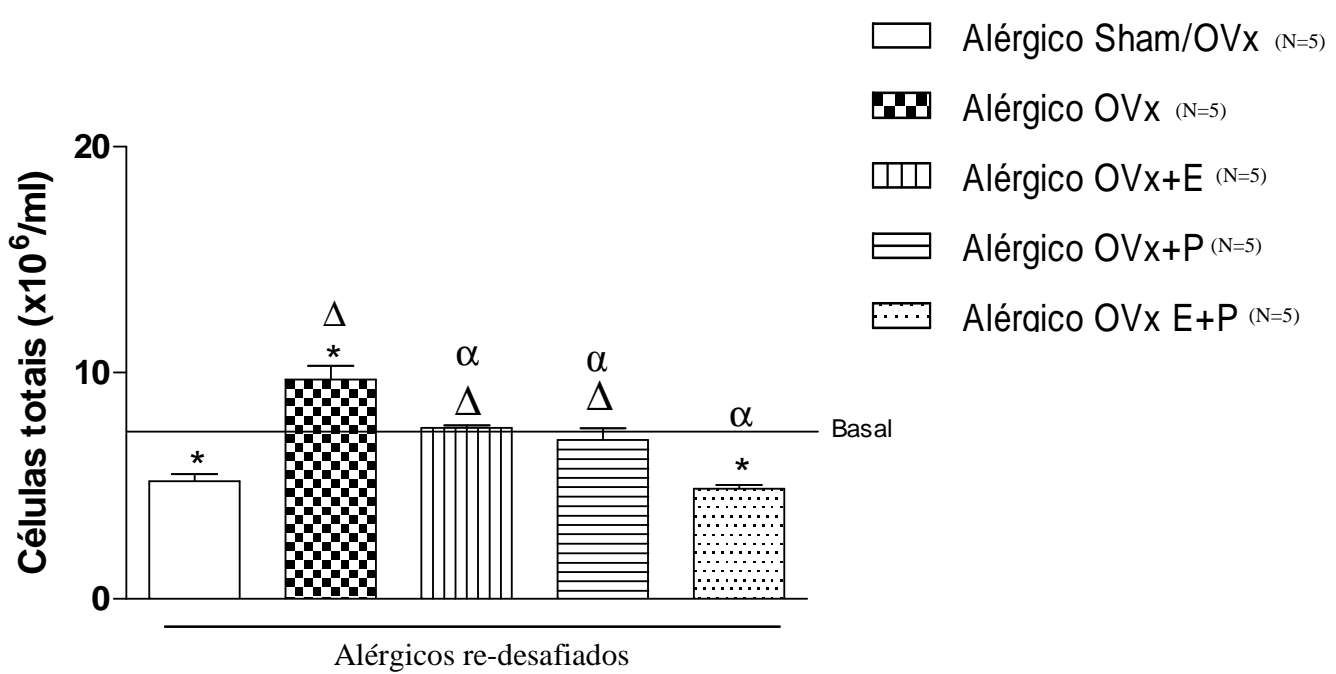

Os grupos consistiram de animais não manipulados (basal), animais sensibilizados, desafiados com OVA posteriormente ovariectomizados e novamente desafiados com OVA, animais sensibilizados, desafiados com OVA posteriormente ovariectomizados, tratados com estrógeno e/ou progesterona e novamente desafiados com OVA e como controle foram utilizadas camundongos fêmeas sensibilizadas e desafiadas com OVA e posteriormente submetidas à falsa cirurgia de remoção dos ovários (Sham) e novamente desafiadas com OVA. Decorridos $24 \mathrm{~h}$ do último desafio os animais foram eutanasiados e o lavado femural realizado. Os dados representam a média \pm EPM de 5 animais. ${ }^{\Delta} \mathrm{p}<0,05$ em relação ao grupo alérgico Sham/OVx; ${ }^{\alpha} \mathrm{p}<0,05$ em relação ao grupo alérgico $\mathrm{OVx}$. 


\subsection{Efeito do re-desafio com antígeno em animais alérgicos sobre a produção de muco, colágeno e a migração celular - Análise histológica dos pulmões}

A figura 13 apresenta o corte histológico de pulmão de animais do grupo basal (A), alérgico Sham/OVx (B), Alérgico OVx (C), Alérgico OVx tratado com estrógeno (D), Alérgico $\mathrm{OVx}$ tratado com progesterona (E) e alérgico $\mathrm{OVx}$ tratado com estrógeno + progesterona. Como pode ser observado, o re-desafio dos animais alérgicos OVx e daqueles tratados com estrógeno causou hiperplasia das células de Goblet em relação aos animais alérgicos, re-desafiados, mas com os ovários intactos (alérgicos Sham/OVx) (painéis B, C e D respectivamente). É interessante ressaltar que o tratamento dos animais com progesterona intensificou ainda mais a hiperplasia das células de Goblet (painel E). Em contrapartida, o tratamento com estrógeno + progesterona atenuou a hiperplasia das células de Goblet, assemelhando-se ao observado nos animais alérgicos Sham/OVx (painel F). 
Figura 13 - Fotomicrografias de cortes histológicos de pulmão corados com PAS em aumento de 40x
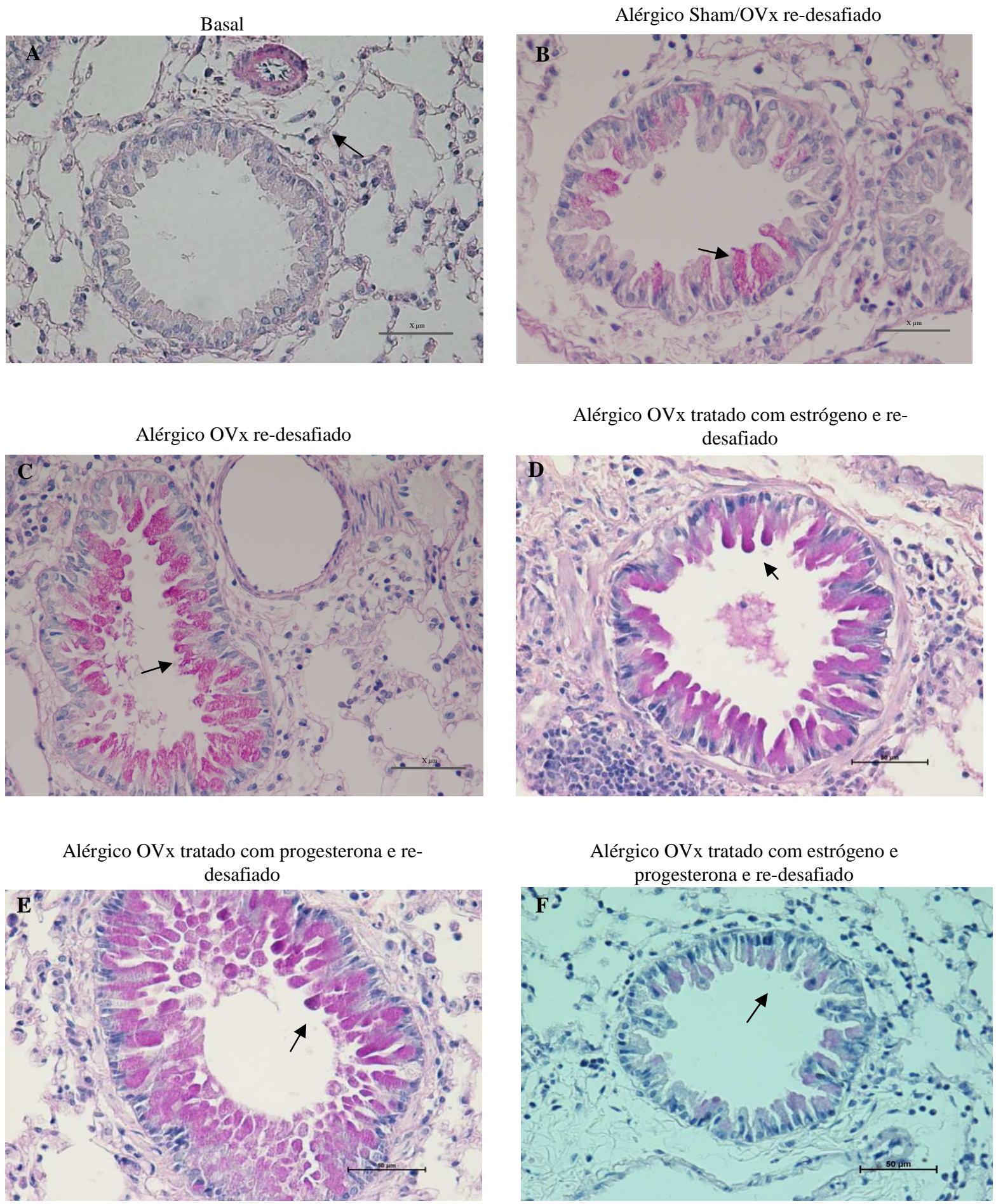

As células de Goblet do epitélio foram coradas com PAS. Painel A: basal, Painel B: Alérgico Sham/ OVx, Painel C: Alérgico OVx, Painel D: tratados com estrógeno, Painel E: tratados com progesterona, Painel F: Tratados com estrógeno e progesterona. A barra horizontal representa $40 \mu \mathrm{m}$. 
Como o observado no item 6.3, a análise histológica dos pulmões também revelou que a re-exposição dos animais alérgicos à OVA implicou em aumento do infiltrado celular quando comparado ao dos animais do grupo basal (figura 14). Este aumento foi ainda mais acentuado nos animais alérgicos que tiveram os ovários removidos ( $\mathrm{OVx}$ alérgico). É interessante ressaltar que nos animais tratados com estrógeno observamos aumento do infiltrado celular mais intenso do que o observado nos animais alérgicos OVx não tratados. Por outro lado, o tratamento dos animais com estrógeno + progesterona reduziu o infiltrado celular dos animais. 
Figura 14 - Infiltrado celular das vias aéreas em aumento de 40x.
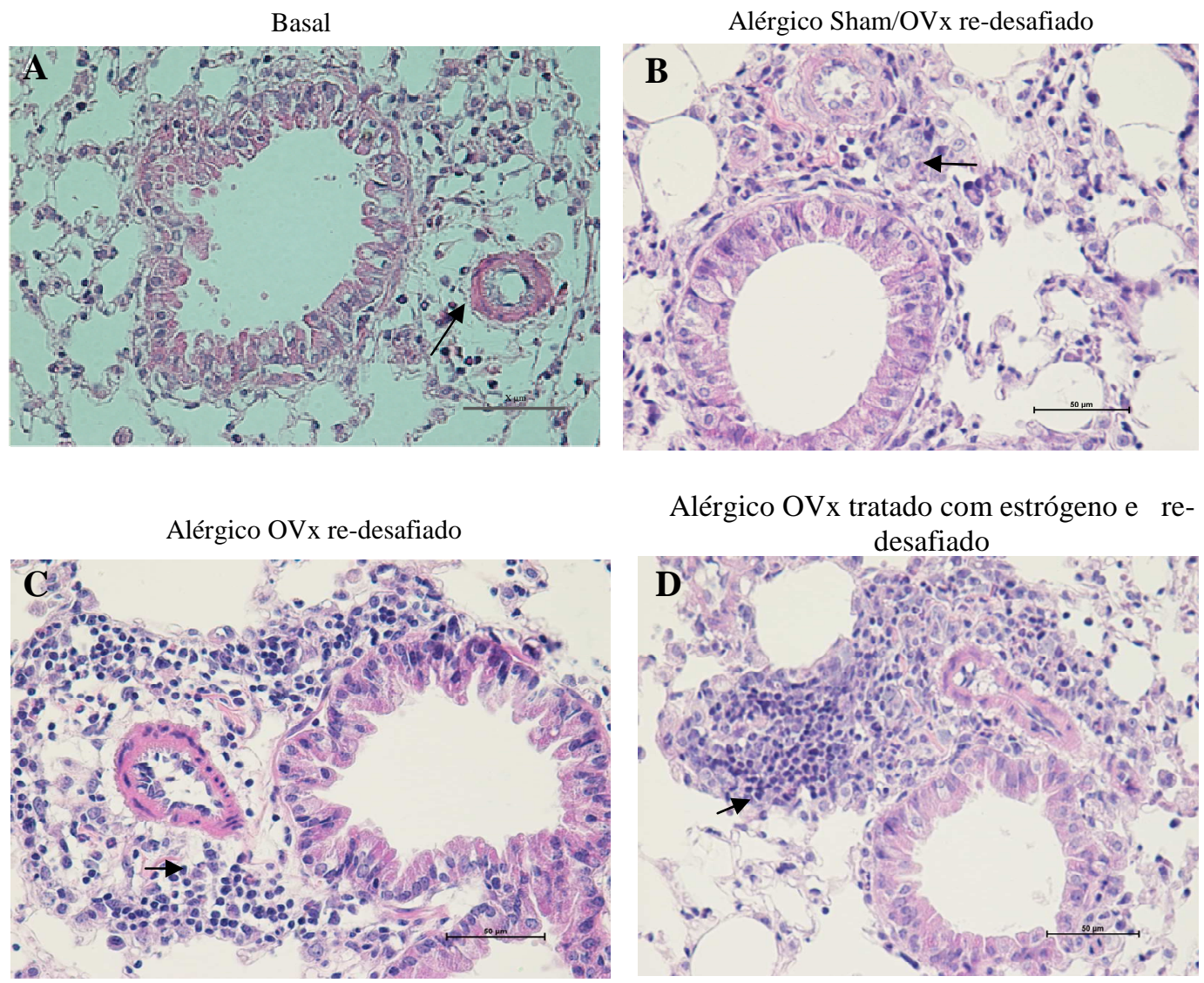

Alérgico OVx tratado com estrógeno e re-

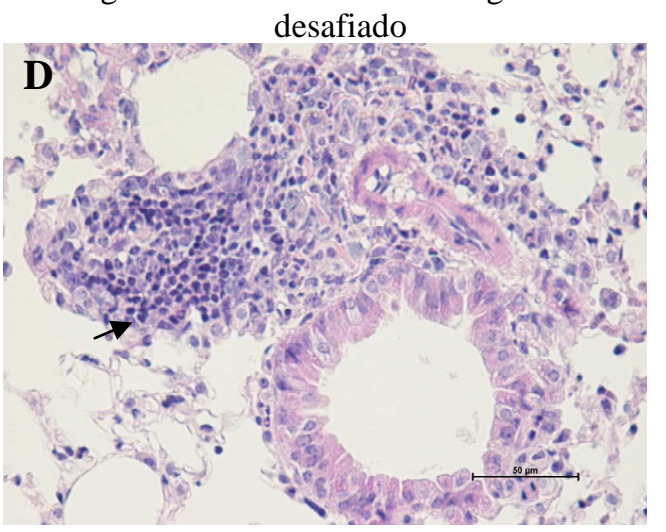

Alérgico OVx tratado com progesterona e re-desafiado

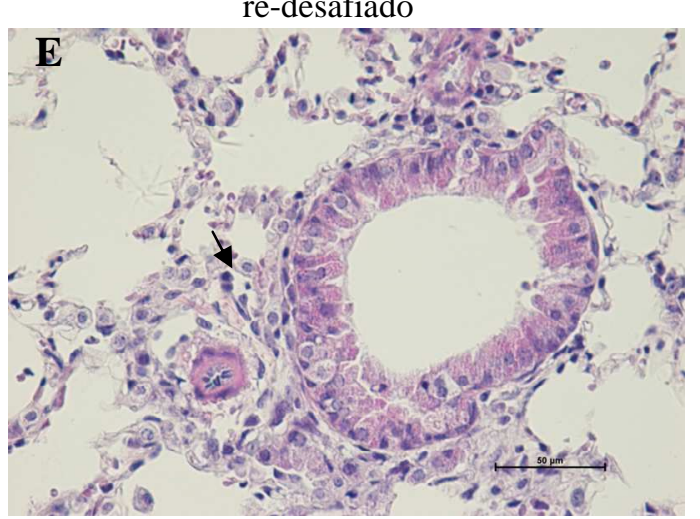

Alérgico OVx tratado com estrógeno e progesterona e re-desafiado.

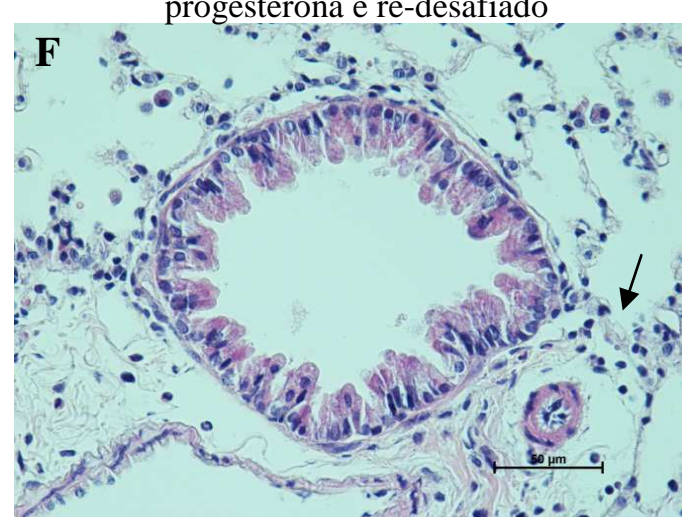

Os leucócitos do epitélio foram corados com HE. Painel A: basal, Painel B: alérgico Sham/OVx, Painel C: alérgico OVx, Painel D: tratados com estrógeno, Painel E: tratados com progesterona, Painel F: tratados com estrógeno e progesterona. A barra horizontal representa $40 \mu \mathrm{m}$. 
Tendo em vista que a remoção dos ovários e a posterior re-exposição à OVA dos animais alérgicos provocou aumento da inflamação nos pulmões, e que a deposição de colágeno pode ser uma etapa para o remodelamento das vias aéreas, o efeito da ovariectomia sobre a produção de colágeno após o re-desafio também foi investigado neste estudo. A figura 15 exibe os cortes histológicos dos pulmões dos animais do grupo basal (A), alérgico Sham/OVx (B), Alérgico OVx (C), Alérgico OVx tratado com estrógeno (D), Alérgico OVx tratado com progesterona (E) e alérgico OVx tratado com estrógeno + progesterona. Observamos que o re-desafio com OVA dos animais alérgicos Sham/OVx provocou aumento da produção de colágeno no pulmão destes animais em comparação ao observado no grupo basal. Os cortes histológicos dos pulmões dos animais alérgicos $\mathrm{OVx}$ e dos alérgicos $\mathrm{OVx}$ tratados com estrógeno não indicaram diferença na deposição de colágeno em relação ao dos animais alérgicos Sham/OVx. Por outro lado, o tratamento com progesterona, provocou aumento acentuado da produção de colágeno quando comparado aos demais grupos e o tratamento com estrógeno e progesterona reverteu esta condição. 
Figura 15 - Fotomicrografias de cortes histológicos de pulmão corados com picrossirius.

Basal

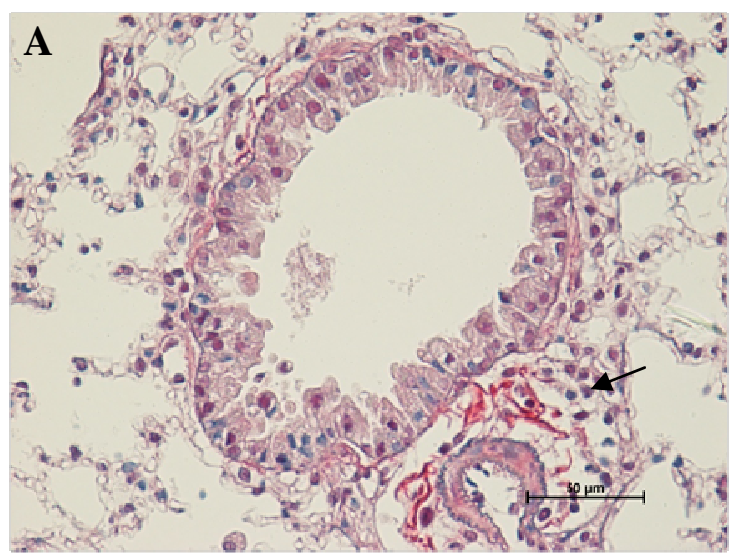

Alérgico OVx re-desafiado

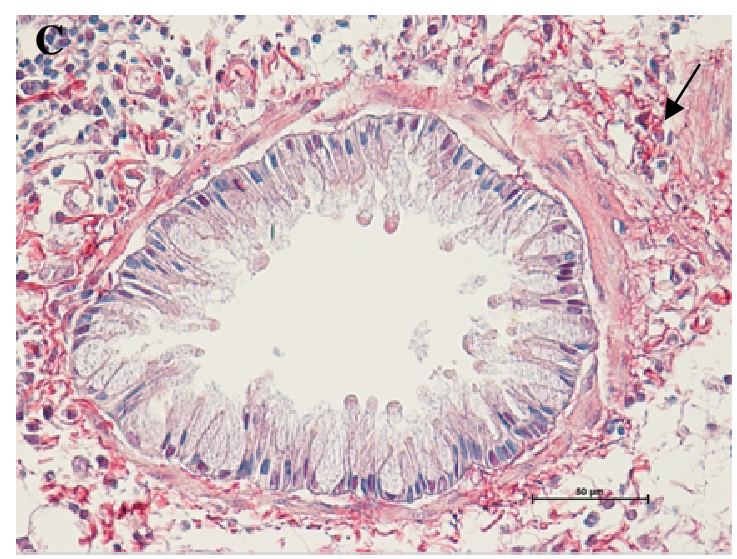

Alérgico OVx tratado com progesterona e re-desafiado

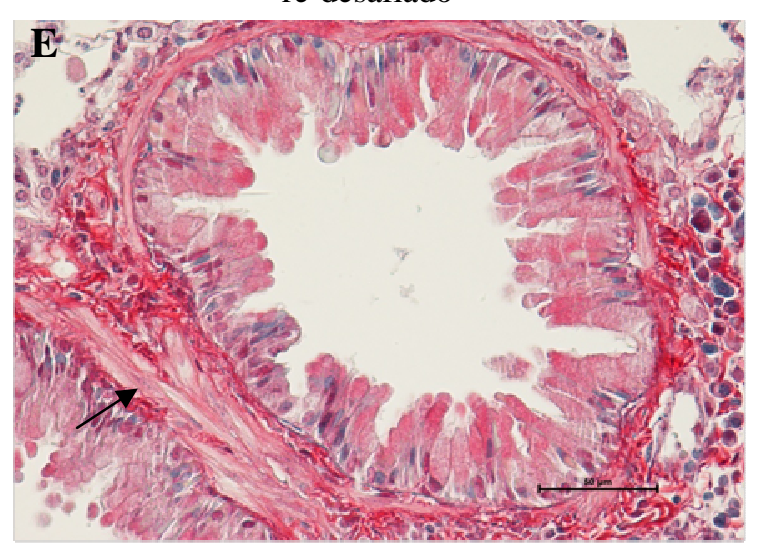

Alérgico Sham/OVx re-desafiado

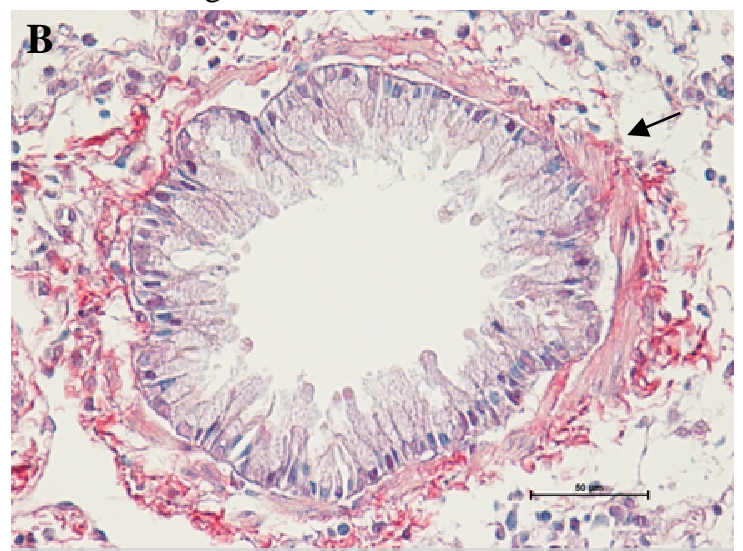

Alérgico OVx tratado com estrógeno e re-

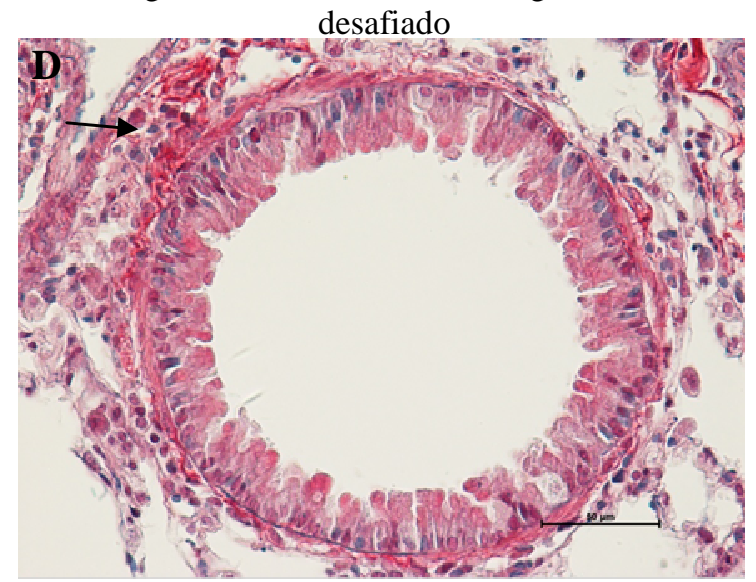

Alérgico OVx tratado com estrógeno e progesterona e re-desafiado

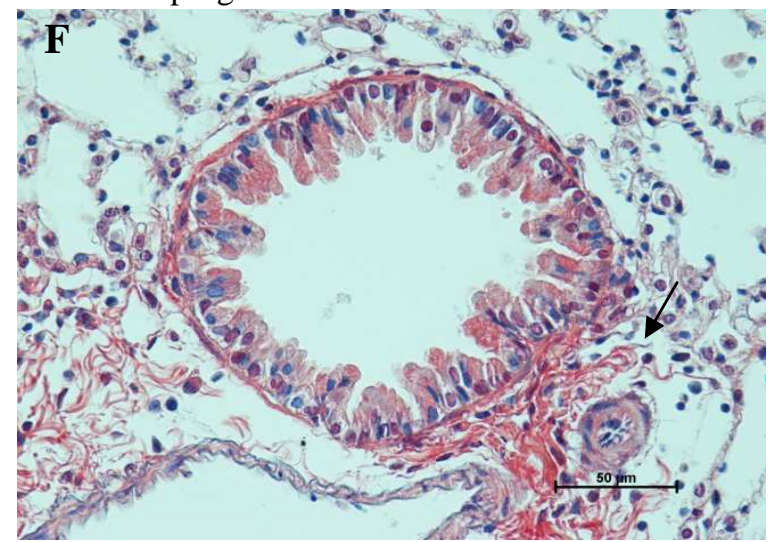

O muco foi corado com picrossirius. Painel A: basal, Painel B: alérgico Sham/OVx, Painel C: alérgico OVx, Painel D: alérgico $\mathrm{OVx}+\mathrm{E}$, Painel E: alérgico $\mathrm{OVx}+\mathrm{P}$, Painel F: alérgico OVx E+P. A barra horizontal representa $40 \mu \mathrm{m}$. 


\subsection{Efeito do re-desafio com antígeno em animais alérgicos sobre a concentração plasmática de corticosterona}

A figura 16 indica aumento da concentração plasmática de corticosterona em todos os grupos submetidos ao protocolo de inflamação pulmonar em relação aos animais basais. Os animais alérgicos OVx tiveram redução da concentração de corticosterona em relação aos alérgicos Sham/OVx. O tratamento dos animais com estrógeno não interferiu com a concentração de corticosterona quando comparada ao respectivo grupo controle alérgico OVx. Por outro lado, tanto o tratamento com progesterona quanto o tratamento com estrógeno + progesterona seguidos do re-desafio aumentou a concentração de corticosterona plasmática dos animais em relação aos animais do grupo alérgico OVx não tratados.

Figura 16 - Efeito da ovariectomia $(\mathrm{OVx})$ sobre a concentração de corticosterona plasmática.

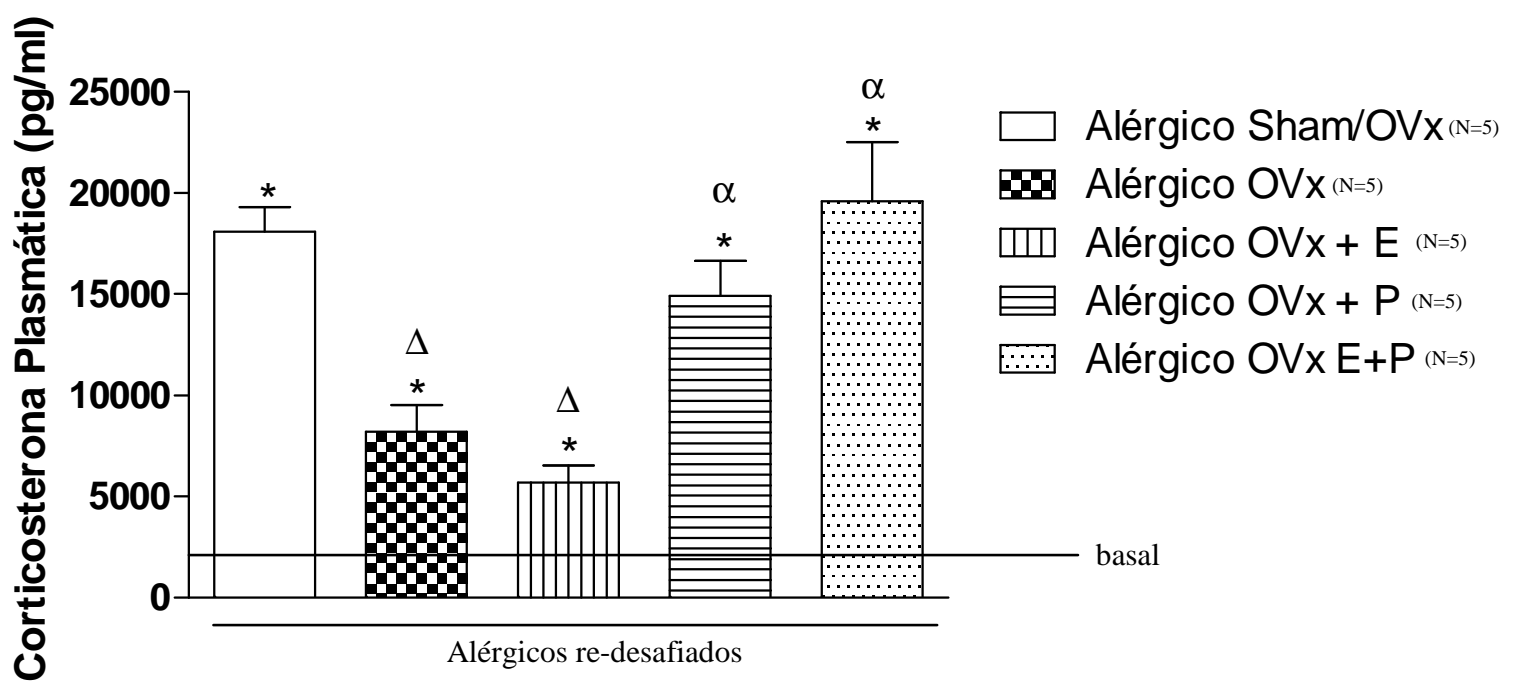

Os grupos consistiram de animais não manipulados (basal), animais sensibilizados, desafiados com OVA posteriormente ovariectomizados e novamente desafiados com OVA, animais sensibilizados, desafiados com OVA posteriormente ovariectomizados, tratados com estrógeno e/ou progesterona e novamente desafiados com OVA e como controle foram utilizadas camundongos fêmeas sensibilizadas e desafiadas com OVA e posteriormente submetidas à falsa cirurgia de remoção dos ovários (Sham) e novamente desafiadas com OVA. Decorridos $24 \mathrm{~h}$ do último desafio os animais foram eutanasiados e o lavado femural realizado. Os dados representam a média \pm EPM de 5 animais. ${ }^{\Delta} \mathrm{p}<0,05$ em relação ao grupo alérgico Sham/OVx; ${ }^{\alpha} \mathrm{p}<0,05$ em relação ao grupo alérgico $\mathrm{OVx}$. 


\subsection{Efeito do re-desafio com antígeno em animais alérgicos sobre a reatividade traqueal in vitro}

A Figura 17 mostra aumento significante da reatividade de anéis de traquéia dos animais alérgicos re-desafiados dos grupos alérgicos Sham/OVx e OVx frente à metacolina em relação ao grupo basal. É interessante ressaltar que sob o efeito das concentrações iniciais da construção da curva dose-resposta à metacolina, os anéis de traquéia dos animais alérgicos OVx estão menos reativos que os dos animais alérgicos Sham/OVx. À medida que as concentrações mais elevadas de metacolina são adicionadas, a reatividade dos anéis de traquéia dos animais alérgicos OVx aumenta, equiparando-se ao observado nos animais alérgicos Sham/OVx. Desta forma, o re-desafio posterior à ovariectomia não altera a reatividade traqueal in vitro em relação ao observado nos animais alérgicos Sham/OVx. Por outro lado, o tratamento dos animais alérgicos $\mathrm{OVx}$ com estrógeno ou com progesterona preveniu o aumento da reatividade da traquéia destes animais, que apresentaram aumento da reatividade traqueal apenas em relação aos animais basais. 
Figura 17 - Efeito da ovariectomia sobre a reatividade traqueal in vitro 24 h após a última broncoprovocação.

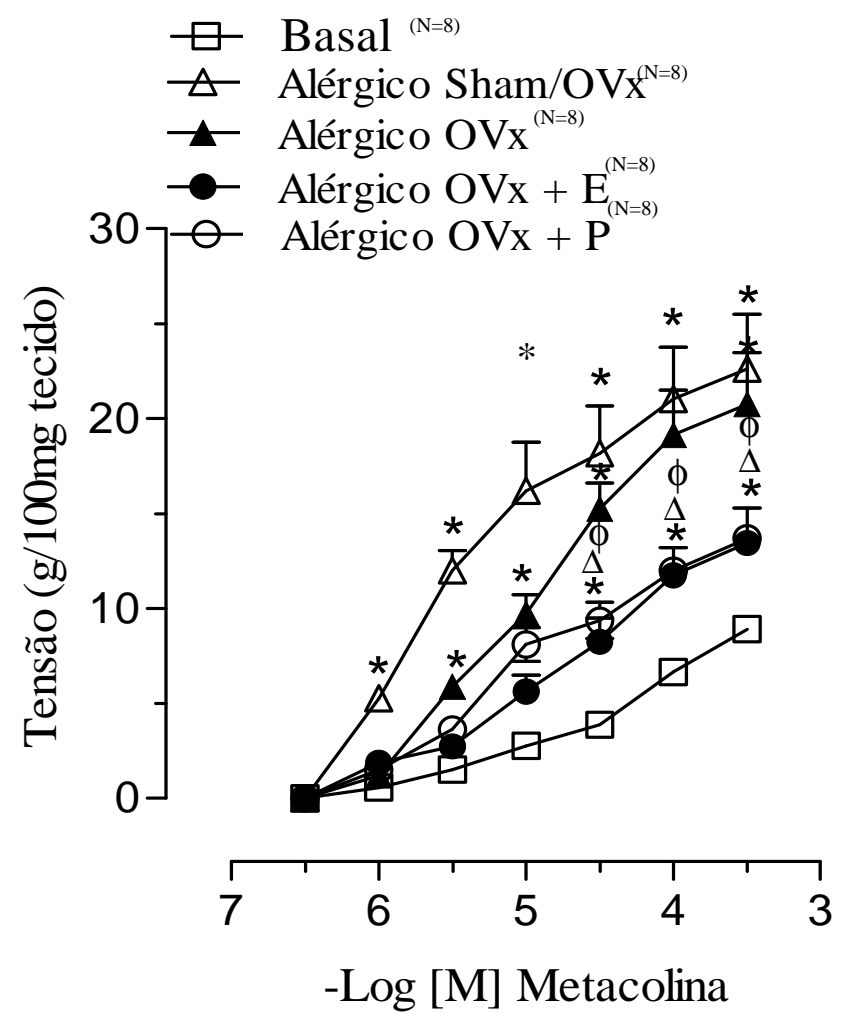

Os grupos consistiram de animais não manipulados (basal), animais sensibilizados, desafiados com OVA posteriormente ovariectomizados e novamente desafiados com OVA (alérgico OVx), animais sensibilizados, desafiados com OVA posteriormente ovariectomizados, tratados com estrógeno ou progesterona e novamente desafiados com OVA $(\mathrm{OV} x+\mathrm{E}$ e $\mathrm{OVx}+\mathrm{P}$ respectivamente) e como controle foram utilizadas camundongos fêmeas sensibilizadas e desafiadas com OVA e posteriormente submetidos à falsa cirurgia de remoção dos ovários e novamente desafiadas com OVA (alérgico Sham/OVx). Decorridos $24 \mathrm{~h}$ do último desafio os animais foram submetidos à eutanásia e um segmento da traquéia foi obtido para avaliação da reatividade. Os dados representam a média \pm EPM de 8 animais. ${ }^{*} \mathrm{p}<0,05 \mathrm{em}$ relação ao grupo basal; ${ }^{\Delta} \mathrm{p}<0,05 \mathrm{em}$ relação ao grupo Sham/OVx; ${ }^{\phi} \mathrm{p}<0,05$ em relação ao grupo OVx. 


\subsection{Efeito do re-desafio com antígeno em animais alérgicos sobre a mecânica respiratória}

O painel (A) da figura 18 representa a resistência do sistema respiratório. Primeiramente, observamos que a inalação dos animais com PBS não alterou a resistência das vias aéreas em relação a observada em condições basais. O re-desafio dos animais alérgicos Sham/OVx acarretou aumento da resistência das vias aéreas após inalação de MCh (50 $\mathrm{mg} / \mathrm{ml}$ ) e a re-exposição ao antígeno dos animais alérgicos OVx causou aumento ainda maior da resistência das vias aéreas também após inalação de MCh $(50 \mathrm{mg} / \mathrm{ml})$. Por outro lado, o redesafio seguido do tratamento dos animais alérgicos OVx com estrógeno, progesterona ou estrógeno + progesterona atenuou o aumento da resistência do sistema respiratório destes animais, mesmo após inalação de $\mathrm{MCh}(50 \mathrm{mg} / \mathrm{ml})$. De interesse, é que após os tratamentos, os animais passaram a apresentar resistência similar à dos animais alérgicos Sham/OVx.

Um perfil similar ao da resistência das vias aéreas pode ser observado em relação aos dados da elastância das vias aéreas (Painel B, Figura 18). Nesse sentido, observamos novamente que a re-exposição dos animais alérgicos $\mathrm{OVx}$ ao antígeno provocou aumento significante da resposta máxima após a nebulização da concentração de $50 \mathrm{mg} / \mathrm{ml}$ de MCh em relação ao aumento verificado nos animais alérgicos Sham/OVx. Uma vez mais, o tratamento dos animais alérgicos OVx tanto com estrógeno como com progesterona ou com ambos os hormônios foi capaz de reduzir a elastância, levando a valores próximos ao observado nos animais alérgicos Sham/OVx. 
Figura 18 - Efeito da ovariectomia sobre a (A) resistência pulmonar e (B) elastância pulmonar in vivo $24 \mathrm{~h}$ após a última broncoprovocação
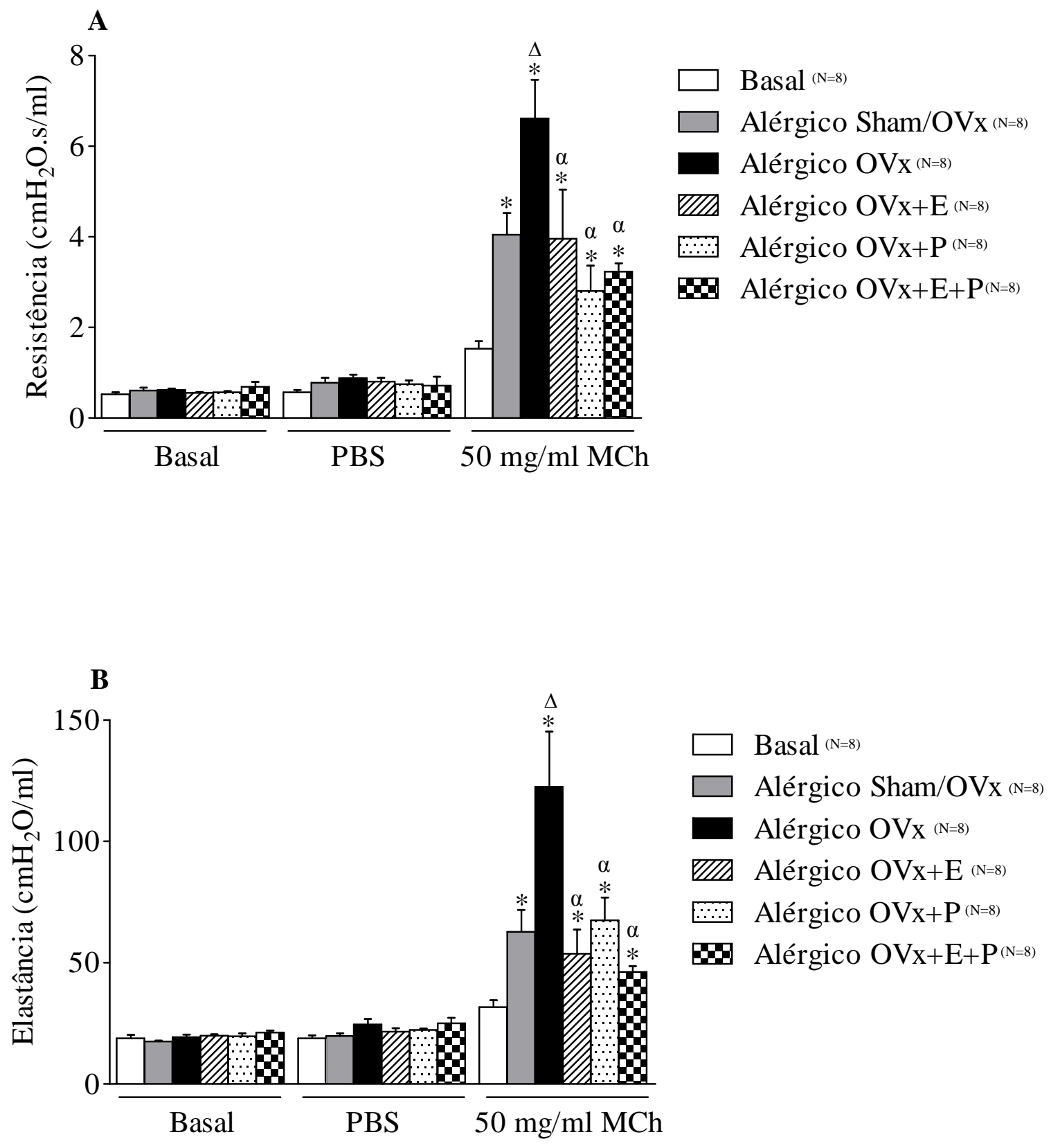

Os grupos consistiram de animais não manipulados (basal), animais sensibilizados, desafiados com OVA posteriormente ovariectomizados e novamente desafiados com OVA (alérgico OVx), animais sensibilizados, desafiados com OVA posteriormente ovariectomizados, tratados com estrógeno ou progesterona ou ambos e novamente desafiados com OVA $(\mathrm{OVx}+\mathrm{E} ; \mathrm{OVx}+\mathrm{P}$ e $\mathrm{OVx} \mathrm{E}+\mathrm{P}$ respectivamente) e como controle foram utilizadas camundongos fêmeas sensibilizadas e desafiadas com OVA e posteriormente submetidos à falsa cirurgia de remoção dos ovários e novamente desafiadas com OVA (alérgico Sham/OVx). Decorridos 24 h do último desafio, os animais foram submetidos à avaliação da mecânica respiratória no flexiVent. Os dados representam a média \pm EPM de 8 animais. ${ }^{*} \mathrm{p}<0,05$ em relação ao grupo basal ${ }^{\Delta} \mathrm{p}<0,05 \mathrm{em}$ relação ao grupo Sham/OVx; ${ }^{\alpha} \mathrm{p}<0,05$ em relação ao grupo $\mathrm{OVx}$ alérgico. 


\subsection{Efeito do re-desafio com antígeno em animais alérgicos sobre a geração de mediadores inflamatórios em explante pulmonar}

a) IL-4: A figura 19 indica que todos os grupos experimentais tiveram aumento de IL-4 no explante pulmonar quando comparados à liberação de IL-4 quantificada no explante dos animais basais. Ademais, os animais alérgicos, ovariectomizados e expostos ao re-desafio (grupo alérgico OVx) apresentaram aumento significativo da geração de IL-4 no explante pulmonar em relação ao seu respectivo grupo controle (alérgico Sham/OVx). O tratamento dos animais OVx com estrógeno ou com progesterona não interferiu com o observado aumento da concentração de IL-4 no explante destes animais. Por outro lado, o tratamento com estrógeno + progesterona reduziu a concentração de IL-4 em relação ao verificado nos animais alérgicos $\mathrm{OVx}$.

Figura 19 - Níveis de IL-4 em explante pulmonar

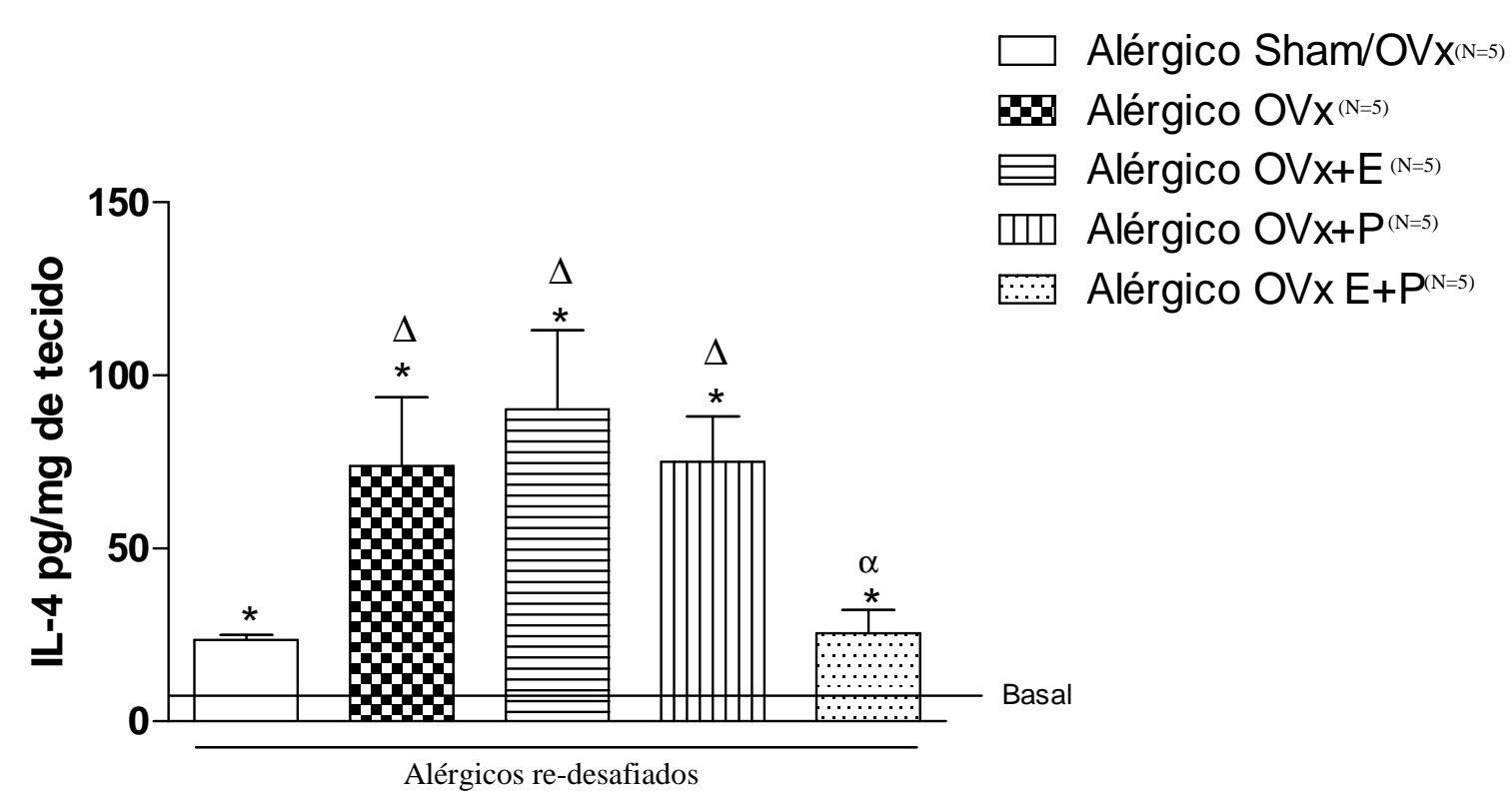

Os grupos consistiram de animais não manipulados (basal), animais sensibilizados, desafiados com OVA posteriormente ovariectomizados e novamente desafiados com OVA (OVx alégico), animais sensibilizados, desafiados com OVA posteriormente ovariectomizados, tratados com estrógeno ou progesterona e novamente desafiados com OVA $(\mathrm{OVx}+\mathrm{E}$ e $\mathrm{OVx}+\mathrm{P}$ respectivamente) e como controle foram utilizadas camundongos fêmeas sensibilizadas e desafiadas com OVA e posteriormente submetidos à falsa cirurgia de remoção dos ovários e novamente desafiadas com OVA (Sham/OVx). Os dados representam a média \pm EPM de 5 animais. ${ }^{*} \mathrm{p}<0,05$ em relação ao grupo basal, ${ }^{\Delta} \mathrm{p}<0,05$ em relação ao grupo alérgico Sham/OVx ${ }^{\alpha} \mathrm{p}<0,05$ em relação ao grupo alérgico $\mathrm{OVx}$. 
b) IL-5: Com relação à IL-5, mais uma vez observamos que todos os grupos experimentais tiveram aumento da geração desta citocina no explante pulmonar quando comparados ao quantificado no explante dos animais basais. Os dados apresentados na figura 20 apontam ainda que os animais alérgicos OVx re-desafiados tiveram aumento da geração de IL-5 no explante de pulmão em relação ao observado nos do grupo alérgico Sham/OVx. O tratamento dos animais alérgicos OVx com estrógeno ou com progesterona seguido da re-exposição ao antígeno não provocou alteração na elevada liberação de IL-5. Todavia o tratamento dos animais com estrógeno + progesterona, por sua vez, apesar de também não ter alterado a liberação de IL-5 em relação aos alérgicos OVx, verificamos uma tendência de redução deste mediador nestes animais.

Figura 20 - Níveis de IL-5 em explante pulmonar

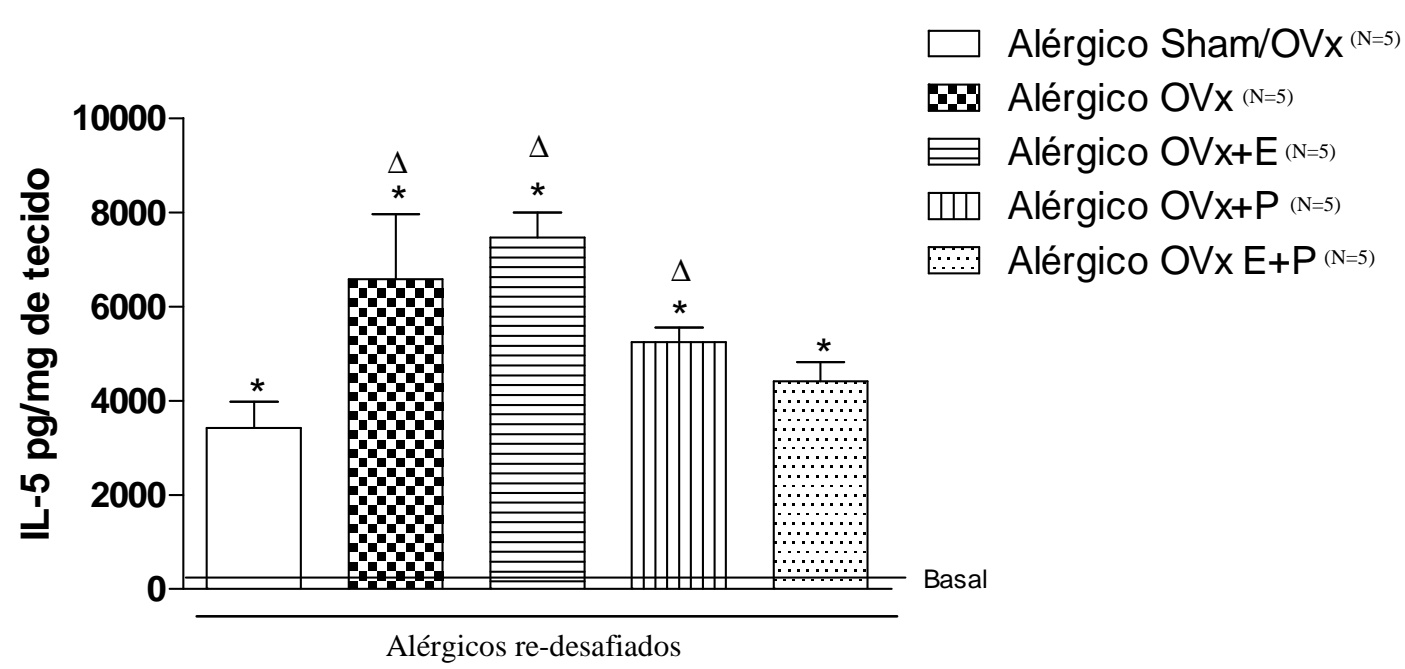

Os grupos consistiram de animais não manipulados (basal), animais sensibilizados, desafiados com OVA posteriormente ovariectomizados e novamente desafiados com OVA (OVx alégico), animais sensibilizados, desafiados com OVA posteriormente ovariectomizados, tratados com estrógeno ou progesterona e novamente desafiados com OVA $(\mathrm{OVx}+\mathrm{E}$ e $\mathrm{OVx}+\mathrm{P}$ respectivamente) e como controle foram utilizadas camundongos fêmeas sensibilizadas e desafiadas com OVA e posteriormente submetidos à falsa cirurgia de remoção dos ovários e novamente desafiadas com OVA (Sham/OVx). Os dados representam a média \pm EPM de 5 animais. ${ }^{*} \mathrm{p}<0,05$ em relação ao grupo basal $,{ }^{\Delta} \mathrm{p}<0,05$ em relação ao grupo alérgico Sham/OVx. 


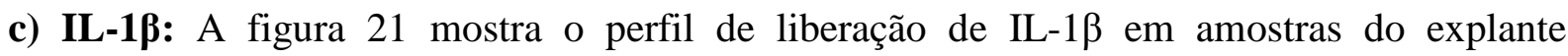
pulmonar. Podemos observar que todos os animais alérgicos e re-desafiados tiveram aumento da liberação de IL-1 $\beta$ no explante pulmonar em relação à liberação desta citocina no explante dos animais basais. Os animais alérgicos OVx tiveram aumento da liberação de IL-1 $\beta$ quando comparados ao observado no explante dos animais alérgicos Sham/OVx. A liberação de IL-1 $\beta$ no sobrenadante do explante dos animais tratados com estrógeno, progesterona ou ambos os hormônios não diferiu do observado no respectivo grupo controle alérgico OVx. Apesar do mencionado, nota-se uma tendência de redução da geração de IL-1 $\beta$ após o tratamento conjunto de estrógeno + progesterona.

Figura 21 - Níveis de IL-1 $\beta$ em explante pulmonar.

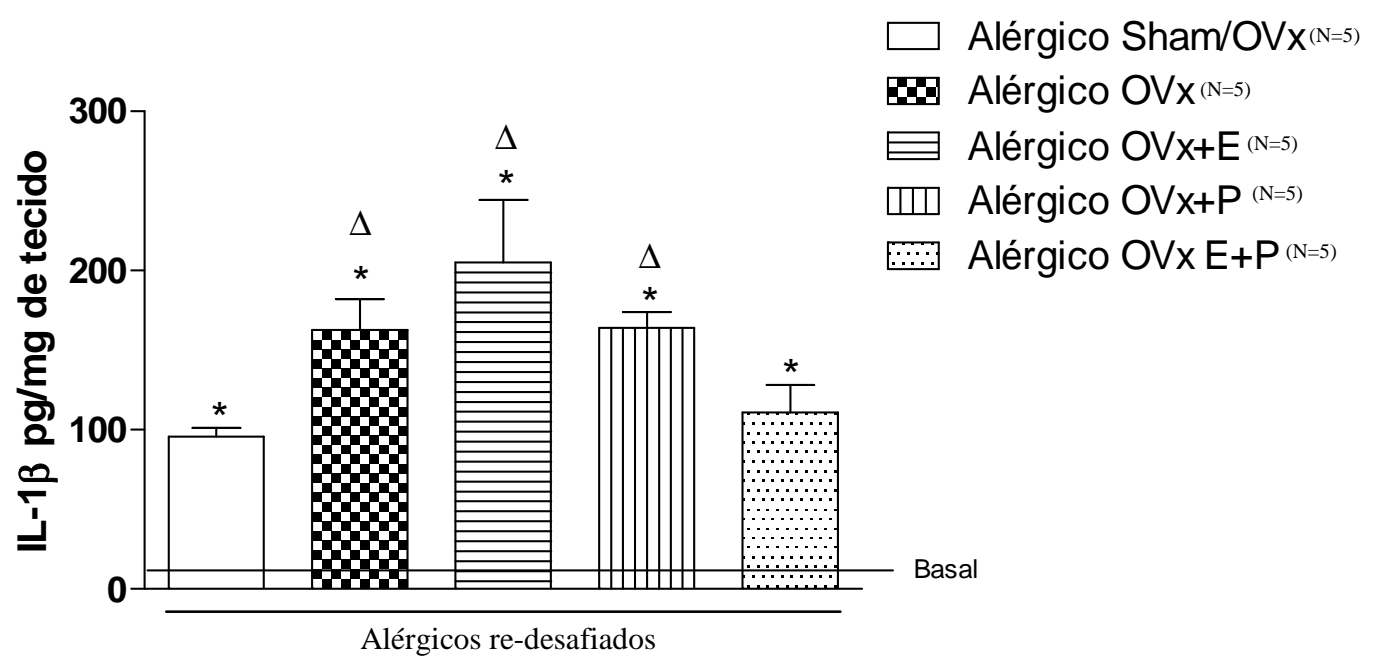

Os grupos consistiram de animais não manipulados (basal), animais sensibilizados, desafiados com OVA posteriormente ovariectomizados e novamente desafiados com OVA (OVx alégico), animais sensibilizados, desafiados com OVA posteriormente ovariectomizados, tratados com estrógeno ou progesterona e novamente desafiados com OVA $(\mathrm{OVx}+\mathrm{E}$ e $\mathrm{OVx}+\mathrm{P}$ respectivamente) e como controle foram utilizadas camundongos fêmeas sensibilizadas e desafiadas com OVA e posteriormente submetidos à falsa cirurgia de remoção dos ovários e novamente desafiadas com OVA (Sham/OVx). Os dados representam a média \pm EPM de 5 animais. $* \mathrm{p}<0,05$ em relação ao grupo basa ${ }^{\Delta} \mathrm{p}<0,05$ em relação ao grupo alérgico Sham/OVx, ${ }^{\alpha} \mathrm{p}<0,05$ em relação ao grupo alérgico $\mathrm{OVx}$ 
d) IL-13: Verificamos aumento da geração de IL-13 no explante de pulmão de todos os animais alérgicos e re-desafiados em comparação ao quantificado no explante dos animais basais (Figura 22). Os resultados obtidos também indicaram aumento significante de IL-13 nas amostras de explante de pulmão dos animais alérgicos OVx em relação ao quantificado nas amostras dos animais alérgicos Sham/OVx. A geração de IL-13 nas amostras de explante pulmonar dos animais tratados com estrógeno ou com progesterona não tiveram diferença em relação ao observado nas amostras do grupo controle alérgico OVx. Por outro lado, o tratamento dos animais com estrógeno + progesterona reduziu a liberação de IL-13 no explante pulmonar em relação ao observado no dos animais alérgicos $\mathrm{OVx}$.

Figura 22 - Níveis de IL-13 em explante pulmonar.

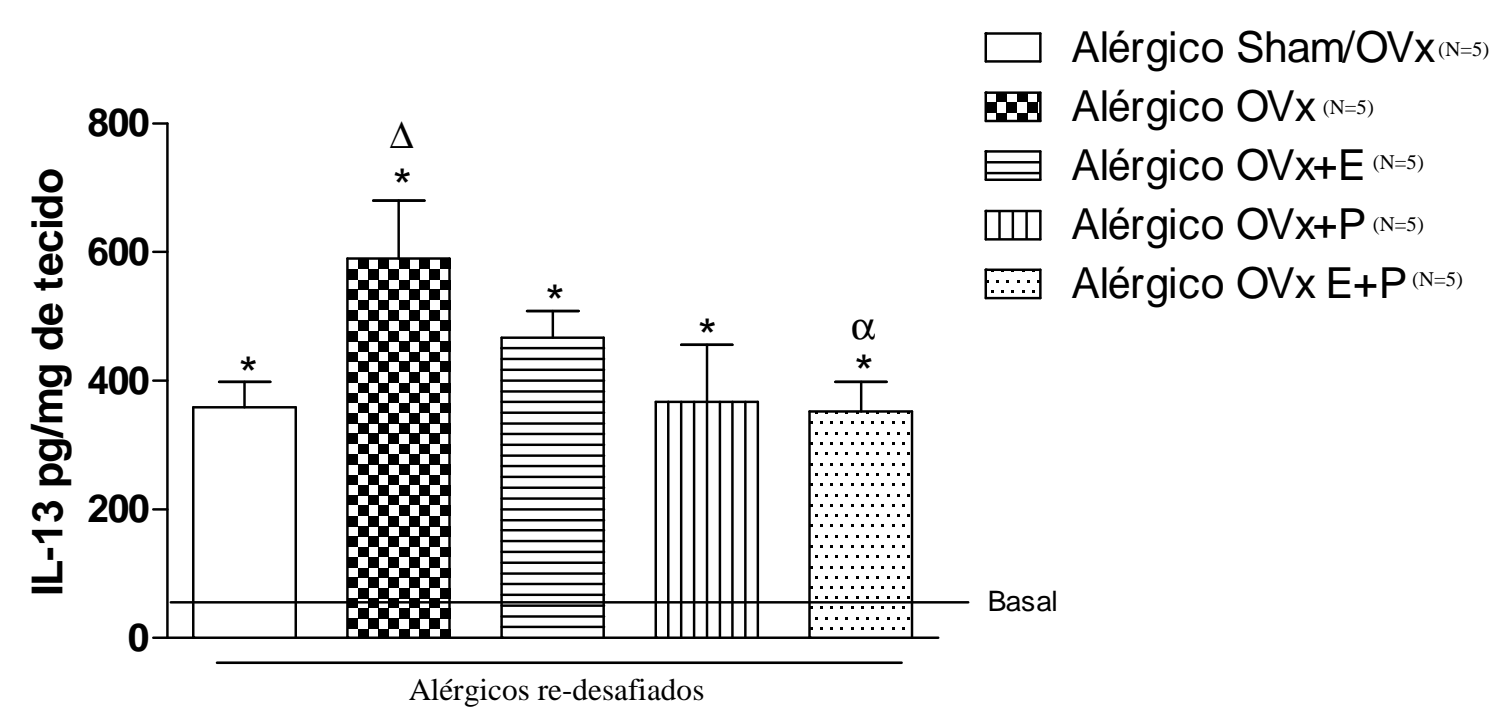

Os grupos consistiram de animais não manipulados (basal), animais sensibilizados, desafiados com OVA posteriormente ovariectomizados e novamente desafiados com OVA (OVx alégico), animais sensibilizados, desafiados com OVA posteriormente ovariectomizados, tratados com estrógeno ou progesterona e novamente desafiados com OVA $(\mathrm{OVx}+\mathrm{E}$ e $\mathrm{OVx}+\mathrm{P}$ respectivamente) e como controle foram utilizadas camundongos fêmeas sensibilizadas e desafiadas com OVA e posteriormente submetidos à falsa cirurgia de remoção dos ovários e novamente desafiadas com OVA (Sham/OVx). Os dados representam a média \pm EPM de 5 animais. ${ }^{*} \mathrm{p}<0,05$ em relação ao grupo basal, ${ }^{\Delta} \mathrm{p}<0,05$ em relação ao grupo alérgico Sham/OVx, ${ }^{\alpha} \mathrm{p}<0,05$ em relação ao grupo alérgico $\mathrm{OVx}$. 
e) TNF- $\alpha$ : A análise dos dados representados pela figura 23 revelou que a re-exposição ao antígeno dos animais alérgicos causou aumento significante da liberação de TNF- $\alpha$ no explante de pulmão dos animais em comparação ao observado nos basais. Os animais alérgicos OVx tiveram aumento da liberação de TNF- $\alpha$ no explante pulmonar em relação ao verificado nos animais alérgicos Sham/OVx. Por outro lado, o tratamento destes animais com estrógeno, progesterona ou ambos os hormônios causou redução da liberação desta citocina.

Figura 23 - Níveis de TNF- $\alpha$ em explante pulmonar.

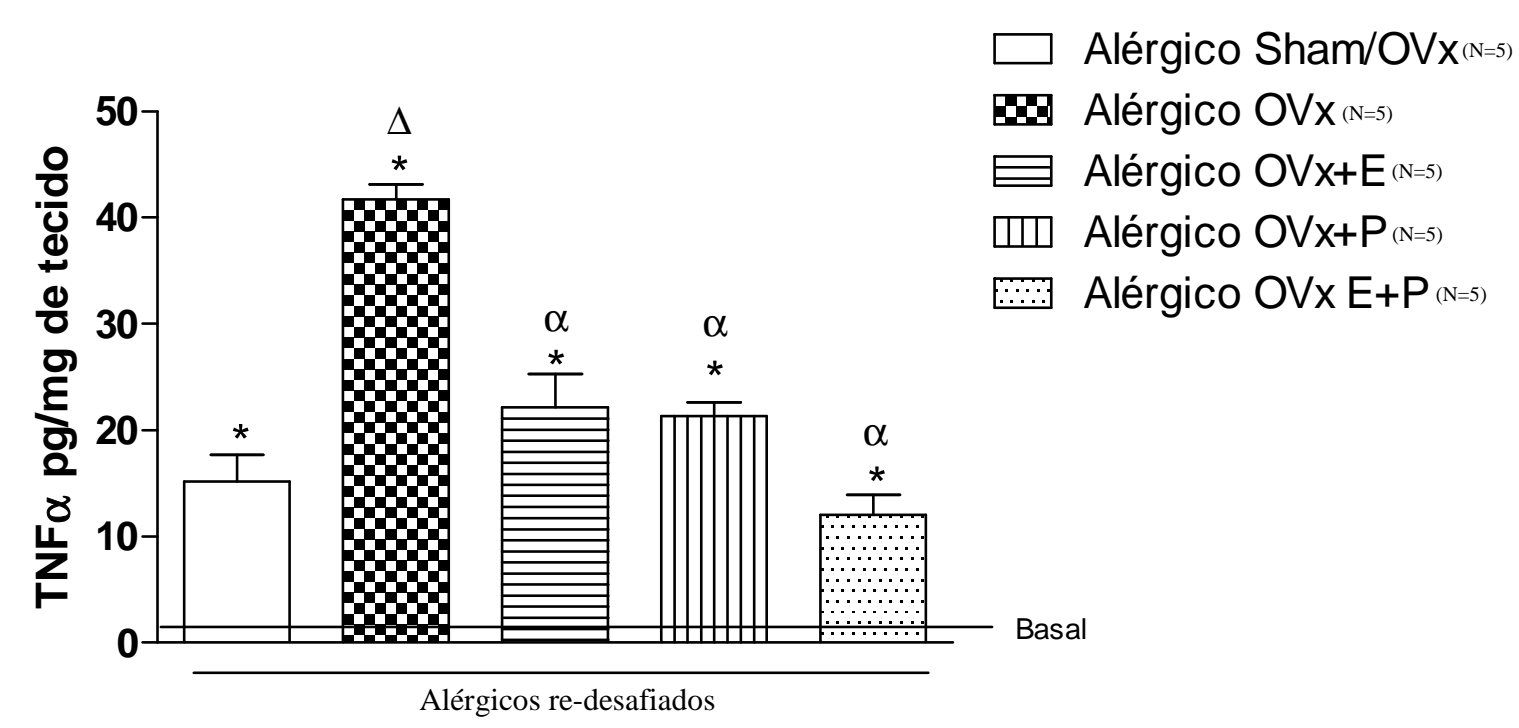

Os grupos consistiram de animais não manipulados (basal), animais sensibilizados, desafiados com OVA posteriormente ovariectomizados e novamente desafiados com OVA (OVx alégico), animais sensibilizados, desafiados com OVA posteriormente ovariectomizados, tratados com estrógeno ou progesterona e novamente desafiados com OVA $(\mathrm{OV} x+\mathrm{E}$ e $\mathrm{OVx}+\mathrm{P}$ respectivamente) e como controle foram utilizadas camundongos fêmeas sensibilizadas e desafiadas com OVA e posteriormente submetidos à falsa cirurgia de remoção dos ovários e novamente desafiadas com OVA (Sham/OVx). Os dados representam a média \pm EPM de 5 animais. ${ }^{*} \mathrm{p}<0,05$ em relação ao grupo basal, ${ }^{\Delta} \mathrm{p}<0,05$ em relação ao grupo alérgico Sham/OVx, ${ }^{\alpha} \mathrm{p}<0,05$ em relação ao grupo alérgico $\mathrm{OVx}$. 
f) IL-10: A figura 24 também indica aumento de IL-10 no explante de pulmão dos animais alérgicos re-desafiados quando comparados ao observado no explante do grupo basal. A figura revela ainda que o re-desafio dos animais alérgicos OVx não alterou a geração de IL-10 no explante pulmonar quando comparada ao detectado no explante dos animais do grupo alérgico Sham/OVx re-desafiado. Por outro lado, o tratamento dos animais alérgicos OVx com estrógeno causou aumento significante de IL-10, o qual foi potencializado pelo tratamento dos animais com progesterona. Já o tratamento conjunto com estrógeno + progesterona, causou redução significante da liberação de IL-10 no explante de pulmão dos animais.

Figura 24 - Níveis de IL-10 em explante pulmonar.

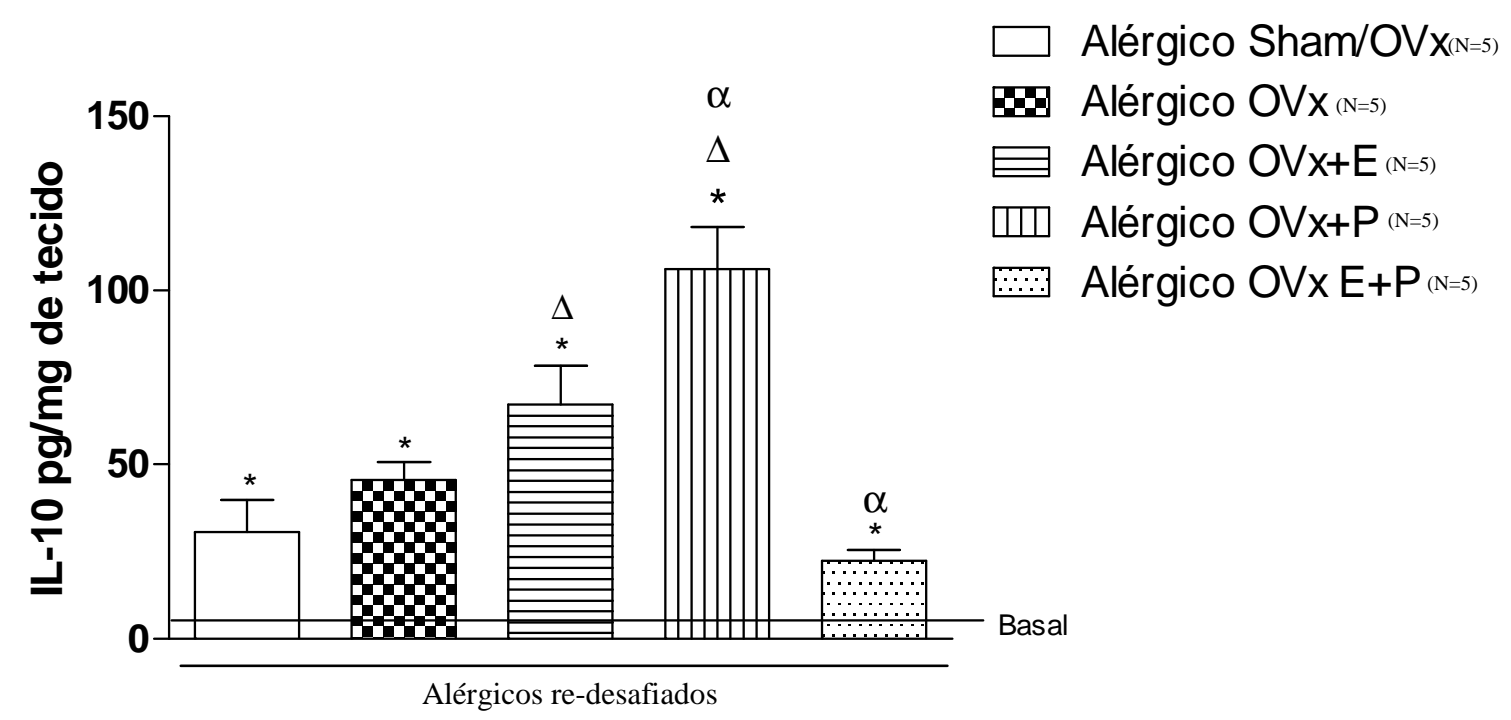

Os grupos consistiram de animais não manipulados (basal), animais sensibilizados, desafiados com OVA posteriormente ovariectomizados e novamente desafiados com OVA (OVx alégico), animais sensibilizados, desafiados com OVA posteriormente ovariectomizados, tratados com estrógeno ou progesterona e novamente desafiados com OVA $(\mathrm{OV} x+\mathrm{E}$ e $\mathrm{OVx}+\mathrm{P}$ respectivamente) e como controle foram utilizadas camundongos fêmeas sensibilizadas e desafiadas com OVA e posteriormente submetidos à falsa cirurgia de remoção dos ovários e novamente desafiadas com OVA (Sham/OVx). Os dados representam a média \pm EPM de 5 animais. ${ }^{*} \mathrm{p}<0,05$ em relação ao grupo basal, ${ }^{\Delta} \mathrm{p}<0,05$ em relação ao grupo alérgico Sham/OVx, ${ }^{\alpha} \mathrm{p}<0,05$ em relação ao grupo alérgico $\mathrm{OVx}$. 


\subsection{Efeito do re-desafio com antígeno em animais alérgicos sobre a geração de $\mathrm{NO}_{2}$ em cultura de células explante pulmonar}

Podemos observar na figura de 25 que o re-desafio dos animais alérgicos OVx não alterou a geração de $\mathrm{NO}_{2}$ em relação aos animais alérgicos Sham/OVx. O tratamento dos animais com estrógeno ou com progesterona aumentou de forma significativa a geração de $\mathrm{NO}_{2}$ no explante pulmonar destes animais. Todavia, o tratamento dos animais alérgicos com estrógeno + progesterona, manteve a concentração de $\mathrm{NO}_{2}$ a valores similares aos observados nos explantes de pulmão dos animais dos grupos alérgico OVx e alérgico Sham/OVx .

Figura 25 - Níveis de $\mathrm{NO}_{2}$ em explante pulmonar.

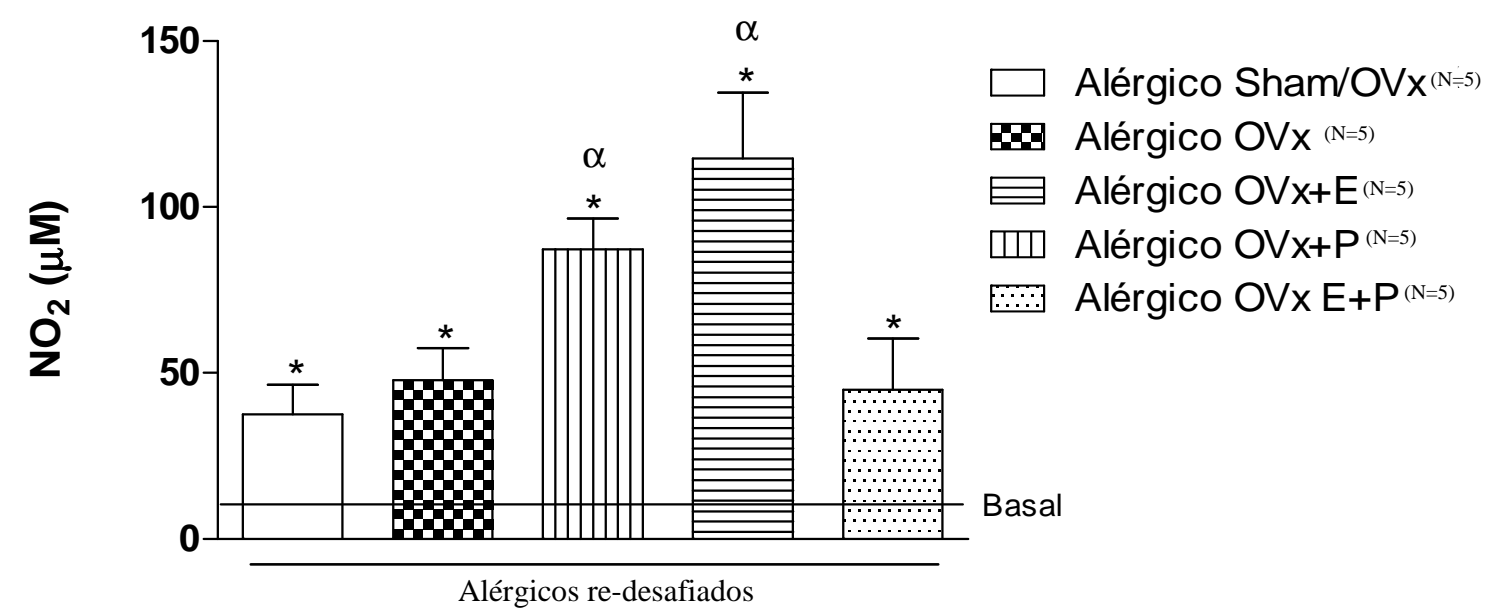

Os grupos consistiram de animais não manipulados (basal), animais sensibilizados, desafiados com OVA posteriormente ovariectomizados e novamente desafiados com OVA (OVx alégico), animais sensibilizados, desafiados com OVA posteriormente ovariectomizados, tratados com estrógeno ou progesterona ou ambos e novamente desafiados com OVA $(\mathrm{OV} x+\mathrm{E} ; \mathrm{OVx}+\mathrm{P}$ e $\mathrm{OVx} \mathrm{E}+\mathrm{P}$ respectivamente $)$ e como controle foram utilizadas camundongos fêmeas sensibilizadas e desafiadas com OVA e posteriormente submetidos à falsa cirurgia de remoção dos ovários e novamente desafiadas com OVA (Sham/OVx). Os dados representam a média \pm EPM de 5 animais. ${ }^{\Delta} \mathrm{p}<0,05$ em relação ao grupo alérgico Sham/OVx ${ }^{\alpha} \mathrm{p}<0,05$ em relação ao grupo alérgico $\mathrm{OVx}$. 


\section{DISCUSSÃO}

O desencadeamento e manutenção da asma estão sob influência do sistema imunológico onde a sensibilização do indivíduo ao antígeno, seu processamento e a conseqüente geração de anticorpos norteiam o desenvolvimento da resposta alérgica (GALLI et al., 2008). A inflamação pulmonar alérgica é caracterizada por episódios reversíveis do aumento do recrutamento de células inflamatórias para os pulmões, pelo aumento da liberação de citocinas inflamatórias, lesão epitelial e obstrução do fluxo aéreo. Sabe-se que a oscilação dos hormônios sexuais femininos durante o ciclo sexual e sua redução na pós-menopausa são fatores de contribuição para a piora dos sintomas da asma (BORNELOV, 2013; GINA, 2013).

No presente estudo apresentamos dados acerca da potencial participação dos hormônios sexuais femininos sobre o curso da inflamação pulmonar alérgica já instalada. A asma é uma doença multifatorial, isto é, pode ser determinada por fatores genéticos, ambientais e ocupacionais, caracterizada também por múltiplas manifestações fenotípicas e endotípicas (SIBBALDI et al., 1992; SKIEPKO et al., 2009; WENZEL, 2012).

Os diferentes fenótipos da asma estão associados, por exemplo, às variações da manifestação da inflamação das vias aéreas, aos sintomas, à severidade e a resposta ao tratamento (AGACHE, 2013).

Resumidamente, o termo asma endotípica baseia-se no conceito de que a asma se apresenta por meio de distintos mecanismos funcionais ou fisiológicos, levando a diversos subtipos da doença que apresenta como final comum a obstrução do fluxo respiratório. (AGACHE, 2013; GIBSON et al., 2001; LOTVALL, 2011).

Como dito anteriormente, estudos mostram que mulheres asmáticas apresentam piora dos sintomas nos períodos da pré e pós menopausa e é bem estabelecido na literatura que a flutuação dos hormônios sexuais femininos durante o ciclo sexual e a terapia de reposição hormonal em mulheres na pós-menopausa podem concorrer para a piora dos sintomas da asma. Sabe-se que os hormônios sexuais femininos exercem efeitos regulatórios no curso da inflamação pulmonar alérgica, e diversos dados clínicos e experimentais têm identificado potencial participação dos hormônios sexuais femininos na fisiologia respiratória e na resposta das vias aéreas contra agentes ambientais (CARD; ZELDIN, 2009; TICCONI et al., 2013).

Como dito anteriormente, os hormônios sexuais femininos exercem seus papeis regulatórios ligando-se a receptores específicos e interferem em diversas etapas do curso da inflamação alérgica pulmonar como a migração celular, a geração de mediadores e também a 
reatividade das vias aéreas, mas apesar do exposto, os mecanismos que culminam com a deterioração dos sintomas da asma ainda não estão totalmente elucidados (DE OLIVEIRA et al., 2010; KYNYK ; MASTRONARDE; MCCALLISTER, 2011).

Neste estudo, camundongos fêmeas que foram previamente sensibilizadas e desafiadas com OVA foram submetidas à remoção cirúrgica dos ovários (grupo alérgico OVx) ou à falsa cirurgia de remoção dos ovários (grupo alérgico Sahm/OVx). Nestas condições, com a inflamação pulmonar instalada, os animais foram submetidos ao re-desafio com OVA por três dias consecutivos, durante 15 minutos por dia.

A relevância deste modelo experimental recai sobre sua semelhança com o observado em mulheres já asmáticas que entram na pós-menopausa e/ou fazem terapia de reposição hormonal. Nesse sentido, o modelo apresentado pode ser útil para os estudos que visam compreender o efeito modulador dos hormônios sexuais femininos na asma.

Optamos por realizar o estudo em camundongos fêmeas Balb/c, pois a literatura reporta que esta linhagem de animais desenvolve forte resposta à inflamação pulmonar induzida por ovoalbumina (ZHANG, 1997).

Antes do início de nossas investigações, nosso intuito foi verificar a eficácia da ovariectomia e dos tratamentos dos animais com estrógeno, progesterona ou ambos os hormônios neste modelo. Para tanto, os animais foram submetidos à coleta do lavado vaginal para identificação do ciclo reprodutivo e posteriormente à determinação da massa uterina e à quantificação de estrógeno e progesterona circulantes.

A identificação da fase do ciclo reprodutivo neste tipo de estudo é importante, visto que permite investigar a relevância do perfil circulante hormonal e sua potencial influência nos eventos inflamatórios de origem alérgica.

A remoção cirúrgica dos ovários induz alterações no ciclo reprodutivo de maneira que a fase se mantém em diestro (FREEMAN et al., 1988). Além disso, Pinheiro et al. (2011) revelaram que camundongos fêmeas ovariectomizadas exibem redução do volume e da motilidade uterina e atrofia glandular. Goldman e colaboradores (2007) mostraram que o lavado vaginal analisado sob o diestro (Figura 5D) caracteriza-se pela maior presença de leucócitos e nesta fase a concentração de estrógeno circulante começa a se elevar.

Dados anteriores do nosso laboratório também mostraram que o diestro induzido pela carência dos hormônios sexuais femininos após 7 dias de ovariectomia é caracterizado pela reduzida concentração de hormônios sexuais circulantes - estrógeno e progesterona e pelo acúmulo de leucócitos no lavado vaginal. É interessante lembrar que estes dados foram 
obtidos de ratas e posteriormente confirmados em camundongos (ACCETTURI, 2009; DE OLIVEIRA et al., 2007).

Nossos dados revelaram que animais submetidos à ovariectomia apresentaram redução da massa uterina e mantiveram a fase do ciclo sexual em diestro (Figura 4). Neste sentido o modelo de inflamação pulmonar proposto foi conduzido em condições de baixa concentração de hormônios sexuais femininos e de suas conseqüências.

De fato, Decatanzaro et al. (2009) indicam que a determinação da massa uterina é utilizada como importante marcador do papel do estrógeno no organismo. Pinheiro e colaboradores (2011) mostraram que o útero de ratas em proestro tem volume aumentado, e Pinto (1999) verificou que o tratamento de ratas ovariectomizadas com estrógeno aumenta a massa uterina ao induzir a proliferação de células do músculo liso no útero.

Nossos resultados também indicaram que o peso uterino dos animais alérgicos $\mathrm{OVx}$ tratados com estrógeno e com estrógeno + progesterona foi restabelecido. Entretanto, vale deixar claro que os estudos de Pinto (1999) foram conduzidos em ratas e com concentração de estradiol diferente da utilizada em nosso estudo. Assim, para verificar se o aumento do peso do útero dos OVx tratados com estrógeno advém da proliferação das células musculares ou se decorre de acúmulo de líquido no tecido uterino, estudos posteriores avaliando o peso seco do útero dos camundongos utilizados no nosso modelo poderiam ser de interesse.

O perfil celular encontrado no lavado vaginal dos animais alérgicos OVx tratados com estrógeno apresentou acúmulo de células epiteliais nucleadas e aponta para a fase de proestro. De acordo com Goldman e colaboradores (2007), o proestro (Figura 5A) dura aproximadamente 1 dia, e o lavado vaginal é composto por células epiteliais nucleadas, frequentemente de aparência granulosa quando observadas por microscopia de luz. No proestro tem-se o pico de estrógeno e a concentração de progesterona se eleva, chegando ao pico no final da fase.

$\mathrm{O}$ tratamento dos animais alérgicos OVx com progesterona ou com estrógeno + progesterona implicou no acúmulo de poucas células no lavado vaginal, dentre elas leucócitos, células queratinizadas e células epiteliais nucleadas, caracterizando a fase de metaestro. A diferença entre estes dois grupos reside no fato de que no lavado vaginal dos animais tratados com progesterona observamos grande quantidade de muco, enquanto o lavado dos animais tratados com os 2 hormônios encontrou-se límpido. Segundo Smith (2011), a fase de transição entre metaestro e diestro pode ser caracterizada por redução do número de células presentes no lavado e pelo aparecimento de muco, portanto sugere-se que os animais alérgicos OVx tratados com progesterona estivessem nesta fase de transição do 
ciclo. Em síntese, nossos estudos indicaram que o tratamento com estrógeno levou os animais à fase de proestro, enquanto o tratamento dos animais com progesterona ou estrógeno + progesterona induziu a fase de metaestro.

Observamos também que o tratamento com estrógeno aumentou o volume uterino dos animais, enquanto o tratamento com progesterona não causou alteração no volume uterino. Em contrapartida, o tratamento dos animais com estrógeno + progesterona causou aumento significante do volume uterino dos animais. É provável que este aumento observado nos animais alérgicos OVx tratados com estrógeno + progesterona esteja relacionado com estrógeno, visto que os animais que foram tratados apenas com estrógeno também tiveram massa uterina amplificada.

É interessante lembrar que estudos anteriores do nosso grupo mostraram que animais Sham/OVx alérgicos apresentaram resposta inflamatória pulmonar de igual magnitude, independente da fase do ciclo reprodutivo. Por outro lado, o diestro induzido pela OVx, com redução significante da concentração sérica de estrógeno e progesterona, seguido da sensibilização ao antígeno promove alterações importantes no curso da inflamação pulmonar alérgica, como por exemplo a redução da inflamação (ACCETURI, 2009; DE OLIVEIRA et al., 2010; DE OLIVEIRA et al., 2007; RIFFO-VASQUEZ et al., 2007). Neste contexto, é notável que os hormônios sexuais femininos podem exercer efeito pró ou anti-inflamatório. Basicamente, este efeito dual parece estar associado ao perfil dos hormônios sexuais femininos circulantes no momento em que ocorre a sensibilização ao antígeno. Nesse sentido, a compreensão do papel modulador do estrógeno e da progesterona sobre a resposta inflamatória pulmonar torna-se de grande valia.

A determinação da concentração dos hormônios sexuais femininos circulantes nos proporcionou melhor segurança para o estudo, pois verificamos, mais uma vez, a eficácia da ovariectomia pela diminuição da concentração de estrógeno e progesterona nos animais que tiveram seus ovários removidos. Verificamos ainda que o tratamento hormonal dos animais alérgicos $\mathrm{OVx}$ com estradiol, progesterona ou estrógeno + progesterona aumentou a concentração desses hormônios a valores próximos aos encontrados nos animais falsamente operados (alérgicos Sham/OVx).

Referente tratamento hormonal experimental, o papel do estrógeno e da progesterona ainda é contraditório diante do modelo de inflamação pulmonar.

Troisi e colaboradores (1995) e Metcalf e colaboradores (2010) admitem que a terapia de reposição hormonal possa aumentar o risco de mulheres desenvolverem asma na pósmenopausa. Em seus estudos estes autores mostraram que, comparadas às mulheres que nunca 
fizeram reposição hormonal, aquelas submetidas a esta terapia são mais propensas a desenvolverem asma, com riscos ainda maiores para as voluntárias que faziam reposição apenas com estrógeno. Por outro lado, Dimitropulou e colaboradores (2009) afirmam que o tratamento com estrógeno tem efeito anti-inflamatório em modelo murino de asma.

Um exemplo interessante são os estudos conduzidos por Ligeiro de Oliveira e colaboradores (2004). Como mencionado, o perfil hormonal no momento da sensibilização parece ser importante, visto que estes autores observaram que ratas sensibilizadas com 7 dias de ovariectomia exibem menor recrutamento celular para os pulmões após o desafio com OVA em relação às ratas sensibilizados com 1 dia de ovariectomia. O tratamento com estradiol das ratas com 7 dias de ovariectomia piorou a inflamação pulmonar, ao passo que o tratamento das ratas com 1 dia de ovariectomia atenuou a inflamação pulmonar observada nestes animais.

Neste contexto, estudos posteriores do nosso grupo mostraram que a imunização de camundongos fêmeas após 7 dias da ovariectomia não amplifica o recrutamento celular para os pulmões, e repetidas broncoprovocações não são suficientes para causar inflamação pulmonar nos animais (ACCETTURI, 2009).

Vale frisar que neste modelo experimental a imunização e a primeira bateria de desafios ocorreram em concentrações fisiológicas de hormônios sexuais femininos, anteriormente à cirurgia de remoção dos ovários.

No presente estudo mostramos que animais com o processo alérgico previamente instalado e que tiveram remoção dos ovários e posteriormente foram re-expostos ao desafio antigênico desenvolveram aumento significante do recrutamento de células inflamatórias (predominantemente de eosinófilos) para seus pulmões em relação aos animais que permaneceram com seus ovários intactos. Tais resultados permitiam afirmar que a carência dos hormônios sexuais femininos no organismo previamente sensibilizado se associou ao aumento da inflamação pulmonar após um segundo contado com o antígeno, ou seja, após a re-exposição à OVA, contudo não podíamos indicar que a ovariectomia estava regulando este aumento da inflamação.

Diante disto, para verificar se a carência dos hormônios sexuais femininos decorrente da OVx estaria modulando positivamente o aumento da inflamação pulmonar ou se a presença de níveis fisiológicos dos HSF nos animais Sham/OVx é que preveniu seu desenvolvimento, decidimos analisar o efeito da sensibilização e do desafio com OVA sobre o pulmão dos animais anterior à ovariectomia. Para tanto, de acordo com nosso delineamento experimental, o experimento foi executado em animais sensibilizados e desafiados, no dia que seria 
realizada a ovariectomia. Nossos dados mostraram que estes animais tiveram aumento do recrutamento celular para os pulmões, com valores similares ao observado nos alérgicos $\mathrm{OVx}$ re-desafiados, sugerindo que a manutenção fisiológica da concentração dos hormônios sexuais femininos parece atenuar o curso da inflamação alérgica pulmonar, enquanto a carência dos hormônios sexuais femininos não preveniu a piora da inflamação alérgica pulmonar.

Como nossos estudos revelaram maior recrutamento de células inflamatórias para o pulmão dos animais alérgicos $\mathrm{OVx}$ e a re-exposição ao antígeno ocorreu quando a concentração de HSF estava reduzida, então nosso modelo pode ser utilizado para a investigação dos mecanismos envolvidos com a piora da asma em mulheres na pósmenopausa ou naquelas asmáticas submetidas à remoção cirúrgica dos ovários.

Tendo em mente que a flutuação dos hormônios sexuais femininos está relacionada com a modulação da inflamação das vias aéreas e que seu papel durante o curso da asma ainda é controvertido, decidimos tratar os animais alérgicos ovariectomizados com estrógeno, com progesterona ou com estrógeno + progesterona e avaliar o papel destes hormônios na resposta inflamatória causada pela re-exposição de animais alérgicos à OVA.

Nossos dados apontam que a progesterona per se não promove efeito sobre o número total de células recuperadas no lavado broncoalveolar em relação ao observado nos alérgicos $\mathrm{OVx}$, mas que quando associada ao estrógeno (nos animais alérgicos $\mathrm{OVx} \mathrm{E}+\mathrm{P}$ ) previne o recrutamento de células totais para o pulmão. Em contrapartida, nossos dados sugerem papel inflamatório do estrógeno.

De fato, após o re-desafio com OVA, o aumento do número de células recuperadas no lavado broncoalveolar dos animais alérgicos $\mathrm{OVx}$ é semelhante ao observado no lavado broncoalveolar dos alérgicos OVx tratados com progesterona. Por outro lado, um aumento mais acentuado das células totais foi verificado no pulmão dos OVx tratados com estrógeno (Figura 7). Todavia, é importante mencionar que a composição do lavado broncoalveolar dos animais alérgicos Sham/OVx, OVx, $O V x+E$ e $O V x+P$ são diferentes, sendo constituídos de tipos celulares distintos.

Dados da literatura indicam que receptores de estrógeno e de progesterona são encontrados na superfície de leucócitos (NILSSON, 2007). Conforme Zierau et al. (2012), a progesterona pode ativar linfócitos via receptor PR-A ou PR-B e aumentar a migração dessas células para o local da inflamação, ativar mastócitos e provocar a liberação de IgE após estímulo alérgico.

Alguns estudos apontam que o estrógeno pode alterar a expressão de moléculas de adesão no endotélio vascular e na superfície de leucócitos em modelos de artrite reumatóide e 
doenças vasculares (ARNAL et al., 2009; CID et al., 2002). Hamano e colaboradores (1998) examinaram os efeitos dos hormônios sexuais femininos sobre a função de eosinófilos. Estes autores verificaram que o tratamento in vitro de eosinófilos com $\beta$-estradiol aumentou significantemente a adesão dessas células às células endoteliais da mucosa nasal de humanos e ainda, o tratamento com estradiol em combinação com progesterona induziu o aumento da desgranulação dos eosinófilos.

Diante do exposto, uma possível justificativa para as diferenças entre a migração celular para os pulmões dos animais alérgicos seria que os hormônios sexuais femininos possam estar modulando a expressão de moléculas de adesão e a quimiotaxia de leucócitos para o local da inflamação neste modelo (ABARACA-ROJANO et al., 2013; NILSSON, 2007)

Está bem estabelecido que os eosinófilos representam uma das principais células encontradas na região brônquica durante asma. São inúmeros os estudos indicando o papel dos eosinófilos na lesão do epitélio brônquico, na indicação da hiperreatividade brônquica e remodelamento (BOUSQUET et al., 1990; FAHY et al., 2009; LOUTSIOS; FARAHI; PORTER, 2014; NADIF et al., 2013).

De acordo com Lucaks (1995), O infiltrado celular observado no pulmão durante resposta asmática consiste principalmente de neutrófilos e eosinófilos. Com relação a estas células, é interessante notar que nossos resultados indicam que o re-desafio dos animais alérgicos após a redução dos hormônios sexuais femininos circulantes causados pela ovariectomia aumentou o número de eosinófilos, mas não de neutrófilos, recuperados no lavado broncoalveolar dos animais alérgicos $\mathrm{OVx}$.

O tratamento dos animais alérgicos OVx com estrógeno exacerbou o número de neutrófilos, eosinófilos e de células mononucleares, enquanto o tratamento dos animais alérgicos $\mathrm{OVx}$ com progesterona elevou apenas o número de células mononucleares após o re-desafio com OVA.

Nossos dados, portanto, divergem dos observados por Hellings e colaboradores (2003), os quais indicaram que a progesterona induz eosinofilia em modelo murino de inflamação alérgica pulmonar. Por outro lado, nossos dados concorrem aos de Shah et al (2010), que mostram que a terapia de reposição hormonal com estrógeno acarreta aumento do número de eosinófilos no lavado broncoalveolar em modelo murino de asma crônica.

No que diz respeito aos dados da literatura, notamos que poucos estudos investigam os efeitos do tratamento com estrógeno em combinação com progesterona em modelo de inflamação pulmonar. Nossos resultados são interessantes porque o tratamento com o 
estrógeno aumenta acentuadamente a inflamação pulmonar, o tratamento com progesterona mantém a inflamação pulmonar aos valores encontrados nos animais alérgicos OVx e os dois hormônios simultaneamente parecem permitir que o quadro de inflamação pulmonar instalado seja controlado ao ponto dos valores se ajustarem ao observado nos animais alérgicos Sham/OVx. O perfil celular quantificado no lavado broncoalveolar dos animais pode ser observado também pela análise dos cortes histológicos corados com HE (Figura 14).

$\mathrm{Na}$ vigência de um estímulo alérgico, a movimentação de células para o foco inflamatório envolve a mobilização de células da medula óssea em direção ao leito vascular e deste para o pulmão (RANKIN, 2008). Nesse sentido, a partir do momento que os animais alérgicos OVx apresentaram aumento da inflamação pulmonar após a re-exposição à OVA, um outro aspecto importante a ser considerado foi verificar o efeito da modulação do hormônios sexuais femininos sobre a cinética de leucócitos. Para tanto, avaliamos a dinâmica de mobilização de leucócitos circulantes e da medula óssea dos animais alérgicos, redesafiados, com e sem ovários. Estudos sobre o efeito do estrógeno e da progesterona sobre esta mobilização também foram conduzidos.

Com relação às células presentes na medula óssea, nossos dados mostraram que animais alérgicos $\mathrm{OVx}$ apresentaram aumento do número de leucócitos, enquanto os animais alérgicos Sham/OVx apresentam redução do número destas células. É possível que o acúmulo de células na medula óssea dos animais alérgicos OVx advenha de uma maior produção de leucócitos ou de uma falha no mecanismo de recrutamento celular para os pulmões devido ao excesso de células, ficando retidas no compartimento.

Com relação aos leucócitos circulantes, nossos resultados indicaram que os animais alérgicos ovariectomizados tiveram redução do número destas células, mesmo após a reexposição à OVA.

O aumento do número de leucócitos na medula óssea e a redução observada no sangue dos animais do grupo alérgico OVx pode ser indício de que os hormônios sexuais femininos estejam modulando a produção ou liberação de células da medula óssea. Se confirmados, podem justificar o aumento dessas células no espaço broncoalveolar após a broncoprovocação.

No contexto do envolvimento dos hormônios sexuais femininos sobre a mobilização celular, de Oliveira e colaboradores (2007) sugeriram que as taxas de estradiol e progesterona presentes no soro de animais alérgicos podem modular a liberação de citocinas pró e antiinflamatórias no pulmão e direcionar o recrutamento celular para os pulmões após o desafio inalatório. 
Diante do exposto, é interessante indicar que o tratamento dos animais alérgicos $\mathrm{OVx}$ com estrógeno, progesterona ou ambos seguido do re-desafio com OVA causou aumento de leucócitos circulantes e diminuição dos leucócitos presentes na medula óssea quando comparados aos animais submetidos ao mesmo protocolo, que tiveram seus ovários removidos, mas que não receberam tratamento hormonal (grupo alérgico OVx).

De interesse, é que o aumento do número de leucócitos circulantes observado nos animais alérgicos $\mathrm{E}+\mathrm{P}$ foi menos intenso que o observado nos animais tratados isoladamente com estrógeno ou com progesterona; Ainda, a redução do número de leucócitos na medula óssea apresentou-se mais acentuada, mais uma vez assemelhando-se com os dados observados nos animais alérgicos Sham/OVx.

Com relação à contagem diferencial dos leucócitos circulantes, observamos redução do número de células mononucleares nos animais alérgicos OVx re-desafiados em relação ao grupo alérgico e re-desafiado, mas que não teve os ovários removidos (alérgico Sham/OVx).

Por outro lado, o tratamento dos animais com progesterona ou com estrógeno combinado com progesterona causou aumento das células mononucleares circulantes, enquanto o tratamento apenas com estrógeno causou aumento não só de mononucleares, mas também das polimorfonucleares circulantes em relação ao grupo alérgico OVx re-desafiado.

Como dito anteriormente, receptores de estrógeno alfa e beta apresentam diferentes padrões de expressão no organismo. Ademais, relatos na literatura indicam que o receptor beta de estrógeno tem papel modulador sobre a atividade transcricional do receptor alfa e ainda, que mulheres na pós menopausa têm maior expressão de receptores do tipo beta (HALLL; MCDONELL, 1999; MURILLO-ORTIZ et al., 2008; WEIHUA et al., 2000). Estes dados são interessantes porque é possível que a cinética celular esteja associada também à expressão e aos tipos de receptores envolvidos na resposta inflamatória, e pode ser um dos fios condutores para explicar a piora da inflamação pulmonar em mulheres na pós-menopausa e naquelas que fazem reposição hormonal.

É bem documentado que as alterações características da asma são descamação epitelial, espessamento da membrana basal, edema, infiltrado de células mononucleares, neutrófilos e eosinófilos, hipertrofia do músculo liso e grande quantidade de secreção de muco na luz brônquica (BOUSQUET et al., 2000).

Nesse contexto, sabendo que a carência hormonal devido à ovariectomia seguida da re-exposição ao antígeno está associada à inflamação pulmonar dos animais alérgicos $\mathrm{OVx}$, e que o tratamento com estrógeno seguido do re-desafio exacerbou a inflamação alérgica pulmonar, achamos importante verificar os cortes histológicos dos pulmões destes animais. 
Corroborando os dados obtidos por meio do lavado broncoalveolar, a análise dos cortes histológicos dos pulmões corados com HE, apesar de não quantificados, revelam que a remoção dos ovários dos animais previamente alérgicos e sua re-exposição ao antígeno exacerbou o infiltrado celular nos pulmões destes animais. O mesmo foi observado para os animais que receberam tratamento com progesterona. Ainda, um aumento ainda mais acentuado de células foi observado nos cortes histológicos dos animais alérgicos $\mathrm{OVx}$ tratados com estrógeno. No geral, estes dados reforçam o efeito pró-inflamatório dos hormônios sexuais femininos, principalmente do estrógeno, sobre o recrutamento celular para os pulmões. Por outro lado, fortalecendo os resultados obtidos por meio do lavado broncoalveolar, os cortes histológicos de pulmão dos animais alérgicos $\mathrm{OVx}$ tratados com estrógeno + progesterona revelaram redução da migração celular para os pulmões após o redesafio com OVA.

Como dito anteriormente, após a exposição ao estímulo lesivo, mecanismos associados ao reparo e à restauração da estrutura pulmonar são desencadeados. No geral, admite-se que esta resposta é protetora e benéfica (TLIBA et al., 2008). Todavia, num processo inflamatório crônico das vias aéreas, como observado na asma, os mecanismos reparadores podem causar alteração na estrutura pulmonar, evento que se refere ao remodelamento das vias aéreas, e neste contexto, as produções de muco e de colágeno ocupam lugar de destaque (BUSH, 2008; WESTERGREN-THORSSO et al., 2010).

Com relação à produção de muco é razoável supor que o "clearance" mucociliar é importante mecanismo de defesa primária, pois participa do processo de remoção de partículas inaladas e previne os efeitos deletérios da exposição a poluentes, patógenos e alérgenos (MALL, 2008). As secreções brônquicas são produzidas principalmente pelas células de Goblet (células secretoras de muco presentes no epitélio das vias aéreas) e pelas glândulas submucosas (TAGAYA; TAMAOKI, 2007) e são compostas por proteínas como a albumina e mucinas de alto peso molecular, células inflamatórias como macrófagos, mastócitos e eosinófilos, além de lisozimas, imunoglobulinas, secreções lacrimais e água (TRINDADE et al., 2007).

Durante a inflamação, modificações na composição do muco, como maior presença de células inflamatórias e citocinas, alteram as propriedades visco-elásticas e dificultam a função mucociliar (LUND, 1996).

É notável que condições inflamatórias do pulmão estejam associadas à hiperplasia das células de Goblet e ao aumento da sua capacidade secretória (WANG et al., 2010). Sendo assim, a detecção da hiperplasia das células de Goblet, com consequente produção de muco e 
a avaliação do papel dos hormônios sexuais femininos na atividade secretora dessas células torna-se importante ferramenta para o estudo da inflamação pulmonar observada em nosso modelo.

Os dados revelados por meio da análise dos cortes histológicos corados com PAS mostraram que a remoção dos ovários dos animais alérgicos seguida da re-exposição à OVA potencializou a hiperplasia das células produtoras de muco quando comparadas às do grupo alérgico Sham/OVx. O tratamento dos animais alérgicos OVx com estrógeno não alterou, mas o tratamento com progesterona acentuou ainda mais a hiperplasia das células de Goblet. Por outro lado, mesmo após o re-desafio antigênico, os animais OVx tratados com E+P apresentaram apenas discreta hiperplasia das células de Goblet, mostrando efeito atenuador destes hormônios sobre a produção de muco quando administrados simultaneamente.

No âmbito da produção de muco, é interessante lembrar que em estudos anteriores verificamos que animais imunizados e desafiados após 7 dias de ovariectomia não apresentaram hiperplasia das células de Goblet e não desenvolveram inflamação alérgica nos pulmões (ACCETTURI, 2009).

Em conjunto, estes resultados evidenciam a modulação dos hormônios sexuais femininos sobre as células produtoras de muco e afinam a percepção que os hormônios sexuais femininos executam determinada resposta isoladamente, mas quando atuam em conjunto, promovem respostas diferentes.

Frequentemente associado à asma, componentes da matriz extracelular, como o colágeno, têm a capacidade de alterar a função celular, influenciando a desgranulação de mastócitos e eosinóficos entre outros comportamentos celulares (REINHARDT et al., 2005).

Em estudos conduzidos por Weathington e colaboradores (2006), fragmentos de colágeno instilados nas vias aéreas de camundongos resultaram em distensão alveolar, concentrações aumentadas de fator de crescimento endotelial (VEGF) e hipertrofia ventricular. De acordo com Thomas e colaboradores (2007), fragmentos de colágeno podem atrair quimiotaxicamente neutrófilos para o pulmão e regular a inflamação e remodelamento das vias aéreas.

Roche e colaboradores (1989) afirmam que as fibras de colágeno apresentam-se aumentadas nas vias aéreas de asmáticos. Visto que o aumento da deposição de colágeno é fator relevante para o desencadeamento do remodelamento das vias aéreas e muitas vezes contribui para o quadro de piora da função pulmonar, modelos experimentais que investiguem a deposição de colágeno nas vias aéreas revestem-se de importância adicional. 
Os estudos de Burges e colaboradores (2009) apontam para um aumento de depósito de colágeno na região peribrônquica de camundongos expostos ao protocolo de indução de asma com ovoalbumina. Nossos resultados vão ao encontro dos achados de Burges, pois verificamos aumento de fibras colágenas nos pulmões dos animais alérgicos re-desafiados. Entretanto, apesar de não quantificado, foi possível verificar que os pulmões dos animais alérgicos OVx e dos alérgicos OVx tratados com estrógeno não apresentaram diferença de deposição de fibras de colágeno quando comparados ao pulmão dos animais alérgicos Sham/OVx.

Em nossos experimentos, observamos também que o excesso de colágeno depositado nos pulmões dos animais tratados com progesterona foi maior do que o observado nos demais grupos. Vale lembrar que Hellings e colaboradores (2003) observaram que o tratamento com progesterona aumentou a reatividade das vias aéreas em camundongos fêmeas sensibilizadas e desafiadas com OVA. De acordo com estes autores, a deposição de colágeno pode influenciar a piora da função pulmonar.

O tratamento com ambos os hormônios (estrógeno + progesterona), por outro lado, evitou o aumento da deposição de colágeno nos pulmões dos animais em comparação ao observado nos animais do grupo alérgico OVx.

Diante das imagens é possível verificar uma correlação positiva da produção exacerbada de muco e colágeno em resposta à inflamação, na tentativa de proteção do organismo.

Como mencionado anteriormente, a produção de muco e colágeno participam do processo de reparação tecidual que concorrem para o remodelamento (KYNYK; MASTRONARDE; MCCALLISTER, 2011; PAULI, 1989). Uma vez que as variações da concentração circulante de estrógeno e progesterona influenciam a produção de muco e colágeno neste modelo, então pode ser que mulheres asmáticas na pós-menopausa que fazem uso de reposição hormonal sob a contínua exposição ao antígeno estejam propensas a desenvolverem remodelamento das vias aéreas.

Considerando o exposto, achamos relevante avaliar a mecânica respiratória neste modelo. Ainda, estudos acerca do efeito da remoção dos ovários sobre a reatividade das vias aéreas de camundongos fêmeas com inflamação pulmonar alérgica já instalada podem ajudar na compreensão dos mecanismos envolvidos nas alterações da mecânica pulmonar de mulheres asmáticas que entram em contato com o antígeno em condições de reduzida ou falta de hormônios sexuais. 
No que se refere à reatividade das vias aéreas, estudos sugerem que a função pulmonar pode variar conforme o ciclo sexual em pacientes com doenças respiratórias, mas não em mulheres não asmáticas, sugerindo que as concentrações de estradiol e de progesterona podem estar envolvidas no processo do desencadeamento da asma já instalada (TAM et al., 2011). Face aos nossos dados que foram obtidos após a resposta alérgica ser deflagrada, é possível que existam mecanismos adicionais pelos quais o estrógeno e a progesterona continuam modulando a piora da asma já instalada.

Nossos resultados revelaram aumento da reatividade traqueal à metacolina nos animais alérgicos Sham/OVx e OVx. Observamos maior sensibilidade nos animais alérgicos Sham/OVx, que apresentaram aumento da força de contração traqueal em menores concentrações de metacolina. Entretanto, à medida que as concentrações de metacolina aumentaram, particularmente na concentração de metacolina capaz de causar a contração de $50 \%$ da resposta máxima observada nos alérgicos Sham/OVx, a reatividade da traquéia dos animais alérgicos OVx foram se equiparando à observada em traquéias de animais alérgicos Sham/OVx. Eventualmente, pode ser que a carência do estrógeno e da progesterona, provoque o aumento da Ec50, então doses maiores seriam necessárias para produzir efeito similar ao encontrado na traqueia dos animais alérgicos Sham/OVx.

É interessante notar que Haggerty e colaboradores (2003), sugerem que a elevação das concentrações de progesterona ou estrógeno circulantes pode piorar a função pulmonar na asma (HAGGERTY et al., 2003).

Contrariamente aos autores acima, nossos resultados mostraram que o tratamento dos animais alérgicos $\mathrm{OVx}$ com estrógeno ou progesterona atenuou o aumento da reatividade da traqueia à metacolina. Deste modo é razoável supor que os mecanismos regulados pelos hormônios sexuais femininos ligados à piora da inflamação pulmonar podem ser dissociados daqueles que afetam a reatividade das vias aéreas. É importante destacar que experimentos de reatividade in vitro com as traquéias dos animais tratados com estrógeno em conjunto com progesterona também foram realizados, entretanto não conseguimos respostas contráteis à metacolina suficiente para a inserção dos dados no gráfico.

Nossos resultados se alinham aos de Matsubara et al. (2008). Estes autores indicaram que o estrógeno estimula a inflamação pulmonar eosinifílica e inibe a reatividade traqueal após o tratamento de camundongos fêmeas ovariectomizadas e sugerem que inflamação das vias aéreas e a reatividade traqueal podem se apresentar como fenômenos separados.

Estudos realizados por Degano e colaboradores (2001) mostraram que o tratamento de ratas ovariectomizadas com estradiol reduziu a reatividade traqueal frente ao estimulo 
colinérgico nestes animais. Dimitropulou e colaboradores (2009) observaram os mesmos resultados, em modelo murino de asma.

Matsubara e colaboradores (2008) também mostraram que camundongos fêmeas expostos a desafios com OVA por 10 dias, quando ovariectomizadas apresentam aumento da reatividade traqueal frente à metacolina. $\mathrm{O}$ tratamento dos animais $\mathrm{OVx}$ com 17- $\beta$ estradiol também reverteu a hiperatividade traqueal observada nos OVx e a administração diária de ICI 82, 780, um modulador de receptor de estrógeno, causou significante aumento da reatividade desses animais.

Após verificarmos que os hormônios sexuais femininos podem provocar alterações na reatividade traqueal in vitro, decidimos investigar também os efeitos da carência dos hormônios sexuais femininos sobre a mecânica respiratória.

A razão para estes estudos também recaem sobre o fato de que em condições de inflamação pulmonar ocorrem alterações estruturais importantes nos pulmões, as quais modificam a mecânica ventilatória e consequentemente o funcionamento do sistema respiratório como um todo (MAUAD et al., 2000).

De acordo com Farha et al. (2009), em mulheres asmáticas, tanto o volume expiratório forçado no primeiro segundo (FEV1) quanto a capacidade vital forçada (CVF) são menores no período pré ovulatório do ciclo sexual. Corroborando com esta observação, Zimmerman e colaboradores (2000), mostraram que os maiores índices de entradas em departamentos de emergência relacionados à asma, são de mulheres no período que antecede a menstruação. Pallev e colaboradores (1999) verificaram que mulheres asmáticas na pós-menopausa têm piora dos sintomas da asma, e em estudos posteriores estes autores relataram que a reposição de estrógeno não interferiu com volume expiratório forçado destas mulheres (PALLEV et al., 2002).

Apesar dos inúmeros estudos, o papel dos HSF na modulação da função pulmonar e na hiperreatividade das vias aéreas ainda é controverso. Carey e colaboradores (2006) mostraram que camundongos deficientes de receptor $\alpha$ de estrógeno apresentam maior reatividade das vias aéreas in vivo frente à metacolina quando comparados a fêmeas normais.

Os resultados obtidos em nossos estudos mostraram que a carência hormonal causada pela remoção dos ovários se associa ao aumento significante da resistência e da elastância pulmonar nos animais alérgicos $\mathrm{OVx}$, e que o tratamento destes animais com estrógeno ou com progesterona reverteu este fenômeno. De fato observamos que estes animais apresentaram resistência e elastância pulmonar similares às encontradas nos animais alérgicos Sham/OVx. Vale salientar que de forma geral, diante dos demais parâmetros avaliados neste 
estudo, os valores encontrados nos animais tratados com $\mathrm{E}+\mathrm{P}$ foram significantemente menores que os observados nos animais tratados isoladamente com estrógeno ou com progesterona. Apesar do mencionado, no caso da resistência e da elastância pulmonar, os valores obtidos após o tratamento com estrógeno + progesterona se mantiveram similares aos dos animais tratados isoladamente com estrógeno ou progesterona.

O aumento da elastância e da resistência observado nos animais alérgicos OVx pode estar associado ao maior infiltrado de eosinófilos e à deposição de colágeno quantificados no pulmão destes animais.

É intrigante que a intensa produção de colágeno não tenha afetado a mecânica respiratória dos animais alérgicos $\mathrm{OVx}$ tratados com progesterona. Por outro lado, o tratamento dos animais com progesterona melhorou a mecânica respiratória tanto in vitro quanto in vivo, fato que pode estar relacionado com o menor número de eosinófilos recuperados no lavado broncoalveolar destes animais.

Sabe-se que os eosinófilos são células que modulam a resposta inflamatória de origem alérgica, capazes de liberar interleucinas, quimiocinas e fatores de crescimento cujos RNAm e proteínas já foram amplamente identificados, e que participam da resposta imune (KROEGEL et al., 1994).

De acordo com Dimitropulou e colaboradores (2008), em experimentos utilizando aparelhos de ventilação mecânica para pequenos animais (flexivent), camundongos fêmeas ovariectomizadas submetidas a sucessivos desafios com OVA apresentaram aumento da reatividade das vias aéreas frente à metacolina. O tratamento destes animais com estrógeno reverteu o aumento da contração das vias aéreas, entretanto, não preveniu o aumento da permeabilidade vascular observada nestes animais. Os autores sugerem que os dois processos podem estar sendo regulados independentemente, por mecanismos distintos.

É bem estabelecido que os efeitos reguladores dos hormônios sexuais femininos podem agir diretamente sobre o músculo liso das vias aéreas ou, indiretamente, por meio de mediadores inflamatórios no pulmão (TICCONE et al., 2013).

Diante do exposto, os mecanismos pelos quais os animais tratados com estrógeno, que apresentaram aumento significante de eosinófilos no infiltrado celular e intensa deposição de colágeno, mostraram índice de elastância e resistência das vias aéreas semelhantes ao observado nos animais alérgicos Sham/OVx podem ser explicados pelo estudo dos mediadores que envolvem sensibilidade, como aqueles capazes de que causar contração muscular ou relaxamento das vias aéreas, como o óxido nítrico. 
O óxido nítrico é um importante biomarcador da asma e tem papel essencial no relaxamento do músculo liso das vias aéreas (LI et al., 2005).

Sintetizado no organismo por meio da enzima óxido nítrico sintase (NOS) a partir de oxigênio e do aminoácido L-arginina (MIRAGLIA et al., 2011), o óxido nítrico é um radical livre que tem a meia-vida em cerca de 10 a 60 segundos nos tecidos. Devido à sua meia vida curta, a detecção do óxido nítrico em amostras biológicas é detectada por meios alternativos, como por exemplo, pela quantificação de nitritos, método que foi utilizado neste estudo (LI et al., 2005).

Nosso laboratório vem a algum tempo estudando os efeitos do óxido nítrico no organismo, particularmente no que se refere ao tônus das vias aéreas (COELHO; CAVRIANI; SOARES, 2007; LINO-DOS-SANTOS FRANCO et al., 2013; LINO-DOS-SANTOS FRANCO et al., 2006). Lino dos Santos Franco e colaboradores (2013) mostraram que o óxido nítrico tem efeito protetor contra a broncoconstrição causada pela exposição prévia dos animais ao formaldeído seguido da exposição à OVA. Breithaupt-Faloppa et al. (2013) indicaram que o estradiol reduz a inflamação pulmonar de origem indireta provocada pela isquemia e reperfusão intestinal por intermédio do óxido nítrico. De fato, o bloqueio da atividade da enzima óxido nítrico sintase com aminoguanidina reverteu o efeito antinflamatório do estradiol observado em seus experimentos.

Segundo Quiao et al. (2008), o estrógeno pode exercer efeito relaxante nas vias aéreas por meio da geração de NO nas células endoteliais ou exercendo efeitos diretamente na musculatura lisa vascular, tais como angiogênese e alteração da expressão de $\beta$ adrenoceptores nas vias aéreas.

Diante do exposto, outro importante parâmetro a ser analisado seria a relação da ovariectomia sobre a geração de óxido nítrico e de citocinas no compartimento pulmonar. Estudos que utilizam a metodologia de explante pulmonar são interessantes, pois permitem avaliar a geração de mediadores de forma localizada e sem interferência dos sistemas homeostáticos encontrados in vivo.

Nossos resultados mostraram que a re-exposição dos animais alérgicos OVx à OVA não causou alteração na geração de NO pelas células pulmonares dos animais. Por outro lado, o tratamento dos animais com estrógeno ou com progesterona seguidos pela re-exposição ao antígeno aumentou a concentração de nitrito no explante de pulmão dos animais. Considerando que o NO é um importante mediador relaxante do tônus brônquico, é possível que o aumento deste composto no pulmão dos animais tratados com estrógeno ou com 
progesterona esteja associado à menor reatividade da traquéia à metacolina e menor resistência e elastância pulmonar observada nesses animais.

Os animais alérgicos $\mathrm{OVx}$ tratados com $\mathrm{E}+\mathrm{P}$, quando re-expostos ao desafio não apresentaram aumento da geração de NO, mostrando valores similares aos quantificados no explante dos animais alérgicos Sham/OVx, e não tiveram aumento da resistência ou da elastância pulmonar, embora também não tenham apresentado aumento da inflamação das vias aéreas.

Novamente podemos observar que a resposta ao tratamento isolado com estrógeno ou com progesterona se difere do perfil gerado pelo tratamento com estrógeno em conjunto com progesterona.

No que tange as citocinas inflamatórias, nossos dados mostraram que a re-exposição à OVA culminou com o aumento da liberação de IL-4 no explante pulmonar dos animais alérgicos OVx e que o tratamento dos animais OVx com estrógeno ou com progesterona não causou diferença na liberação desta citocina. Porém o tratamento com ambos os hormônios (estrógeno + progesterona) preveniu o aumento da liberação de IL-4 nos pulmões dos animais.

Com relação à progesterona, nossos resultados são opostos aos estudos conduzidos por Hellings e colaboradores (2003). Estes autores mostraram que o tratamento de camundongos fêmeas ovariectomizadas com progesterona aumentou a concentração de IL-4 e IL-5 no lavado broncoalveolar dos animais.

De acordo com Hua et al. (2011) e Saggini et al. (2011), a elevada inflamação pulmonar decorrente da exposição à OVA em camundongos tratados com estrógeno é influenciada pelo aumento de IL-4 e está relacionada ao aumento da geração de IgE e da desgranulação de mastócitos (HUA et al., 2011; KOTSIMBOS et al., 1998; NELMS et al., 1999; SAGGINI et al., 2011).

Nesse contexto, De Oliveira e colaboradores (2007) mostraram que ratas ovariectomizadas, posteriormente sensibilizadas e desafiadas com OVA apresentaram redução da desgranulação de mastócitos, fato que foi revertido pelo tratamento dos animais com estradiol. Assim, é possível que os hormônios sexuais femininos possam ter efeito modulador também na atividade funcional destas células. Visto que em nossos estudos, os resultados acerca da migração celular são opostos aos de Ligeiro de Oliveira, então é possível que, em nosso modelo, a OVx e o tratamento com estrógeno possam também estar modulando os níveis de IL-4 nos pulmões dos animais, a migração celular e estes também estejam associada à desgranulação de mastócitos ou liberação de IgE. Todavia, em nosso modelo, os animais 
que são submetidos à remoção dos ovários já estão com inflamação pulmonar alérgica desencadeada, diferentemente do experimento conduzido por De Oliveira e colaboradores (2007) e, portanto, estudos posteriores que verifiquem a concentração de IgE e a atividade funcional das células inflamatórias seriam de interesse.

Relatos da literatura mostram ainda que a IL-4 tem participação no aumento da quimiotaxia e da ativação de fibroblastos e também na produção de muco pelas células de Goblet (BERGERON et al., 2003; POSTLETHWAITE et al., 1992). Deste modo, a elevada concentração de IL-4 nos animais OVx e nos tratados com estrógeno ou com progesterona pode também estar relacionada com o aumento da síntese de colágeno e da hiperplasia das células de Goblet observada neste estudo.

A IL-5 promove diferenciação de precursores da medula óssea em eosinófilos e também tem papel na ativação e no prolongamento da sobrevida dessas células (STIRLING et al., 2001). Além disso, a IL-5 é responsável pelo sinal de recrutamento de eosinófilos para os pulmões durante a inflamação alérgica (FOSTER et al., 1996; LOPEZ et al., 1988). RiffoVasquez et al (2007), observaram redução de IL-5 no lavado broncoalveolar de animais ovariectomizados e posteriormente sensibilizados e desafiado com OVA. De acordo com esses autores, a capacidade do sistema imune de produzir IL-5 poderia estar prejudicada na vigência de reduzida concentração circulante de hormônios sexuais após a imunização com OVA. Posteriormente, os estudos de Riffo-Vasquez et al. (2007) também mostraram que o tratamento hormonal com benzoato de estradiol restabeleceu os níveis de eosinófilos e IL-5 no pulmão dos animais.

Nossos resultados vão de encontro ao observado pelos autores, visto que observamos aumento de IL-5 no explante dos animais OVx. É importante relembrar que nossos animais foram imunizados na presença de concentrações fisiológicas de hormônios sexuais femininos circulantes. Ainda, nossos estudos mostraram exacerbação da eosinofilia no pulmão desses animais. O tratamento com estrógeno ou com progesterona não interferiu com a geração de IL-5 nos pulmões, e o tratamento com estrógeno+progesterona, apesar de não significante, parece atenuar a geração deste mediador.

Cai et al. (2012) trataram camundongos fêmeas com tamoxifeno, um modulador não seletivo de receptores de estrógeno. Segundo estes autores, o estrógeno induz a produção de citocinas Th2, notadamente IL-5, cujos efeitos se associam ao aumento do recrutamento de eosinófilos para o pulmão. É fato que em nossos experimentos o tratamento dos animais com estrógeno não promoveu diferença em relação ao aumento de IL-5 observado nos animais alérgicos OVx. 
A IL-1 $\beta$ é produzida por diversos tipos celulares como macrófagos, neutrófilos e células epiteliais. Está associada ao recrutamento de neutrófilos e de moléculas de adesão e na indução de outras citocinas inflamatórias (DINARELLO, 2011). Nossos resultados mostraram que a ovariectomia seguida do re-desafio aumentou a concentração de IL-1 $\beta$ no explante pulmonar dos animais. O tratamento dos animais alérgicos com estrógeno ou com progesterona não causou diferença em relação ao observado nos OVx. O tratamento com ambos os hormônios, todavia, reduziu os níveis de IL-1 $\beta$ no explante destes animais.

Os resultados obtidos pela dosagem de IL-4, IL-5 e IL1 $\beta$ nos animais OVx tratados com $\mathrm{E}+\mathrm{P}$ permitem aventar a possibilidade de um papel anti-inflamatório dos hormônios sexuais femininos quando administrados em conjunto.

Pacifici et al. (1989), observaram aumento da geração de IL-1 $\beta$ nos pulmões de mulheres na pós-menopausa e, contrariamente aos nossos resultados, a reposição hormonal com esteróides ovarianos diminuiu os níveis dessa citocina. Além disso, em estudos posteriores Pacifici et al. (1991), indicaram que o estradiol reduz a liberação de IL-1 $\beta$ em cultura de monócitos/macrófagos. Uma possível explicação para esta divergência entre nossos resultados e os obtidos pelos autores é o fato desses experimentos serem realizados em mulheres na pós-menopausa submetidas à reposição de estrógeno, porém sem serem asmáticas. Além disso, esses experimentos foram conduzidos em cultura de monócitos/macrófagos circulantes, enquanto nossos experimentos foram conduzidos em sobrenadante de explante pulmonar. Vale lembrar que no explante pulmonar a arquitetura celular é mais complexa que em culturas isoladas de células. Resultados similares foram observados em relação à liberação de TNF- $\alpha$ em cultura de monócitos/macrófagos de mulheres na pós menopausa (PACIFICI et al., 1991).

No contexto da asma, sabe-se que o TNF- $\alpha$ pode ativar neutrófilos, macrófagos e células endoteliais e está envolvido com o recrutamento celular, indução de hiperreatividade das vias aéreas também pode amplificar a inflamação por mecanismos associados à ativação do NF-кB (KIPS et al., 1993; THOMAS et al., 1995).

Nossos dados mostraram que a ovariectomia seguida do re-desafio aumentou significantemente a concentração de TNF- $\alpha$ no explante dos animais alérgicos OVx, enquanto o tratamento com estrógeno, progesterona ou ambos foi capaz de prevenir este aumento. Neste caso, nossos resultados corroboram os de Pacifici et al (1991) e também os de Burger e Dayer (2002), que indicaram efeito inibitório do estradiol sobre a geração de TNF- $\alpha$ por monócitos e macrófagos. 
Em estudos anteriores mostramos que o explante pulmonar de animais imunizados e desafiados com OVA após 7 dias da ovariectomia gerou menores níveis de IL-13, evidenciando que os hormônios sexuais femininos podem mediar as ações também da IL-13 (ACCETTURI, 2009).

Relatos da literatura revelam que a IL-13 regula a síntese de IgE, a inflamação eosinofílica, a hiperplasia do músculo liso das vias aéreas e das células de Goblet. Ainda, induz o recrutamento de monócitos, macrófagos e células T após o contato com o alérgeno (HOLGATE, 2009). A IL-13 também está implicada com o remodelamento das vias aéreas (HOLGATE, 2009). Ainda, já foi descrito que a IL-13 e pode elevar a concentração de TIMPs (inibidores teciduais de metaloproteinases) nos pulmões, fato que contribui para o aumento da deposição de colágeno nas vias aéreas (ZHAO et al., 2013).

Nossos dados mostraram que os animais alérgicos OVx tiveram aumento significante de IL-13. Este grupo de animais também apresentou elevada inflamação pulmonar e maior deposição de colágeno e hiperplasia das células de Goblet em comparação aos animais Sham/OVx. Tendo em vista a relação dos efeitos da IL-13 com a reatividade das vias aéreas e o aumento desta citocina nos animais alérgicos OVx, nossos dados podem indicar que a carência hormonal está associada ainda, à hiperreatividade traqueal e ao aumento da resistência e elastância pulmonar observada nestes animais.

Muitos estudos estão direcionando atenção especial aos mecanismos adjacentes à contração do músculo liso via Rho/Rho quinase, cujo sistema de sinalização também está ligado à quimiotaxia de neutrófilos e eosinófilos (SCHAAFSMA et al., 2008). A Rho quinase pode ser ativada pela proteína Rho como também pelo ácido aracdônico, liberado pela musculatura lisa em resposta a vários agonistas (SCHAAFSMA et al., 2008). .

Possa et al. (2012) avaliaram o efeito do tratamento crônico com Y-27632, um inibidor altamente seletivo da Rho quinase, sobre a inflamação e a hiperreatividade das vias aéreas de cobaias. Os autores verificaram redução do número de eosinófilos e das respostas máximas de resistência e elastância do sistema respiratório, em relação ao grupo não tratado com Y-27632. Nossos estudos não avaliaram o papel dos hormônios sexuais femininos no sistema Rho/Rho quinase. Todavia, considerando que ao se ligar em seu receptor de membrana, o estrógeno pode interferir com a sinalização intracelular, como por exemplo, com a via do AMPc (LI et al., 2014; TOWSEND et al., 2012), é possível que no nosso modelo, os hormônios sexuais femininos também possam execercer papel modulador sobre a via Rho/Rho quinase. 
Em relação à magnitude da construção da inflamação, há uma linha tênue que delimita a manutenção da homeostasia do organismo e a exacerbação prejudicial da resposta inflamatória, e neste cenário, a IL-10 exerce importante papel sobre controle endógeno de mediadores.

Nesse sentido, sabe-se que a IL-10 tem atividade anti-inflamatória e pode suprimir a produção de citocinas pró-inflamatórias como a IL-1 $\beta$ e a IL-5 (DINARELLO, 2009; DINARELLO, 1997).

De Oliveira e colaboradores (2010) mostraram que o tratamento de ratas OVx alérgicas com estrógeno promoveu aumento da geração de IL-10 em cultura de células do lavado broncoalveolar enquanto o tratamento destes animais com progesterona reverteu este fenômeno, sugerindo potencial efeito pró-inflamatório da progesterona.

Nossos resultados, entretanto, revelaram aumento significante de IL-10 nos animais OVx tratados com progesterona, seguido de um leve aumento - porém significante - dessa citocina nos animais tratados com estrógeno. Este fato poderia justificar porque animais $\mathrm{OVx}$ tratados com progesterona, que apresentaram concentrações elevadas das citocinas próinflamatórias, tiveram menor número de eosinófilos coletados no lavado broncoalveolar e menor reatividade das vias aéreas. Se a intensidade da inflamação pulmonar decorre de ações diretas da progesterona sobre as células geradoras, nossos dados não permitem indicar, mas estudos in vitro sobre o papel do estrógeno ou da progesterona sobre a atividade funcional de eosinófilos seriam de grande valia.

À luz dos nossos resultados, parece evidente a percepção de que os hormônios sexuais femininos modulam de forma diferencial a geração das citocinas e a reatividade das vias aéreas. Admitindo-se esta hipótese, não surpreende que o estrógeno tenha ação antiinflamatória por reduzir a geração de $\mathrm{TNF}-\alpha$, embora tenha efeito pró-inflamatório sobre as demais citocinas.

Estudos clínicos têm demonstrado que o tratamento de pacientes asmáticos com corticosteróides diminui a hiperreatividade das vias aéreas e o infiltrado de células inflamatórias para os pulmões (GEORÉN et al., 2005; NIJKAMP; VAN OOSTERHOUT, 1993).

Durante a manutenção da asma, os glicocorticoides atuam em receptores específicos e suprimem fatores de transcrição que regulam a expressão de genes associados à inflamação e aumentam a transcrição de genes que codificam proteínas anti-inflamatórias, como a IL-10 (BARNES; ADCKOC, 2003). 
Em doenças alérgicas, os corticostróides parecem modular a reatividade brônquica e o infiltrado eosinofílico para os pulmões por mecanismos relacionados à produção de citocinas pelas células inflamatórias. Os receptores de glicocorticóides são membros da superfamília dos receptores nucleares e exercem seus efeitos por meio de fatores de transcrição, resultando em aumento ou diminuição da síntese de proteínas e subsequente alteração da função celular (BARNES; ADCOK, 2003).

De Bie et al. (1996), reportaram que o tratamento prévio de camundongos com dexametasona preveniu o infiltrado de eosinófilos para o fluido broncoalveolar e a hiperreatividade traqueal à metacolina tanto in vitro quanto in vivo após sucessivos desafios com ovoalbumina. Em contraste, os animais submetidos às mesmas sessões de desafios, porém tratados com metirapona, mostraram potente hiperreatividade das vias aéreas frente à metacolina. Investigações realizadas por Schmidt et al. (1994) e Mori et al. (1994) mostraram que o tratamento in vitro de células $\mathrm{Th} 2 \mathrm{CD}^{+}$com dexametasona apontaram diminuição na geração de citocinas inflamatórias.

Em estudos anteriores do nosso laboratório mostramos que ratas imunizadas e desafiadas após 7 dias da ovariectomia tiveram diminuída inflamação das vias aéreas em relação àquelas com os ovários intactos. Posteriormente, mostramos que as ratas com os ovários intactos tratadas com modulador seletivo de receptor de estrógeno (Tamoxifeno) tiveram redução da inflamação das vias aéreas quando comparadas às Sham/OVx não tratadas. Por outro lado, o tratamento dos animais OVx com $17 \beta$-estradiol ou o bloqueio dos efeitos da corticosterona pelo tratamento dos animais OVx com metirapona ou com RU-486 restabeleceu a inflamação alérgica pulmonar destes animais após o desafio antigênico, sugerindo que o estradiol tem efeito pró-inflamatório na resposta alérgica pulmonar, e estas ações parecem ser mediadas pelos glicocorticóides endógenos (LIGEIRO DE OLIVEIRA et al., 2004). Nesse sentido, também é possível supor que em nosso modelo, a carência ou a presença dos HSF após a inflamação pulmonar alérgica já instalada possa estar modulando os mecanismos de controle endógeno da inflamação pulmonar, como por exemplo, a liberação de corticosterona.

De maneira a investigar o potencial envolvimento da corticosterona em nosso modelo de inflamação pulmonar, avaliamos a concentração deste glicocorticóide endógeno no soro dos animais.

Observamos redução da concentração plasmática de corticosterona nos animais alérgicos $\mathrm{OVx}$ e nos alérgicos $\mathrm{OVx}$ tratados com estrógeno. É possível que este evento esteja associado ao aumento da inflamação pulmonar eosinofílica observada nestes animais. 
Em seus estudos, Kalkhoveng et al. (1996) descreveram que elevadas concentrações de progesterona podem interferir com o efeito dos corticosteróides e atenuar a ativação do fator de transcrição NF-kB. De fato, nossos resultados mostraram que os animais alérgicos OVx tratados com progesterona tiveram aumento da concentração de corticosterona e apresentaram baixo migração eosinofílica para os pulmões.

Georén et al. (2005) também inferiram que os glicocorticóides protegem o organismo contra a resposta alérgica inflamatória ao inibir a migração de eosinófilos para os pulmões.

No que tange a migração dos eosinófilos, a redução da geração de IL-5 e o aumento de IL-10 somados ao aumento de corticosterona nos animais tratados com progesterona mais uma vez indicar participação anti-inflamatória deste hormônio sem, entretanto, impedir a deposição de muco e colágeno nos pulmões destes animais.

No geral, nossos dados permitem sugerir que a piora da asma em mulheres na pós menopausa pode ser desencadeada por mecanismos distintos, apresentando-se por meio de diferentes manifestações endotípicas e fenotípicas, que têm como consequência final a obstrução do fluxo aéreo. Em atenção aos efeitos inflamatórios do estrógeno, e ainda do controle negativo da associação do estrógeno com a progesterona em alguns parâmetros da magnitude da doença inflamatória alérgica pulmonar, nossos estudos podem ajudar na compreensão dos mecanismos que levam mulheres asmáticas na pós-menopausa e que fazem reposição hormonal a desenvolverem piora dos sintomas da asma. 


\section{CONCLUSÕES}

- O re-desafio com OVA em camundongos fêmeas alérgicas OVx elevou o desenvolvimento da inflamação pulmonar alérgica da resposta contrátil das vias aéreas,

- O tratamento com estrógeno parece piorar a inflamação pulmonar alérgica com influência na resposta geradora de citocinas no pulmão, enquanto o tratamento com progesterona piora a produção de muco e colágeno

- O tratamento com estrógeno em associação com progesterona parece ter efeito protetor sobre a inflamação pulmonar neste modelo,

- O desencadeamento da resposta inflamatória parece se desenvolver por diferentes mecanismos,

- Há uma possível dissociação entre os mecanismos inflamatórios e a magnitude da mecânica respiratória. 
ABARCA-ROJANO, E.; PACHECO-YÉPEZ, J.; DRAGO-SERRANO, M. E.; CAMPOSRODRÍGUEZ, R. Glucocorticoids and estrogens modulate the NF- $\kappa \mathrm{B}$ pathway differently in the micro- and microvasculature. Medical Hypotheses, v. 81, n. 6, p. 1078-1082, 2013.

ACCETTURI, B. G. Avaliação da expressão de moléculas co-estimuladoras na superfície de células dendríticas de fêmeas ovariectomizadas em modelo murino de asma. 2009. 122 f. Dissertação (Mestrado em Farmacologia) - Instituto de Ciências Biomédicas, Universidade de São Paulo, São Paulo, 2009.

AGACHE, I. O. From phenotypes to endotypes to asthma treatment. Curr. Opin. Allegy Clinical Immunology, v. 3, p. 249-256, 2013.

AKIRA, S.; TAKEDA, K. Toll-like receptor signaling. Nature Reviews Immunology, v. 4, p. 499-511, 2008.

AKIRA, S.; UEMATSU, S.; TAKEUCHI, O. Pathogen recognition and innate immunity. Cell, v. 124, p. 783-801, 2006.

ALMEIDA, T. A.; ROJO, J.; NIETO, P. M.; PINTO, F. M.; HERNANDEZ, M.; MARTÍN, J. D.; CANDENAS, M. L. Tachykinins and tachykinin receptors: structure and activity relationships. Current Medicine Chemistry, v. 15, p. 2045-2081, 2004.

ARNAL, J. F.; LAURELL, H.; FONTAINE, C.; GOURDY, P. Estrogen recptor actions on vascular biology and inflammation: implications on vascular pathophysiology. Climacteric, v. 12, p. 12-17, 2009.

BARNES, P. J.; ADCOK, I. M. How do corticosteroids work in asthma. Annual of Internal medicine, v. 139, p. 356-359, 2003.

BARNES, P. J.; LIEW, F. Y. Nitric oxide and asthmatic inflammation. Immunology Today, v. 16, n. 3, p. 128-130, 1995.

BERGERON, C.; PAGE, N.; JOUBERT, P.; BARBEAU, B.; HAMID, Q.; CHAKIR, J. Regulation of procollagen I (alpha1) by interleukin-4 in human bronchial fibroblasts: a possible role in airway remodelling in asthma. Clinical and Experimental Allergy, v. 33, p. 1389-1397, 2003.

BERNARD, G. R.; ARTIGAS, A.; BRIGHAM, K. L.; CARLET, J.; FALKE, K.; HUDSON, L.; LAMY, M.; LEGALL, J. R.; MORRIS, A.; SPRAGG, R. The American-European Consensus Conference on ARDS. Definitions, mechanisms, relevant outcomes, and clinical trial coordination. American Journal of Respiratory and Critical Care Medicine, v. 149, p. 818-24, 1994.

BEUTLER, B. e RIETSCHEL, E. T. Innate immune sensing and its roots: the story of endotoxin. Nature Reviews Immunology, v. 3, p. 169-76, 2003.

\footnotetext{
${ }^{1}$ De acordo com: ASSOCIAÇÃO BRASILEIRA DE NORMAS TÉCNICAS. NBR 6023: informação e documentação: referências: elaboração. Rio de Janeiro, 2002
} 
BREITHAUPT-FALOPPA, A. C.; FANTOZZI, E. T.; ASSIS-RAMOS, M. M.; VITORETTI, L. B.; COUTO, G. K.; ROSSONI, L. V.; OLIVEIRA-FILHO, R. M.; VARGAFTIG, B. B.; TAVARES-DE-LIMA, W. Protective effect of estradiol on acute lung inflammation induced by an intestinal ischemic insult is dependent on nitric oxide. Shock, v. 40, n. 3, p. 203-209, 2013.

BISHOP, A.; ANDERSON, J. E. NO signaling in the CNS: from the physiological to the pathological. Toxicology, v. 208, n. 2, p. 193-205, 2005.

BORNELÖV, S.; SÄÄF, A.; MELÉN, E.; BERGSTRÖM, A.; MOGHADAM, B. T.; VILLE PULKKINEN, V.; ACEVEDO, N.; PIETRAS, O. C. Rule-Based. Models of the Interplay between Genetic and Environmental Factors in Childhood Allergy. PLoS One, v. 8, n. 11, p. 129-133, 2013.

BREITHAUPT-FALOPPA, A. C.; FANTOZZI, E. T.; ASSIS-RAMOS, M. M.; et al. Protective effect of estradiol on acute lung inflammation induced by an intestinal ischemic insult is dependent on nitric oxide. Shock (Augusta, Ga.), v. 40, n. 3, p. 203-209, 2013.

BRIGHAM, K. L. and MEYRICK, B. Endotoxin and lung injury. The American Review of Respiratory Disease, v. 133, p. 913-927, 1986.

BROSENS, J. J.; TULLET, J.; VARSHOCHI, R.; LAM, E. W. F. Steroid receptor action. Best practice \& Research. Clinical obstetrics \& gynaecology, v. 18, n. 2, p. 265-283, 2004.

CAI, Y.; ZHOU, J.; WEBB, D. C. Estrogen stimulates Th2 cytokine production and regulates the compartmentalisation of eosinophils during allergen challenge in a mouse model of asthma International Archives of Allergy and Immunology, v.158, n. 3, p. 252-260, 2012.

CARD, J. W.; CAREY, M. A.; BRADBURY, J. A.; DEGRAFF, L. M.; MORGAN, D. L.; MOORMAN, M. P.; FLAKE, G. P.; ZELDIN, D. C. Gender differences in murine airway responsiveness and lipopolysaccharide-induced inflammation. The Journal of Immunology, v. 177, p. 621-630, 2006.

CARDOSO, C. C.; RICARDO, V. P.; FRUSSA-FILHO, R. SEGRETI PORTO, C.; ABDALLA, F. M. F. Effects of $17 \beta$-estradiol on expression of muscarinic acetylcholine receptor subtypes and estrogen receptor $\alpha$ in rat hippocampus. European Journal of Pharmacology, v. 634, p. 192-200, 2010.

CAREY, M. A.; CARD, J. W.; BRADBURY, J. A.; MOORMAN, M. P.; HAYKALCOATES, N.; GAVETT, S. H.; GRAVES, J. P.; WALKER, V. R.; FLAKE, G. P.; VOLTZ, J. W.; ZHU, D.; JACOBS, E. R.; DAKHAMA, A.; LARSEN, G. L.; LOADER, J. E.; GELFAND, E. W.; GERMOLEC, D. R.; KORACH, K. S.; ZELDIN, D. C. Spontaneous airway hyperresponsiveness in estrogen receptor-alpha-deficient mice. American Journal of Respiratory Critical Care Medicine, v. 175, n. 2, p.126-135, 2006.

CAROFF, M. and KARIBIAN, D. Structure of bacterial lipopolysaccharides. Carbohydrate Research, v. 338, p. 2431-2434, 2003. 
CAVRIANI, G.; OLIVEIRA-FILHO, R. M.; TREZENA, A. G.; et al. Lung microvascular permeability and neutrophil recruitment are differently regulated by nitric oxide in a rat model of intestinal ischemia-reperfusion. European journal of pharmacology, v. 494, n. 2, p. 241249, 2004.

CHEN, W; MEMPEL, M.; SCHOBER, W.; BEHRENDT, H.; RING, J. Gender difference, sex hormones, and immediate type hypersensitivity reactions. Allergy. v.63, n. 11, p. 14181427, 2008.

CID, M. C.; SCHNAPER, W. H.; KLEINMAN, K. W. Estrogens and the Vascular Endothelium. Annais of N. Y. Academy Science, v. 66, p.143-157, 2002.

COELHO, F. R.; CAVRIANI, G.; SOARES, A. L.; et al. Lymphatic-borne IL-1beta and the inducible isoform of nitric oxide synthase trigger the bronchial hyporesponsiveness after intestinal ischema/reperfusion in rats. Shock, v. 28, n. 6, p. 694-699, 2007.

COLLINS, R. A. Site of inflammation influences site of hyperresponsiveness in experimental asthma. Respiratory Physiology and Neurobiology, v. 139, p. 51-61, 2003.

CORTELING, R.; WYSS, D.; TRIFILIEFF, A. In vivo models of lung neutrophil activation. Comparison of mice and hamsters. BMC Pharmacology, v. 2, p. 1-8, 2002.

CUZZOCREA, S.; MAZZON, E.; SAUTEBIN, L.; SERRAINO, I.; DUGO, L.; CALABRO, G.; CAPUTI, A. P.; MAGGI, A. The protective role of endogenous estrogens in carrageenaninduced lung injury in the rat. Molecular Medicine, v. 7, p. 478-487, 2001.

DATASUS. Banco de Dados do Sistema Único de Saúde. www.datasus.gov.br.

DE BIE, J. J.; HESSEL, E. M.; VAN ARK, I.; VAN ESCH, B.; HOFMAN, G.; NIJKAMP, F. P.; VAN OOSTERHOUT, A. J. M. Effect of dexamethasone and endogenous corticosterone on airway hyperresponsiveness and eosinophilia in the mouse. British Journal of Pharmacology, v. 119, p. 1484-1490, 1996.

DECATANZARO, D.; KHAN, A.; BERGER, R.G.; LEWIS, E. Exposure to developing females induces polyuria, polydipsia, and altered urinary levels of creatinine, 17 betaestradiol, and testosterone in adult male mice (Mus musculus). Hormones Behavior, v. 55, n. 1, p. 240-247, 2009.

DEGANO, B.; PRÉVOST, M.C.; BERGER, P.; MOLIMARD, M.; PONTIER, S.; RAMI, J.; ESCAMILLA, R. Estradiol decreases the acetylcholine-elicited airway reactivity in ovariectomized rats through an increase in epithelial acetylcholinesterase activity. American Journal of Respiratory Critical Care Medicine, v.164, n. 10, p. 1849-1854, 2001.

DE OLIVEIRA, A. P. L.; DOMINGOS, H. V.; CAVRIANI, G.; DAMAZO, A. S.; DOS SANTOS FRANCO, A. L.; OLIANI, S. M.; OLIVEIRA-FILHO, R. M.; VARGAFTIG, B. B.; DE LIMA, W. T. Cellular recruitment and cytokine generation in a rat model of allergic lung inflammation are differentially modulated by progesterone and estradiol. American Journal of Physiology. Cellular Physiology, v. 293, p. 1120-1128, 2007. 
DE OLIVEIRA, A. P.; PERON, J. P.; DAMASO, A. S.; FRANCO, A. L.; DOMINGOS, H. V.; OLIANI, S. M.; OLIVEIRA-FILHO, R. M.; VARGAFTIG, B. B.; TAVARES-DELIMA, W. Female sex hormones mediate the allergic lung reaction by regulating the release of inflammatory mediators and the expression of lung E-selectin in rats. Respiratory Research, v. 11, p. 72-76, 2010.

DIMITROPOULOU, C. 1.; DRAKOPANAGIOTAKIS, F.; CHATTERJEE, A.; SNEAD, C.; CATRAVAS, J. D. Estrogen replacement therapy prevents airway dysfunction in a murine model of allergen-induced asthma. Lung, v. 187, n. 2, p. 116-127, 2009.

DINARELlO, C. A. Proinflammatory cytokines. Chest, v. 118, n. 2, p. 503-508, 2000.

ELLMANN, S.; STICHT, H.; THIEL, F.; BECKMANN, M. W.; STRICK, R.; STRISSEL, P. L. Estrogen and progesterone receptors: from molecular structures to clinical targets. Cell Molecular Life Science, v. 66, p. 2405- 2416, 2009.

FALLER, S. et al. Inhaled hydrogen sulfide protects against lipopolysaccharide-induced acute lung injury in mice. Medical gas research, v. 2:26, p. 1-6, 2012.

FARHA, S.; ASOSINGH, K.; LASKOWSKI.; HAMMEL, J.; DWEIK, R.A.; WIEDEMANN, H.P.; ERZURUM, S.C. Effects of the menstrual cycle on lung function variables in women with asthma. American Journal of Respiratory Critical Care Medicine, v. 180, p. 304-310, 2009.

FISH, E. N. The X-files in immunity: sex-based differences predispose immune responses. Nature Reviews Immunology, v. 8, p. 737-744, 2008.

FISCHER, A.; FOLKERTS, G.; GEPPETTI, P.; GRONEBERG, D.A. Mediators of asthma: nitric oxide. Pulmonary Pharmacology Therapy, v. 15, n. 2, p. 73-81, 2002.

FREEMAN, M. E. The ovarian cycle of the rat. Physiology of reproduction, v. 12, p. 18931928, 1988.

GALLI, S. J.; TSAI, M.; PILIPONSKI, A. M. The development of allergic inflammation. Nature, v. 454, n. 7203, p. 445-454, 2008.

GEHA, R.S.; JABARA, H.H.; BRODEUR, S.R. The regulation of immunoglobulin E classswitch recombination. Nature Reviews Immunology, v. 3, n. 9, p. 721-732, 2003.

GEORÉN, S.; AHNBLAD, P.; STJÄRNE, P.; WIKSTRÖM, A. C.; STIERNA, P. Significance of endogenous glucocorticoid sensitivity for airway eosinophilia in a murine model of allergy. Acta Otolaryngology, v. 125, n. 4, p. 378-385, 2005.

GIBSON, P. G.; SIMPSON, J. L.; SALTOS, N. Heterogeneity of airway inflammation in persistent asthma: evidence of neutrophilic inflammation and increased sputum interleukin-8. Chest, v. 119, n. 1329-1336, 2011.

GIMENES-JÚNIOR, J. A. Papel dos hormônios sexuais femininos na inflamação pulmonar aguda e na reatividade das vias aéreas após instilação nasal de LPS em 
camundongos. 2013. 161 f. Tese (Doutorado em Farmacologia) - Instituto de Ciências Biomédicas, Universidade de São Paulo, São Paulo, 2013.

GINA. 2014. Global initiative for asthma. Disponível em: 〈http://www.ginasthma.org>. Acesso em: 10 out. 2013.

GOLDMAN, J. N.; MURR, A. S.; COOPER, R. L. The rodent estrous cycle: characterization of vaginal cytology and its utility in toxicological studies. Developmental and Reproduction Toxicology, v. 80, n. 2, p. 84-97, 2007.

GOSENS, R.; ROSCIONI, S. S.; DEKKERS, B. G.; PERA, T.; SCHMIDT, M.; SCHAAFSMA, D.; ZAAGSMA, J.; MEURS, H. Pharmacology of airway smooth muscle proliferation. European Journal of Pharmacology, v. 585, n. 2, p. 385-397, 2008.

HALL, J. M.; MCDONNELL, D. P. The Estrogen Receptor $\beta$-Isoform (ER $\beta$ ) of the human estrogen receptor modulates ER $\alpha$ transcriptional activity and is a key regulator of the cellular response to estrogens and antiestrogens. Endocrinology, v. 140, n. 12, p. 566-578, 1999.

HAMANO, N.; TERADA, N.; MAESAKO, K.; NUMATA, T.; KONNO, A. Effect of sex hormones on eosinophilic inflammation in nasal mucosa. Allergy Asthma Proceedings, v. 5, p. 263-269, 1998.

HANLEY, S. P. Asthma variation with menstruation. British Journal Dis. Chest, v. 75, p. 306-308, 1981.

HEDRICH, C. M.; BREAM, J. H. Cell type-specific regulation of IL-10 expression in inflammation and disease. Immunologic Research, v. 47, n. 1-3, p. 185-206, 2010.

HEWITT, S. C.; HARRELL, J. C.; KORACH, K. S. Lessons in estrogen biology from knockout and transgenic animals. Annual Review of Physiology, v. 67, p. 285-308, 2005.

HELliNGS, P. W.; VANDEKERCKHOVE, P.; CLAEYS, R.; BILLEN, J.; KASRAN, A.; CEUPPENS, J.L. Progesterone increases airway eosinophilia and hyper-responsiveness in a murine model of allergic asthma. Clinical and Experimental Allergy, v. 33, n. 10, p. 14571463, 2003.

HOlgate, T. S. Novel targets of therapy in asthma. Current Opinion Pulmonary Medicine, v. 15, p. 63-71, 2009.

HUA, X.; KELLY, D.; JANKI, Y.; PATEL, L.; WARREN, C.; NASELSKY, L.; STEPHEN, L.; TILLEY, L. IL-4 Amplifies the Pro-Inflammatory Effect of Adenosine in Human Mast Cells by Changing Expression Levels of Adenosine Receptors. PLoS One, v. 6, n. 9, p. 254259, 2011.

IVANOVA, M. M.; MAZHAWIDZA, W.; DOUGHERTY, S. M.; MINNA, J. D.; KLINGE, C. M. Activity and intracellular location of estrogen receptors a and $b$ in human bronchial epithelial cells. Molecular Cell Endocrinology, v. 305, p. 12-21, 2009. 
JALA, V. R.; RADDE, B. N.; BODDULURI HARIBABU, B.; KLINGE, C. M. Enhanced expression of G-protein coupled estrogen receptor (GPER/GPR30) in lung cancer. BMC Cancer, v. 624, p. 12-15, 2012.

JANEWAY, C. A.; MEDZHITOV, R. Innate immune recognition. Annual Review of Immunology, v. 20, p. 197-216, 2002.

JOHNSTON, G. R.; WEBSTER, N. R. Cytokines and the immunomodulatory function of the vagus nerve. British Journal Anesthesiology, v. 102, n. 4, p. 453-462, 2009.

JOOS, G. F.; GERMONPRÉ, P. R.; PAUWELS, R. A. Neural mechanisms in asthma. Clinical Experimental Allergy, v. 1, p. 60-65, 2000.

KAHKHOVENG, E.; WISSINK, S.; VAN DEN SAAG, P. T.; VAN DEN BURG, B. Negative interaction between the REL A subunit of $\mathrm{nfkb}$ and progesterone receptor. Biological Chemistry, v. 271, p. 213-217, 2011.

KANAZAWA, H. Anticholinergic agents in asthma: chronic bronchodilator therapy, relief of acute severe asthma, reduction of chronic viral inflammation and prevention of airway remodeling. Current Opinion Pulmonary Medicine, v. 1, p. 60-67, 2006. Revisão.

KIM, Y.; LEE, S.; KIM, Y.S.; LAWLER, S.; GHO, Y.S.; KIM, Y.K.; HWANG, H.J. Regulation of Th1/Th2 cells in asthma development: a mathematical model. Mathematical Bioscience Engineering, v. 10, n. 4, p. 1095-1113, 2013.

KIM, S. R. Involvement of sirtuin 1 in airway inflammation and hyperresponsiveness of allergic airway disease. Journal of Allergy and Clinical Immunology, v. 125, p. 449-60, 2010.

KIPS, J. C.; TAVERNIER, J. H.; JOOS, G. F.; PELEMAN, R. A.; PAUWELS, R. A. The potential role of tumour necrosis factor alpha in asthma. Clinical Experimental Allergy, v. 23, n. 4, p. 247-250, 1993.

KOEHLER, F. K.; NILSSON, S. Oestrogen Receptors and Selective Oestrogen Receptor Modulators: Molecular and Cellular Pharmacology. Basic \& Clinical Pharmacology \& Toxicology, v. 96, n. 1, p. 15-25, 2005.

KOTSIMBOS, A. T.; HAMID, Q. IL-5 and IL-5 receptor in asthma. Memorial Instituto Oswaldo Cruz, v.2, p. 75-91, 1997.

KROEGEL, C.; VIRCHOW, J. C.; LUTTMANN, W.; WALKER, C.; WARNER, J. A. Pulmonary immune cells in health and disease: the eosinophil leucocyte (Part I). European Respiratory Journal, v. 7 n. 3, p. 519-543, 1994.

KYNYK, J. A.; MASTRONARDE, J. G.; MCCALLISTER, J. W. Asthma, the sex difference. Current Opinion Pulmonary Medicine, v. 17, n. 1, p. 6-11, 2011.

KUMAGAI, Y.; TAKEUCHI, O.; AKIRA, S. Pathogen recognition by innate receptors. Journal of Infection and Chemotherapy, v. 14, p. 86-92. 2008. 
LAPPALAINEM, U.; WHITSETT, J. A.; WERT, S. E.; TICHELAAR, J. W.; BRY, K. Interleukin-1 Causes Pulmonary Inflammation, Emphysema, and Airway Remodeling in the Adult Murine Lung American Journal of Respiratory Cell and Molecular Biology, v. 32, n. 4, p. 311-318, 2005.

LEVIN, E. R. Minireview: extranuclear steroid receptors: roles in modulation of cell functions. Molecular Endocrinology, v. 25, p. 377-384, 2011.

LI, P. C.; SHAW, C. F.; KUO, T. F.; CHIEN, C. T.Inducible nitric oxide synthase evoked nitric oxide counteracts capsaicin-induced airways smooth muscle contraction, but exacerbates plasma extravasation. Neuroscience Letters, v. 378, p. 117-122, 2005.

LI, T.; XIAO, X.; ZHANG, J.; ZHU, Y.; HU, Y.; ZANG, J.; LU, K.; YANG, T.; GE, H.; PENG, X.; LAN, D.; LIU, L. Age- and sex-differences in vascular responsiveness in healthy and trauma patients: contribution of estrogen receptor-mediated Rho kinase and PKC pathways. American Journal of Physiology Heart Circulatory Physiology, 2014. [Epub ahead of print].

LIGEIRO DE OLIVEIRA, A. P.; OLIVEIRA-FILHO, R. M.; DA SILVA, Z. L.; BORELLI, P.; TAVARES DE LIMA, W. Regulation of allergic lung inflammation in rats: interaction between estradiol and corticosterone. Neuroimmunomodulation, v. 11, p. 20-27, 2004.

LINO DOS SANTOS FRANCO, A.; DAMAZO, A. S.; BERALDO DE SOUZA, H. R.; DOMINGOS, H. V.; OLIVEIRA-FILHO, R. M.; OLIANI, S. M.; COSTA, S. K.; TAVARES DE LIMA, W. Pulmonary neutrophil recruitment and bronchial reactivity in formaldehydeexposed rats are modulated by mast cells and differentially by neuropeptides and nitric oxide. Toxicology Applied Pharmacology, v. 214, p. 35-42, 2006.

LINO-DOS-SANTOS-FRANCO, A.; GIMENES-JÚNIOR, J. A.; LIGEIRO-DE-OLIVEIRA, A. P.; BREITHAUPT-FALOPPA, A. C.; ACCETURI, B. G.; VITORETTI, L. B.; MACHADO, I. D.; OLIVEIRA-FILHO, R. M.; FARSKY, S. H.; MORIYA, H. T.; TAVARES-DE-LIMA, W. Food and Chemical Toxicology, v. 59, p. 731-738. 2013.

LOUTSIOS, C.; FARAHI, N, PORTER, L.; Lock, L. S. Biomarkers of eosinophilic inflammation in asthma. Expert Reviews Respiratory Medicine, v. 2, p. 143-150. 2014.

LOTVALL, J.; AKDIS, C. A.; BACHARIER, L. B.; BJERMER, L.; CASALE, T. B.; ADNAN CUSTOVIC, A.; ROBERT F. LEMANSKE, R. F.; ANDREW J. WARDLAW, A. J.; WENZEL, S. E.; GREENBERGER, P. A. Asthma endotypes: A new approach to classification of disease entities within the asthma syndrome. The Journal of Allergy and Clinical Immunology, v. 127, n. 2, p. 355-360, 2011.

LUH, S. P.; CHIANG, C. H. Acute lung injury/acute respiratory distress syndrome (ALI/ARDS): the mechanism, present strategies and future perspectives of therapies. Journal of Zhejiang University. Science, v. 8, p. 60-69, 2007.

LUND, V. J. Nasal physiology: Neurochemical receptors, nasal cycle, and ciliary action. Allergy Asthma Proceedings, v. 17, n. 4, p. 179-184, 1996. 
MARRIOTT, I.; BOST, K. L.; HUET-HUDSON, Y. M. Sexual dimorphism in expression of receptors for bacterial lipopolysaccharides in murine macrophages: a possible mechanism for gender-based differences in endotoxic shock susceptibility. Journal of Reproductive Immunology, v. 71, p. 12-27, 2006.

MARTINS, I. O. Influência dos hormônios sexuais femininos no remodelamento e na reatividade das vias aéreas em modelo murino de inflamação pulmonar alérgica crônica. 2013. 105 f. Tese (Doutorado em Farmacologia) - Instituto de Ciências Biomédicas, Universidade de São Paulo, São Paulo, 2013.

MASSARO, D.; MASSARO, G. D. Estrogen receptor regulation of pulmonary alveolar dimensions: alveolar sex dimorphism in mice. American Journal of Physiology. Lung Cell Molecular Physiology, v. 290, p. 866-870, 2006.

MATSUBARA, S.; SWASEY, C.; LOADER, J.; DAKHAMA, A.; JOETHAM, A.; OHNISHI, H.; BALHORN, A.; MIYAHARA, N.; TAKEDA, K. AND GELFAND, E. Estrogen Determines Sex Differences in Airway Responsiveness after Allergen Exposure. American Journal of Respiratory Cell Molecular Biology, v. 38, p. 501-508, 2008.

MAUAD, T.; LOPES DE SOUZA, A.; SALDIVA, P.; DOLHNIKOFF, M. Journal of Pneumology, v. 26, n. 2, p. 284-288, 2000.

MEDZHITOV, R.; PRESTON-HURLBURT, P.; JANEWAY, C. A. A human homologue of the Drosophila Toll protein signals activation of adaptive immunity. Nature, v. 388, p. 394397, 1997.

MEURS, H.; GOSENS, R.; ZAAGSMA, J. Airway hyperresponsiveness in asthma: lessons from in vitro model systems and animal models. The European Respiratory Journal, v. 32, n. 2, p. 487-502, 2008.

MIRAGLIA DEL GIUDICE, M.; MARSEGLIA, G. L.; LEONARDI, S.; TOSCA, M. A.; MARSEGLIA, A.; PERRONE, L.; CIPRANDI, G. Fractional exhaled nitric oxide measurements in rhinitis and asthma in children. International Journal of Immunopathology and Pharmacology, v. 4, p. 29-32, 2011.

MORI, A.; SUKO, M.; NISHIZAKI, Y.; KAMINUMA, O.; MATSUZAKI, G.; ITO, K.; ETOH, T.; NAKAGAWA, H.; TSURUOKA, N.; OKUDAIRA, H. Regulation of interleukin5 production by peripheral blood mononuclear cells from atopic patients with FK506, cyclosporin A and glucocorticoid. International Archives of Allergy Immunology, v. 104, p. 32-35, 2010.

MURILLO-ORTIZ, B.; PÉREZ-LUQUE, E.; MALACARA, J. M.; BENÍTEZ-BRIBIESCA, L. Expression of Estrogen Receptor Alpha and Beta in Breast Cancers of Pre- and Postmenopausal Women. Pathology \& Oncology Research, v. 14, n. 4, p. 435-442, 2008.

MURRAY, R. K.; BENDER, D. A.; KATHLEEN, M. B.; PETER, J. K.; VICTOR, W. R. Bioquímica ilustrada de Harper. 29. ed. Editora Lange, 2013. p. 502-205. 
NADIF, R,; ZERIMECH, F.; BOUZIGON, E.; MATRAN, R. The role of eosinophils and basophils in allergic disease considering genetic findings. Current Opinion Allergy Clinical Immunology, v. 5, p. 507-513, 2013.

NICOD, L. P. Cytokines. 1. Overview. Thorax, v. 48, n. 6, p. 660-667, 1993.

NIJKAMP, F. P.; FOLKERTS, G. Nitric oxide and bronchial reactivity. Clinical and Experimental Allergy, v.24, n.10, p. 905-914, 1995.

NIJKAMP, F. P.; VAN OOSTERHOUT, A. J. M. Mechanisms of action of glucocorticoids in the treatment of asthma. In Topics in Pharmaceutical Sciences, v. 21, p. 77-88, 1993.

NILSSON, O. Modulation of the inflammatory response by estrogens with focus on the endothelium and its interactions with leukocytes. Inflammation Research, v. 56, n. 7, p. 269273, 2007.

NISWENDER, G. D. Molecular control of luteal secretion of progesterone. Reproduction, v. 123, n. 3, p. 333-339, 2002.

O'BYRNE, P. M. Role of monoclonal antibodies in the treatment of asthma. Can. Respiratory Journal, v. 20, n. 1, p. 23-25, 2013.

OLIVEIRA, A. P. L.; PERON, J.; LINO-DOS-SANTOS-FRANCO, A.; ACCETURI, B.G.; VIEIRA, R. ; IBANEZ, O. M.; CABRERA, W.; FRANCO, M.; RIZZO, L. ; Vargaftig, B.B.; TAVARES DE LIMA, W. Ovariectomized OVA-sensitized mice display increased frequency of CD4+Foxp3+ T regulatory cells in the periphery. Plos One, v. 6, p. 65-69, 2013.

OH, S. W.; MYUNG, S. K.; PARK, J. Y.; LYM, Y. L.; JU, W. Hormone therapy and risk of lung cancer: a meta-analysis. Journal of Women and Health, v. 19, p. 279-288, 2010.

PACIFICI, R.; RIFAS, L.; MCCRACKEN, R.; VERED, I.; MCMURTRY, C.; AVIOLI, L. V.; PECK, W. A. Ovarian steroid treatment blocks a postmenopausal increase in blood monocyte interleukin 1 release. Proceedings of the National Academy Sciences of the United States of America, v. 86, p. 2398-2402, 1989.

PALEEV, N. R.; CHEREǏSKAIA, N .K.; SLIVETS, O. N.; SHAPOVALENKO, S. A.; PODREZOVA, L. A. Integrative study of bronchial asthma in perimenopausal women. Vestn. Ross. Akademy Medicine Nauk., v. 2, p.16-20, 2002.

PALEEV, N. R.; SHABALIN, V. N.; CHEREǏSKAIA, N. K.; IURINA, T. M.; SLIVETS, O. N.; SHAPOVALENKO, S. A. Specific aspects of the course of bronchial asthma therapy in perimenopausal period. Klin. Medicine (Mosk), v. 77, n. 5, p. 17-20, 1997.

PAULI, B. D.; REID, R. L.; MUNT, P. W.; WIGLE, R. D.; FORKERT, L. Influence of the menstrual cycle on airway function in asthmatic and normal subjects. American Review of Respiratory Disease, v. 140, p. 358-362, 1989.

PEREIRA-VEGA, A.; SÁNCHEZ RAMOS, J.; VÁZQUEZ OLIVA, R.; MALDONADO PÉREZ, J. A.; OLBAH, M. A.; MONTERO FERNÁNDEZ M, VÁZQUEZ RICO, I.; ROBLES RODRÍGUEZ, J. L.; IGNACIO GARCÍA, J. M.; ROMERO PALACIOS, P.; 
MEDINA GALLARDO, J F. Premenstrual asthma and female sex hormones. Journal of Investigation Allergology and Clinical Immunology, v. 22, n. 6, p. 437-439, 2012.

PINHEIRO, A.; CAVES, A.; PAIVA, H.; CORREIA, L.; ALEXANDRE, M.; VILLAR, M. 2011. Fisiologia das Gônadas Femininas. Disponível em: <http://members.tripod.com/ Medman_1/ovariectomia.html>. Acesso em: 10 out. 2013.

POLTORAK, A.; SMIRNOVA, I.; HE, X.; LIU, M. Y.; VAN HUFFEL, C.; MCNALLY, O.; BIRDWELL, D.; ALEJOS, E.; SILVA, M.; DU, X.; THOMPSON, P.; CHAN, E. K.; LEDESMA, J.; ROE, B.; CLIFTON, S.; VOGEL, S. N.; BEUTLER, B. Genetic and physical mapping of the LPS locus: identification of the Toll-4 receptor as a candidate gene in the critical region. Blood Cells, Molecules \& Diseases, v. 24, p. 340-355, 1998.

POSSA, S. S.; CHARAFEDDINE , H. T.; RIGHETTI, R. F.; ANGELI DA SILVA, P.; ALMEIDA-REIS, R.; SARAIVA-ROMANHOLO, B. M.; PERINI, A.; PRADO, C. M.; LEICK-MALDONADO, E. A.; MARTINS, M. A.; TIBÉRIO, I de F. Rho-kinase inhibition attenuates airway responsiveness, inflammation, matrix remodeling, and oxidative stress activation induced by chronic inflammation. American Journal of Physiology - Lung Cellular and Molecular Physiology, v. 303, p. 939-952, 2012.

POSTLETHWAITE, A. E.; HOLNESS, M. A.; KATAI, H.; RAGHOW, R. Human fibroblasts synthesize elevated levels of extracellular matrix proteins in response to interleukin 4. Journal of Clinical Investigation, v. 90, p. 1479-1485. 1992.

PRADO, C. M.; LEICK-MALDONADO, E. A.; ARATA, V.; et al. Neurokinins and inflammatory cell iNOS expression in guinea pigs with chronic allergic airway inflammation. American journal of physiology. Lung cellular and molecular physiology, v. 288, n. 4, p. 741-748, 2005.

QAMAR, A.; RADER, D. J. Effect of interleukin $1 \beta$ inhibition in cardiovascular disease. Current Opinion Lipidol, v. 6, p. 548-553, 2012.

QIAO, X.; MCCONNELL, K. R.; KHALIL, R. A. Sex steroids and vascular responses in hypertension and aging. Gender Medicine, v. 5, p. 46-64, 2008.

REINHARDT, A. K.; BOTTOMS, S. E.; LAURENT, G. J.; MCANULTY, R. J. Quantification of collagen and proteoglycan deposition in a murine model of airway remodelling. Respiratory Research, v. 8, p. 26-30, 2005.

REAL, F. G.; SVANES, C.; OMENAAS, E. R.; ANTÒ, J. M.; PLANA, E.; JARVIS, D.; JANSON, C.; NEUKIRCH, F.; ZEMP, E.; DRATVA, J.; WJST, M.; SVANES, K.; LEYNAERT, B.; SUNYER, J. Lung function, respiratory symptoms, and the menopausal transition. Journal of Allergy Clinical Immunology, v. 121, n. 1, p. 72-80, 2008.

REINHARDT, A. K.; BOTTOMS, S. E.; LAURENT, G. J.; MCANULTY, R. J. Quantification of collagen and proteoglycan deposition in a murine model of airway remodeling. Respiratory Research, v. 8, p. 6-30, 2005. 
REIS E SOUSA, C. Dendritic cells in a mature age. Nature Reviews Immunology, v. 6, n. 6, p. 476-483, 2006

RICHARDSON, J.; BÉLAND, J. Nonadrenergic inhibitory nervous system in human airways. Journal of Applied Physiology, v. 41, p. 764-771, 1976.

RIFFO-VASQUEZ, Y.; LIGEIRO DE OLIVEIRA, A. P.; PAGE, C. P.; SPINA, D.; TAVARES DE LIMA, W. Role of sex hormones in allergic inflammation in mice. Clinical and Experimental Allergy, v. 37, p. 459-470, 2007.

ROCHA DA LAPA, F.; LIGEIRO DE OLIVEIRA, A. P.; ACCETURI, B. ; MARTINS, I.; DOMINGOS, H.; de ALMEIDA CABRINI, D.; TAVARES DE LIMA, W.; SANTOS, A. R. $S$. Anti-inflammatory effects of inosine in allergic lung inflammation in mice: evidence for the participation of adenosine A2A and A3 receptors. Purinergic Signalling, v. 9, n. 6, p. 325-336, 2013.

ROCHE, W. R.; BEASLEY, R.; WILLIAMS, J. H.; HOLGATE, S. T. Subepithelial fibrosis in the bronchi of asthmatics. Lancet, v. 1, p. 520-524, 1989.

SAGGINI, A.; MACCAURO, G.; TRIPODI, D.; DE LUTIIS, M. A.; CONTI, F.; FELACO, P.; FULCHERI, M.; GALZIO, R.; CARAFFA, A.; ANTINOLFI, P.; FELACO, M.; PANDOLFI, F.; SABATINO, G.; NERI, G.; SHAIK-DASTHAGIRISAHEB, Y. B. Allergic inflammation: role of cytokines with special emphasis on IL-4. International Journal of Immunopathology and Pharmacology, v. 24, n. 2, p. 305-311, 2011.

SCHAAFSMA, I. S.; SOPHIE, T. B.; ZUIDHOF, A. B.; ZAAGSMA, J.; MEURS, H. The inhaled Rho kinase inhibitor Y-27632 protects against allergen-induced acute bronchoconstriction, airway hyperresponsiveness, and inflammation. American Journal of Physiology - Lung Cellular and Molecular Physiology, v. 295, p. 214-219, 2007

SCHMIDT, P. The 2012 hormone therapy position statement of the North American menopause Society. Menopause, v. 19, p. 257-271, 2012.

SCHMIDT, J., FLEIBNER, S., HEIMANN-WEITSCHAT, I., LINDSTAEDT, R.; SZELENYI, I. The effect of different corticosteroids and cyclosporin A on interleukin-4 and interleukin-5 release from murine TH2-type T-cells. European Journal of Pharmacology, v. 260, p. 247-250, 1994.

SCHUIJS, M. J.; WILLART, M. A.; HAMMAD, H.; LAMBRECHT, B. N. Cytokine targets in airway inflammation. Current Opinion of Pharmacology, v. 3, p. 351-361, 2013.

SCHUSTER, D. P. What Is Acute Lung Injury? What is ARDS? Chest, v. 107, p. 1721-1726, 1995.

SMITH, R. P.; DEWAR, J. A.; WINTER, J. H. Tamoxifen-induced asthma. Lancet, v. 20, p. 341- 347, 1993. 
SIROIS, M. G.; JANCAR, S.; BRAQUET, P.; PLANTE, G. E.; SIROIS, P. PAF increases vascular permeability in selected tissues: effect of BN52021 and L-655,240. Prostaglandins, v. 36, p. 631-44, 1988.

SMITH, K. 2011. Examination of vaginal smears in the rat. Disponível em: <http://oslovet.norecopa.no/teaching/rat/oestrus/>. Acesso em: 10 out. 2013.

SPEYER, C. L.; RANCILIO, N. J.; MCCLINTOCK, S. D.; CRAWFORD, J. D.; GAO, H.; SARMA, J. V.; WARD, P. A. Regulatory effects of estrogen on acute lung inflammation in mice. American Journal of Physiology and Cell Physiology, v. 288, p. 881-890, 2005.

SPORNITZ, U. M.; SOCIN, C. D.; DAVID, A. A. Estrous stage determination in rats by means of scanning electron microscopic images of uterine surface epithelium. The Anatomical Record, v. 254, p. 116-126, 1999.

STARLING, C. M.; PRADO C. M.; LEICK-MALDONADO, E. A.; LANÇAS, T.; REIS, F. G.; ARISTÓTELES, L. R.; DOLHNIKOFF, M.; MARTINS, M. A.; TIBÉRIO, I. F. Inducible nitric oxide synthase inhibition attenuates lung tissue responsiveness and remodeling in a model of chronic pulmonary inflammation in guinea pigs. Respiratory Physiology of Neurobiolology, v. 165, n. 2, p. 185-194, 2009.

TAM, A.; MORRISH, D.; WADSWORTH, S.; DORSCHEID, D.; PAUL MAN, S. F. AND SIN, D. The role of female hormones on lung function in chronic lung diseases. BMC Women, v. 110, p. 11-24, 2011.

TAKEDA, M.; TANABE, M.; ITO, W.; UEKI, S.; KONNNO, Y.; CHIHARA, M.; ITOGA, M.; KOBAYASHI, Y.; MORITOKI, Y.; KAYABA, H.; CHIHARA, J. Gender Difference in Allergic Airway Remodeling and Immunoglobulin Production In Mouse Model of Asthma. Respirology, v. 18, n. 5, p. 797-806, 2013.

TAVARES DE LIMA, W.; TEIXEIRA, C. F. P.; SIROIS, P.; JANCAR, S. Involvement of Eicosanoids and PAF in immune-complex alveolitis. Journal of Medicine and Biology Research, v. 22, p. 745-748, 1989.

TAVARES DE LIMA, W.; STEIL, A. A.; RUSSO, M.; STAROBINAS, N.; TEIXEIRA, C. F.; JANCAR, S. Lipid mediators, tumor necrosis factor and nitric oxide and their interactions in immune-complex-induced lung injury. European Journal of Pharmacology, v. 358, p. 69-75, 1998.

THOMAS, P. S.; YATES, D. H.; BARNES, P. J. Tumor necrosis factor- $\alpha$ increases airway responsiveness and sputum neutrophils in normal human subjects. American Journal Respire Critical Care Medicine, v. 152, p. 76-80, 1995.

TICCONI, C.; PIETROPOLLI, A.; PICCIONE E. Estrogen replacement therapy and asthma. Pulmonary Pharmacology Therapy, v. 13, p. 169-172, 2013.

TOGBE, D.; SCHNYDER-CANDRIAN, S.; SCHNYDER, B.; DOZ, E.; NOULIN, N.; JANOT, L.; SECHER, T.; GASSE, P.; LIMA, C.; COELHO, F. R.; VASSEUR, V.; ERARD, F.; RYFFEL, B.; COUILLIN, I.; MOSER, R. Toll-like receptor and tumour necrosis factor 
dependent endotoxin-induced acute lung injury. International Journal of Experimental Pathology, v. 88, p. 387-391, 2007.

TOWNSEND, E. A.; SATHISH, V.; THOMPSON, M. A.; PABELICK, C. M.; PRAKASH, Y. S. Estrogen effects on human airway smooth muscle involve cAMP and protein kinase A. American Journal of Physiology and Lung Cell Molecular Physiology, v. 303, n. 10, p. 923-928, 2012.

TRINDADE, S. H.; JÚNIOR, J. F.; LORENZI-FILHO, G.; MACCHIONE, M.; SALDIVA, P. H. Methods for Studying Mucociliary Transport. Revista Brasileira de Otorrinolaringologia, v. 73, n. 5, p. 704-712, 2007.

TROISI, R. J.; SPEIZER, F. E.; WILLETT, W. C.; TRICHOPOULOS, D.; ROSNER, B. Menopause, postmenopausal estrogen preparations, and the risk of adult-onset asthma. A prospective cohort study. American Journal of Respiratory Critical Care Medicine, v. 152 , p. 1183-1188, 1995.

VÉLEZ-ORTEGA, A. C.; TEMPRANO, J.; RENEER, M. C.; ELLIS, G. I.; MCCOOL, A.; GARDNER, T.; KHOSRAVI, M.; MARTI, F. Enhanced generation of suppressor T cells in patients with asthma taking oral contraceptives. Journal of Asthma, n. 50, v. 3, p. 223-230, 2013.

WANG, D. W.; ZHOU, R. B.; YAO, Y. M.; Role of cholinergic anti-inflammatory pathway in regulating host response and its interventional strategy for inflammatory diseases. Chineese Journal of Traumatology, v. 12, n. 6, p. 355-364, 2009.

WEIHUA, Z.; SAJI, S.; KINEN, S. M.; CHENG, G.; JENSEN, E. V.; GUSTAFSSON, J. A. Estrogen receptor (ER) b, a modulator of ERa in the uterus. Proceedings of the National Academy Science, v. 97, n. 11, p. 936-941, 2000.

WENZEL, S. E. Asthma phenotypes: the evolution from clinical to molecular approaches. Nature Medicine, v. 18, n. 4, p. 716-725, 2012.

WOOD, G. A.; FATA, J. E.; WATSON, K. L.; KHOKHA, R. Circulating hormones and estrous stage predict cellular and stromal remodeling in murine uterus. Reproduction, v. 133, p. 1035-1044, 2007.

ZHANG, Y.; LAMM, W. J.; ALBERT, R. K.; CHI, E. Y.; HENDERSON, W. R.; LEWIS, D. $B$. Influence of the route of allergen administration and genetic background on the murine allergic pulmonary response. American Journal of Respiratory Critical Care Medicine, v. 155, n. 2, p. 661-669, 1997.

ZHAO, Y.; KOGA, K.; OSUGA, Y.; IZUMI, G.; TAKAMURA, M.; HARADA, M.; HIRATA, T.; HIROTA, Y.; YOSHINO, O.; INOUE, S.; FUJII, T.; KOZUMA, S. Cyclic stretch augments production of neutrophil chemokines and matrix metalloproteinases-1 (MMP-1) from human decidual cells, and the production was reduced by progesterone. American Journal of Reproduction Immunology, v. 69, n. 5, p. 454-462, 2013. 
ZIMMERMAN, J. L.; WOODRUFF, P. G.; CLARK, S.; CAMARGO, C. Relation between phase of menstrual cycle and emergency department visits for acute asthma. American Journal of Respiratory Critical Care Medicine, v. 162, p. 512-515, 2000. 